\title{
Mobile Services for Green Living
}

Diego Pajarito Grajales Doctoral Thesis

$\varphi: 39^{\circ} 59^{\prime} 37.78^{\prime \prime} \mathrm{N}$ $\lambda: 0^{\circ} 4^{\prime} 25.18^{\prime \prime} \mathrm{W}$

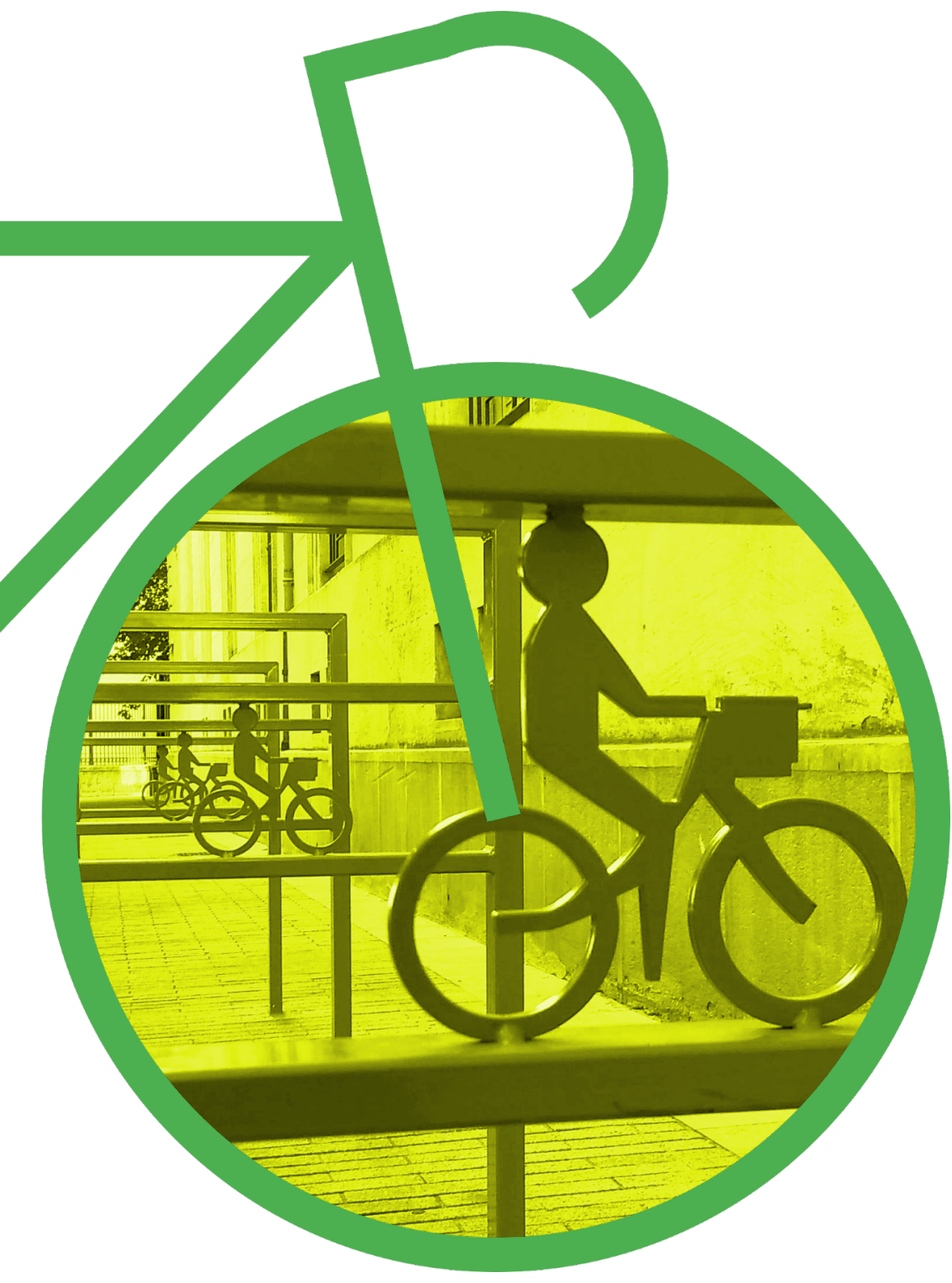

Supervised by:

Michael Gould Christian Kray Tiago Oliveira 



\section{Mobile Services For Green Living}

Dissertation submitted by Diego Pajarito Grajales to apply for the joint doctorate degree from the Universitat Jaume I, Universidade Nova de Lisboa and Westfälische Wilhelms-Universität Münster.

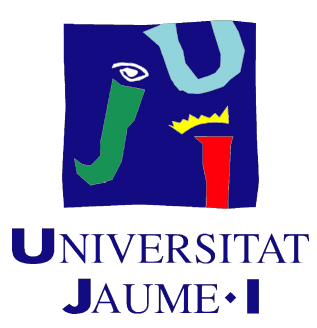

\section{European Joint Doctorate Marie Skłodowska-Curie in Geoinformatics}

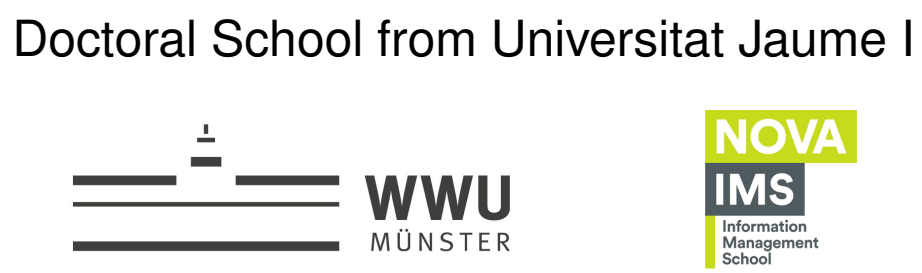

\section{Diego Pajarito Grajales}

\section{Supervisors:}

Dr. Michael Gould

(Universitat Jaume I)
Dr. Christian Kray

(Westfälische Wilhelms-Universität Münster)
Dr. Tiago Oliveira

(Universidade Nova de Lisboa)

Castelló de la Plana (Spain), November 2018 


Agreement num. 642332 - GEO-C - H2020-MSCA-ITN-2014. 

A Violeta y Daniel 



\section{Acknowledgements}

I want to thank my two children, VIOLETA and DANIEL, whom not only cheered for me every night but also bravely resisted this long time away from me. I also want to acknowledge Carolina's time, patience and pieces of advice when this $\mathrm{PhD}$ was more a bunch of desires than reality. I gratefully thank my parents Gloria and Iznardo who taught me to pursue my dreams. Also, to all my friends (a long list of folks only possible after an unfair selection which I prefer to avoid) who always had kind words and good desires for me.

I want to especially acknowledge my supervisors which significantly supported me during the PhD and the manuscript writing. Thanks to Prof. Dr Michael Gould who not only backed most of my crazy ideas but also encouraged me to provide clear and understandable research outcomes. Also, thanks to Prof. Dr Christian Kray who made me part of his lab during my great time in Münster. I acknowledge the contributions of all other professors, researchers, and reviewers who kindly helped me to improve my research skills.

For all my Geo-C mates which made this time unforgettable but especially for those who helped me get over that all these small drawbacks: Ana, Manuel, Mehdi, Khoi and Fercho, only have the best wishes for the coming time. See you guys soon!!. To all cycling friends who I have met during this time, thanks for sharing the pleasure of riding a bicycle.

I gratefully acknowledge funding from the European Union through the GEOC project (H2020-MSCA-ITN-2014, Grant Agreement Number 642332, http:// www.geo-c.eu); from the Citizen Science COST Action CA15212 www.cs-eu.net; and from the bursary provided by the Association of Geographic Information Laboratories in Europe - AGILE for gathering research data. I also acknowledge collaboration from the cyclists associations Castelló en Bici, B.A.G. Malta, and Critical Mass MS. 



\section{Abstract}

Urban cycling is a sustainable transport mode that many cities are promoting. However, few cities are taking advantage of geospatial technologies to represent and analyse behavioural patterns and barriers faced during cycling. This thesis is within the fields of geoinformatics and serious games, and the motivation came from our desire to help both citizens and cities to better understand cyclist behaviour and mobility patterns. We attempted to learn more about the impact of gamified strategies on engagement with cycling, the reasons for choosing between mobile cycling applications and the way such applications would provide commuting information. Furthermore, we explored the potential benefits of offering tools to build decision-making for mobility more transparent, to increase cycling data availability, and to analyse commuting patterns. In general, we found our research useful to enhance green living actions by increasing citizens' willingness to commute by bicycle or communicating cycling conditions in cities.

For urban cycling, data coming from mobile phones can provide a better assessment and enrich the analysis presented in traditional mobility plans. However, the diversity of current mobile applications targeting cyclists does not provide useful data for analysing commuter (inner-city, non-sporting) cycling. Just a few cyclists are adopting these applications as part of their commuting routine, while

on the other hand cities are lacking a valuable source of constantly updated cycling information helpful to understand cycling patterns and the role of bicycles in urban transport.

This thesis analyses how the incentives of location-based games or geo-games might increase urban cycling engagement and, through this engagement, crowdsource cycling data collection to allow cities to better comprehend cycling patterns. Consequently, the experiment followed a between-groups design to measure the impact of virtual rewards provided by the Cyclist Geo-c application on the levels of 
intention, satisfaction, and engagement with cycling. Then, to identify the frictions which potentially inhibit bicycle commuting, we analysed the bicycle trips crowdsourced with the geo-game. Our analysis relied on a hexagonal grid of 30-metre cell side to aggregate trip trajectories, calculate the friction intensity and locate the frictions.

The thesis reports on the results of an experiment which involved a total of 57 participants in three European cities: Münster (Germany), Castelló (Spain), and Valletta (Malta). We found participants reported higher satisfaction and engagement with cycling during the experiment in the collaboration condition. However, we did not find a significant impact on the participants' worldview when it comes to the intentions to start or increase cycling. The results support the use of collaboration-based rewards in the design of game-based applications to promote urban cycling. Furthermore, we validated a procedure to identify not only the cyclists' preferred streets but also the frictions faced during cycling analysing the crowdsourced trips. We successfully identified 284 places potentially having frictions: 71 in Münster, Germany; 70 in Castelló, Spain; and 143 in Valletta, Malta. At such places, participants recorded trip segments at speeds below 5 $\mathrm{Km} / \mathrm{h}$ indicating a deviation from a hypothetical scenario with a constant cycling speed.

This thesis encompasses the cyclist and city perspectives of offering virtual incentives in geo-games and crowdsourcing cycling data collection to better comprehend cycling conditions in cities. We also compiled a set of tools and recommendations for researchers, practitioners, mobile developers, urban planners and cyclist associations interested in fostering sustainable transport and the use of bicycles.

Keywords: urban cycling, mobile, gamification, geoinformatics, frictions, incentives. 


\section{Resumen}

El ciclismo urbano es un modo de transporte sostenible promovido por muchas ciudades, sin embargo, son pocas las que aprovechan las tecnologías geoespaciales para representar o analizar los patrones de comportamiento y las barreras que enfrentan los ciclistas. Esta tesis combina elementos de geo-informática y juegos serios o formativos para ayudar a las ciudades y la ciudadanía a entender mejor el comportamiento de los ciclistas y los patrones de movilidad. De esta forma se busca mejorar la comprensión del impacto que tienen estrategias basadas en juegos sobre la adopción del ciclismo urbano, las razones que llevan a elegir entre una u otra aplicación móvil para ciclistas y la forma en que estas aplicaciones generan información sobre los desplazamientos de personas. Además, se exploran los beneficios de ofrecer herramientas que hacen más transparente la toma de decisiones de movilidad, generan datos sobre ciclismo urbano y mejoran el análisis de patrones de desplazamiento. En general, los resultados de esta investigación podrían ayudar a incrementar la adopción de estilos de vida amigables con el ambiente debido a una mayor intención de desplazarse en bicicleta por la ciudad y una mejor explicación del entorno ciclista en las ciudades.

Para el ciclismo urbano, los datos capturados mediante teléfonos móviles pueden mejorar las estimaciones y enriquecer el análisis presente en los planes de movilidad tradicionales. Sin embargo, la diversidad de aplicaciones móviles para ciclistas aún no provee la información necesaria para analizar los desplazamientos de ciclistas (con propósito de transportarse) dentro de la ciudad en bicicleta. Solo unos pocos ciclistas usan dichas aplicaciones de manera rutinaria mientras, por otro lado, las ciudades demandan una fuente de información constante y actualizada que ayude a entender los patrones de movilidad y el rol de las bicicletas dentro del transporte urbano.

Esta tesis analiza cómo los incentivos que ofrecen los juegos basados en local- 
ización o geo-juegos podrían incrementar el ciclismo urbano y, a través de su uso, recolectar información descentralizada para ayudar a las ciudades a entender los patrones de movilidad en bicicleta. Es así cómo se diseñó un experimento de comparación entre grupos para medir el impacto de las recompensas virtuales ofrecidas por el geo-juego "Ciclista Geo-C" en la intención, satisfacción y práctica del ciclismo urbano. Posteriormente, para identificar las fricciones que potencialmente restringen el ciclismo urbano, se analizaron los viajes en bicicleta recolectados por los participantes. Dicho análisis se soportó en una grilla hexagonal, con celdas de 30 metros de lado, para agregar los viajes, calcular la intensidad de las fricciones y su ubicación dentro de las zonas urbanas.

La tesis presenta los resultados del experimento que involucró 57 participantes en tres ciudades europeas: Muenster (Alemania), Castellón (España) y Valeta (Malta). Allí los participantes reportaron mayores niveles de satisfacción y motivación para usar la bicicleta con propósitos de transporte, sin embargo, no se encontró un impacto significativo en la percepción global del ciclismo en términos de intenciones de comenzar a usar o aumentar el uso de la bicicleta. Los resultados favorecen el uso de incentivos basados en colaboración entre participantes para promover el ciclismo urbano, además, permiten validar un procedimiento para identificar las calles preferidas para ir en bicicleta, así como los sitios con fricciones que potencialmente restringen el ciclismo. Se identificaron satisfactoriamente 284 lugares con potenciales fricciones: 71 en Muenster, 70 en Castellón y 143 en Valeta. En dichos lugares, los participantes grabaron segmentos de viaje con velocidades inferiores a $5 \mathrm{Km} / \mathrm{h}$, lo cual indicaba un comportamiento diferente al esperado con una velocidad constante al ir en bicicleta.

Esta tesis presenta las perspectivas del ciclista y las ciudades sobre cómo las recompensas virtuales, ofrecidas por geo-juegos, y la recolección descentralizada de datos de ciclismo ayudan a comprender el ambiente ciclista en las ciudades. Además compila un conjunto de herramientas y recomendaciones para investigadores, expertos, planificadores urbanos, desarrolladores de aplicaciones móviles y activistas interesados en promover el transporte sostenible y el uso de las bicicletas en ciudades.

Palabras clave: ciclismo urbano, teléfonos móviles, juegos serios, geo-informática, fricciones, incentivos. 


\section{Resum}

El ciclisme urbà és una manera de transport sostenible promogut per moltes ciutats, però poques d'aquestes aprofiten les tecnologies geo-espacials per a representar $\mathrm{o}$ analitzar els patrons de comportament $\mathrm{i}$ les barreres que es troben els ciclistes. Aquesta tesi combina la geoinformàtica i els jocs seriosos o formatius per ajudar a les ciutats i la ciutadania a entendre el comportament dels ciclistes $\mathrm{i}$ els patrons de mobilitat. La tesi pretén estendre el coneixement de l'impacte de les estratègies basades en jocs amb l'adopció del ciclisme urbà, les raons que porten a triar entre l'oferta d'aplicacions mòbils per a ciclistes i la forma en què aquestes aplicacions generen informació sobre els desplaçaments de les persones. A més, en aquesta tesi s'exploren els beneficis d'oferir eines que fan la presa de decisions de mobilitat més transparent, incrementen la quantitat de dades sobre ciclisme urbà i milloren l'anàlisi de patrons de desplaçament. En general, aquesta investigació és útil per promoure estils de vida sostenibles mitjançant una major intenció de desplaçar-se en bicicleta per la ciutat o una millor comunicació de l'entorn ciclista a les ciutats.

Per al ciclisme urbà, les dades capturades mitjançant telèfons mòbils poden millorar les estimacions i enriquir l'anàlisi present en els plans de mobilitat tradicionals. Tanmateix, la diversitat d'aplicacions mòbils per a ciclistes no proveeix informació útil per analitzar els desplaçaments dins de la ciutat (sense el propòsit de fer esport) amb bicicleta. Només uns pocs ciclistes fan servir aquestes aplicacions de forma contínua mentre, d'altra banda, les ciutats demanen aquesta font d'informació constant i actualitzada que ajudaria a entendre els patrons de mobilitat i el paper de les bicicletes en el transport urbà.

Aquesta tesi analitza com els incentius oferts per jocs basats en localització o geojocs podrien incrementar el ciclisme urbà i, a través del seu ús, recol-lectar informació descentralitzada sobre ciclisme per ajudar a les ciutats a entendre els 
patrons de mobilitat. D'aquesta manera, es proposa un experiment entre grups per a mesurar l'impacte de les recompenses virtuals ofertes pel geojoc "Ciclista Geo-C" amb la intenció, satisfacció i pràctica del ciclisme urbà. Posteriorment, per identificar les friccions que potencialment restringeixen el ciclisme urbà, es van analitzar els viatges amb bicicleta recol-lectats pels participants mitjançant el geojoc. Aquesta anàlisi es va suportar en una xarxa (graella) hexagonal, amb cel-les de 30 metres d'ample, es van agregar els viatges, es va calcular la intensitat de les friccions i es van localitzar dins de les zones urbanes.

La tesi presenta els resultats de l'experiment que va involucrar 57 participants en tres ciutats europees: Münster (Alemanya), Castelló (Espanya) i Valletta (Malta). Els participants van reportar major satisfacció i motivació per utilitzar la bicicleta per a transportar-se, però, no es va trobar un impacte significatiu en la perspectiva global del ciclisme quan es refereix a les intencions d'iniciar o augmentar l'ús de la bicicleta. Els resultats afavoreixen l'ús d'incentius relacionats amb la col·laboració entre participants per a promoure el ciclisme urbà, a més, permeten validar el procediment per identificar els carrers preferits per anar amb bicicleta així com les friccions que limiten el ciclisme. Es van identificar satisfactòriament 284 llocs amb potencials friccions: 71 a Münster, 70 a Castelló i 143 a Valletta. En aquests llocs, els participants van reportar segments de viatge amb velocitats inferiors als $5 \mathrm{~km} / \mathrm{h}$, la qual cosa, indicava un comportament diferent de l'esperat amb una velocitat constant al anar en bicicleta.

Aquesta tesi aporta la perspectiva del ciclista i les ciutats de com les recompenses virtuals en els geojocs i la recol-lecció descentralitzada de dades de ciclisme ajuden a comprendre l'ambient ciclista a les ciutats. A més compila un conjunt d'eines i recomanacions per a investigadors, experts, planificadors urbans, desenvolupadors d'aplicacions mòbils i activistes interessats a promoure el transport sostenible i l'ús de les bicicletes a les ciutats.

Palabras clave: ciclisme urbà, telèfon mòbil, jocs seriosos, geo-informàtica, friccions, incentius. 


\section{Index}

Abstract v v

Resumen vii

Resum ix

Acronyms xix

1 Introduction 1

1.1 Statement of the problem . . . . . . . . . . . . . . . 4

1.2 Research questions $\ldots \ldots \ldots \ldots \ldots \ldots$

1.3 Contributions of the thesis $\ldots \ldots \ldots \ldots \ldots$

1.4 Contribution to the Open City Toolkit - OCT $\ldots \ldots \ldots \ldots$

1.5 Related work . . . . . . . . . . . . . . . . . . . . 8

1.5.1 Urban cycling and information technologies . . . . . . . 8

1.5 .2 Urban cycling and data analysis . . . . . . . . . . 10

1.6 Thesis structure $\ldots \ldots \ldots \ldots \ldots \ldots$

$\begin{array}{lll}2 & \text { Methodology } & 15\end{array}$

2.1 Literature Review . . . . . . . . . . . . . . . . . . . . . . . 16

2.2 Experimental design . . . . . . . . . . . . . . . 20

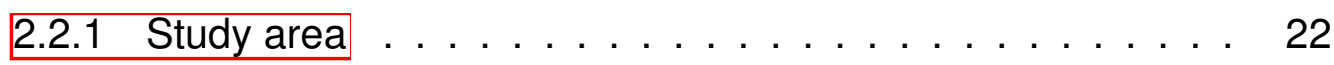

2.2 .2 Participants recruitment . . . . . . . . . . . . . . . 23

2.2 .3 Pre and post questionnaires . . . . . . . . . . . . 23

2.2 .4 The Cyclist Geo-C geo-game . . . . . . . . . . . . . 25 
2.3 Data $\ldots \ldots \ldots \ldots \ldots \ldots$

2.4 Estimating the impact of incentives on urban cycling . . . . . . . 28

2.5 Identifying frictions inhibiting bicycle commuting . . . . . . . . . . 29

2.6 Open cities and geo-analysis of urban cycling . . . . . . . . . 32

2.7 Summary . . . . . . . . . . . . . . . . . . . . . . . 33

3 Mobile technologies for urban cycling $\quad 35$

3.1 Literature review of cycling related research . . . . . . . . . . 36

3.1 .1 Research on Urban Cycling . . . . . . . . . . . . . . . . . 39

3.1.2 The four trends on cycling related research . . . . . . . . 41

Gamified platform design . . . . . . . . . . . . . . . 41

Experiments with gamified tools . . . . . . . . . . . . 42

Behavioural change strategies . . . . . . . . . . . 43

Data collection . . . . . . . . . . . . . . . . 44

3.1.3 Geospatial technologies for urban cycling . . . . . . . . . 45

3.2 The impact of incentives on participants . . . . . . . . . . . 46

3.2 .1 Participants profile . . . . . . . . . . . . . . . . . 47

3.2 .2 Participants bicycle trips . . . . . . . . . . . . . 50

3.2 .3 Intention to cycle . . . . . . . . . . . . . . . . . . 50

3.2 .4 Satisfaction with cycling . . . . . . . . . . . . . . . . 51

3.2 .5 Engagement with cycling during the experiment . . . . . 53

3.2 .6 Enjoyment with collaboration and competition . . . . . . . 55

3.3 Summary . . . . . . . . . . . . . . . . . . . . . . . 56

4 Identifying frictions inhibiting bicycle commuting 57

4.1 Cities and Urban cycling information . . . . . . . . . . . 58

4.2 Frictions inhibiting bicycle commuting . . . . . . . . . . 61

4.3 Spatial distribution of frictions . . . . . . . . . . . . . . . . 65

4.4 Bicycle paths and bicycle commuting . . . . . . . . . . . . . 69

4.5 Summary . . . . . . . . . . . . . . . . . . . . . . 75

5 Benefits of cycling data and geospatial analysis for open cities $\quad 77$

5.1 Encouraging bicycle commuting through mobile devices . . . . . 79 
5.1.1 Advantages of collaboration-based rewards for encouraging bicycle commuting . . . . . . . . . . . . . . 8 80

5.1 .2 Providing a geospatial context to urban cyclists . . . . . . . 81

5.1.3 Lessons learned from urban cyclists crowdsourcing bicycle

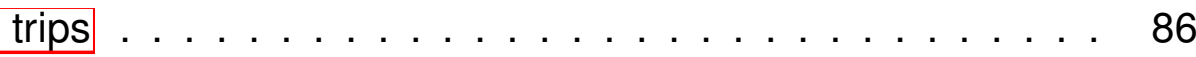

5.2 The spatial footprint of participants' profiles . . . . . . . . . . 88

5.2.1 Participants' reaction to bicycle paths and cycling applications 89

5.2 .2 Spatial distribution of trips . . . . . . . . . . . . . . . . 94

5.2 .3 Summary $\ldots \ldots \ldots \ldots$. . . . . . . . . . . . 96

6 Conclusion $\quad 99$

6.1 Summary of the thesis outcomes . . . . . . . . . . . . . . . . 99

6.1 .1 Contributions to future open and smart cities . . . . . . . 101

6.1 .2 Technical outcomes of the thesis . . . . . . . . . . . 101

6.2 Limitations . . . . . . . . . . . . . . . . . . . . . . . 102

6.3 Recommendations and future work . . . . . . . . . . . . 103

\begin{tabular}{ll}
\hline A Publications & 107
\end{tabular}

B Pre and Post Questionnaires 109

\begin{tabular}{ll}
\hline C Bicycle trips data structure & 123
\end{tabular} 



\section{Index of tables}

1.1 List of applications for cyclists with more than 10,000 downloads. . 12

2.1 Structure of the description table. . . . . . . . . . . . . . . . 19

2.2 Independent and dependent variables of the experiment. . . . . . 21

2.3 Questions for the cycling profile. . . . . . . . . . . . . . . . 24

2.4 List of tags in the "Cyclist Geo-C" geo-game. . . . . . . . . . . . . 29

2.5 Variables calculated during the study. . . . . . . . . . . . . 30

3.1 Demographic information of participants. . . . . . . . . . . . 47

3.2 Participants' cycling profile. . . . . . . . . . . . . . . . . . . . 49

3.3 Comparison of intentions to cycle before and after the experiment. 51

3.4 Top 20 Tags and Frequency. . . . . . . . . . . . . . . . . 53

5.1 Gender comparison of cycling distances and speed. . . . . . . . 90

5.2 Differences between participants depending on whether they used cycling apps. . . . . . . . . . . . . . . . 93 

xvii

\section{Index of figures}

1.1 Thesis scope and contribution. . . . . . . . . . . . . 6

2.1 Research methodology. . . . . . . . . . . . . . . . . . . 17

2.2 Keywords, Search focus, and expression. . . . . . . . . . . . 18

2.3 Experimental design. . . . . . . . . . . . . . . . . . . . . 22

2.4 Application interface for the two conditions. . . . . . . . . . . 25

2.5 Application high-level architecture. . . . . . . . . . . . . . 26

2.6 Trip and trips segments at a grid cell, two scenarios. . . . . . . . . 31

3.1 Concept interest based on web search. . . . . . . . . . . . 36

3.2 Book Chapters, Journal and Conference Papers reviewed. . . . . . 37

3.3 Distribution of publications through selected years. . . . . . . . . . 38

3.4 Reviewed publications related to cycling. . . . . . . . . . . . . 40

3.5 Publications reporting on gamification and motivation. . . . . . . . 41

3.6 Modes of transport used by participants in the city. . . . . . . . 48

3.7 Participants perception of cycling in the three cities. . . . . . . . 49

3.8 Tags recorded during the experiment and sentiment polarity. . . . 52

3.9 Measure of engagement by city and group. . . . . . . . . . . 54

3.10 Enjoyment with the motivation driving rewards. . . . . . . . . . . 55

4.1 Hourly distribution of cycled distance per day of the week. . . . . . 62

4.2 Cycling segments and speed distribution during the day. . . . . . 63

4.3 Trips and segments per trip in the three cities. . . . . . . . . . . 64

4.4 Aggregated third level frictions intensity and size. . . . . . . . . . 64

4.5 Castelló. Bicycle trips, first and third level frictions. . . . . . . . . 66 
4.6 Münster. Bicycle trips, first and third level frictions. . . . . . . . 67

4.7 Valletta. Bicycle trips, first and third level frictions. . . . . . . . . 68

4.8 Four typical scenarios for third level frictions. . . . . . . . . . 70

4.9 Castelló. Cycled distance using bicycle paths. . . . . . . . . . . 71

4.10 Münster. Cycled distance using bicycle paths. . . . . . . . . . 72

4.11 Valletta. Cycled distance using bicycle paths. . . . . . . . . . . 73

4.12 Cycled distance, proportion per trip. . . . . . . . . . . . . . 74

4.13 Average cycling speed and bicycle paths. . . . . . . . . . . 74

5.1 Mobile gamified tools and geospatial analysis benefiting open cities. 78

5.2 Geospatial visualisation of cycling patterns and frictions. . . . . . 84

5.3 Data display examples from transport studies. . . . . . . . . . . . 85

5.4 Trip distribution by cycling speed and distance cycled on a bike path. 89

5.5 Cycling constraints and participants' perception of them. . . . . . . 91

5.6 Intention to use an app while cycling and recorded trips. . . . . . . 92

5.7 Participants' use of cycling applications and trips. . . . . . . . . 93

5.8 Recorded trips distribution by gender. . . . . . . . . . . . . . . . 94

5.9 Participants' trips depending on whether or not they use cycling apps. 95

5.10 Simplified visualisation of bicycle trips. . . . . . . . . . 96 


\section{Acronyms}

FUA Functional urban areas

GA Grid area

GIS Geographic information systems

GNSS Global navigation satellite system

GPS Global positioning systems

$\mathbf{H C l}$ Human-computer interaction

HFI High fiction intensity

IT Information technologies

LBS Location-based services

OECD Organisation for Economic Co-operation and Development

OCT Open city toolkit

OSM Open street map

SDGs Sustainable Development Goals

UN United Nations Organization

UMZ Urban morphological zones

VGI Volunteered geographic information 
The mapmakers of Majorca were the first to place Gengen (Goa), Meli (Mali), and Tembuch (Timbukto) in roughly accurate positions.

Abrahan Cresques, a Jey of Palma, was a foremost member of the Catalan school of cartographers ... "master of mappaemundi and compasses" - that is, a cartographer and instrument-maker. ... he felt qualified to take on an assignment from Charles $V$ of France to produce a new world map. In 1375, Cresques completed the famous Catalan Atlas.

The atlas, with its six brilliantly colored maps, combined the detail and accuracy of the portolan chart and the scope of the medieval mappamundi. Cresques apparently employed the best contemporary information. The atlas reflected a much improved conception of the peninsular shape of India, included some towns and rivers in China ... and depicted both the Blue and the White Nile. The shores of northern Europe were drawn with greater definition. Much more than previous portolan charts, the Catalan Atlas moved inland to show towns and rivers-and almost no mythical creatures.

... After more than a thousand years, people were learning how to make maps to be used. They were coming to realize that uninformed speculation was no substitute for careful observation. Gradually and not always to reliably, they were learning to transmit information, not theory, through maps.

... Gerald Crone said, "the Catalan cartographers of the fourteenth century threw off the bond of tradition and anticipated the achievements of the Renaissance."

The Mapmakers, John Noble Wilford 


\section{Chapter 1}

\section{Introduction}

This chapter introduces the scope of our research in the area of applied technology for transport sustainability, specifically, encouragement for citizens to use urban cycling as a key form of green living. It describes the extent of the problem and the research questions the thesis seeks to answer. It continues with the contributions of the thesis and describes contributions to the Open City Toolkit: a deliverable in the European Union-funded project of which this thesis is a part. Finally, it presents related research in the areas of urban cycling, information technologies and data analysis, and ends by presenting the chapter structure of the thesis.

Human mobility is a major concern around the world. Global issues resulting from the growth of the urban population to about 3.5 billion people led the United Nations to define and promote the Sustainable Development Goals (SDGs) in 2015. Among the list of goals is SDG 11 - "Make cities inclusive, safe, resilient and sustainable" - which directly refers to city development, while the two targets of "provision of sustainable transport systems" and "reduction of the impact of cities in air quality" (United Nations, 2015) influence the future of urban transport systems. Sustainable transport can refer to many modes, from light rail and other mass transit to walkability of cities and, of course, increasing the use of bicycles.

The high modal share of cycling before the car revolution (Oldenziel et al. 2015) and resurgence in cities like Copenhagen and Amsterdam comes mainly from positive user perception: people consider bicycles a key asset for mobility because of the simple and energy-efficient technology they represent, added to a low entry barrier to embrace cycling as a complementary mode of transport (Bonham and Johnson, 2015; Pucher and Buehler, 2017). The combination 
of UN efforts to encourage sustainable transport systems and ecological and health-related benefits for cities frame our interest in, first, creating and providing cycling information, and second, in better understanding cycling patterns in cities. Hopefully, the work done here will help move more people to commute by bicycle and will convince more cities to study cycling patterns.

The motivation for our research came from requirements of the EU project "Geo-C: enabling open cities" (Degbelo et al., 2016b a) and our desire to help both citizens and cities to better understand cycling behaviour and patterns. The study lies within the field of geoinformatics, and so mobile tools and spatial analyses would be created and tested, as part of the project's Open City Toolkit. Potential benefits for cities may be, for example, to make decision-making processes for mobility more transparent due to the data analysis, and, in general, to enhance actions for green living through improved cycling conditions and infrastructure. We are also motivated to learn more about the reasons for choosing between the existing mobile applications for cyclists and the way such applications would provide information about daily commuting routines. This might lead to a better design for future mobile gamified technologies providing finer crowdsourced data on bicycle trips and fuelling local solutions to improve the urban cycling environment.

Who cycles? Where? For what purposes? And why do more citizens not use bicycles to commute to work or study? In general, cities lack quality data to answer these questions. This thesis analyses how the incentives of gamified technologies (Deterding et al., 2011; Nicklas et al., 2001) might increase urban cycling engagement and, through this, can crowdsource cycling information to allow cities to better comprehend cycling patterns. In particular, we refer to locationbased games or geo-games which provide a geospatial context to both incentives and data collection (Schlieder et al., 2006; Ahlqvist and Schlieder, 2018). When beginning this study, we noticed a relatively low adoption of mobile geospatial technologies compared to the current range of hyper-connected mobile devices.

We analyse how the technology supporting general purpose cycling has changed slightly during recent decades, with small improvements in bicycle mechanics and comfort accessories, while information technology has had an enormous development with a huge variety of devices, sensors, interfaces, and so on. This research is therefore intended to address the existing research gap in the design of mobile gamified technologies when it comes to encouraging bicycle commuting, on the one hand, and understanding urban cycling patterns on the other. Such a research 
gap makes it more difficult to monitor and analyse bicycle commuting to generate cyclist-friendly environments and enable open and smart cities. The gap also affects citizens' awareness and eventual willingness to participate and collaborate in resolving urban challenges such as mobility, pollution, and overall quality of life.

We were aware of the difficulties of engaging people (non-cyclists) to use bicycles as a regular means of transport. At an individual level, bicycle riding in cities implies overcoming difficulties such as the physical effort of pedalling, adverse environmental conditions, exposure to aggressive car drivers, and negotiating with vehicles at complex junctions in the city, among others. However, when individuals manage to overcome these barriers (and as their peers also do) they become convinced of the benefits of cycling and usually adopt it as part of their daily routine (Pooley et al., 2011).

At city level, governments and advocacy groups increasingly encourage the use of bicycles despite the lack of cycling information which, therefore, limits the evaluation of past urban interventions (Garrard, 2015), site-specific cycling patterns (Boss et al., 2018), and restrictions inhibiting bicycle commuting (Orellana and Wachowicz, 2011; Tabares, 2017). Pro-cycling urban interventions, such as expanding cycle path networks, traffic calming and enabling spaces for pedestrians and cyclists, demand finer granularity of the data than the commonly used mobility indicators (Navarro et al., 2013). Apart from the previous considerations, the final decision on using bicycles for commuting strongly depends on adequately combining a mind-shift, stimuli and consistently favourable policies.

The data feeding cycling analysis could either come from an external provider or as crowdsourcing (self-collected data). Although there are opportunities to access crowdsourced data from mobile cycling applications, such as Strava or Endomondo, such datasets have usually restricted access, limited coverage, or lack representativity in specific areas (Boss et al., 2018). Bicycle-sharing companies also generate relevant cycling information (van Waes et al., 2018; Fishman et al., 2013) but, in addition to restrictions already described, such datasets focus mostly on origin-destination instead of the street-by-street focus of this thesis.

Even given the high mobile phone penetration in most cities, urban cyclists seem not to massively engage with mobile persuasive technologies (National Geospatial Advisory Committee, 2015). Mobile technologies still need to evolve to become reliable tools to support behavioural change towards sustainable mobility. Outside 
cities, the existing variety of mobile solutions for competitive and recreational long-distance cyclists already helped to increase the awareness of cycling benefits. Urban cycling promotion would benefit from focusing on alternative approaches other than emphasising cycling performance or competition between cyclists.

Information technologies not only enable communication between citizens, researchers and city managers; they also ensure higher accuracy, direct feedback, higher data volumes, and, therefore, potentially better analysis of current city dynamics (Gössling, 2018). For urban cycling, these aspects have been largely unexplored (Handy et al., 2014) and, consequently, our research aims to fill this gap by exploring the design of mobile technologies to engage citizens with bicycle commuting and the analysis of cycling patterns based on volunteered cycling information.

\subsection{Statement of the problem}

Urban citizens are uber-connected to mobile devices and companies like Amazon, Google and Apple therefore know where they are and whether they are walking, cycling or driving (Weigend, 2017). However, most cities still cannot access or do not take into account such data sources as a valid citizen perspective for policy-making. For urban cycling, data from mobile phones can provide a better assessment and enrich the analysis presented in traditional mobility plans. However, the diversity of current mobile applications targeting cyclists does not provide useful data for analysing commuter (inner-city, non-sporting) cycling. Cyclists are therefore not adopting these applications as part of their commuting routine, while on the other hand cities are lacking a valuable source of constantly updated cycling information which could be used to understand cycling patterns and the role of bicycles in urban transport. Thus, mobile gamified technologies can help to encourage behavioural changes towards more sustainable transport systems as a bottom-up approach (Handy et al., 2014).

To promote urban cycling, cities usually prefer traditional strategies based on posters, newspapers, magazines, TV ads and so on. Although information technologies support virtual social networks and mobile applications, very few focus on urban cyclists, offering limited functionalities or lacking coverage in certain cities.

The popular cycling mobile applications which are used are generally focus on 
extra-urban cycling performance, providing rider feedback with details such as cycling speed, cadence, or distance. Also, the kind of social interaction offered mainly delivers challenges to boost competition between users. This focus on sports performance seems not to fit with urban cyclists' interests. Bicycle efficiency in cities is more related to shorter trip times, flexibility to avoid congested or polluted areas, more route diversity, enjoyment and pleasure, among other factors.

In addition to the above, neither the existing cycling applications nor the typical city transport analysis include methods to geospatially identify and analyse the elements constraining the use of bicycles in cities. We therefore found a research gap in the lack of attention paid to geospatial technologies for supporting communication between cities, researchers and city managers, particularly in the design of mobile technologies for urban cyclists.

\subsection{Research questions}

Our research focused on the research gap in the design of mobile gamified technologies for encouraging bicycle commuting. Additionally, it aimed to enhance the geospatial analysis of cycling patterns in cities through mobile-generated datasets to support data-driven policy-making. This thesis sought to answer the following research questions:

- Q1: What are the frictions potentially preventing citizens from bicycle commuting? Where and when do they occur?

- Q2: How might collaboration and competition-based incentives (presented in mobile applications) affect urban cycling?

- Q3: How can geospatial analysis of crowdsourced bicycle trip data help us understand urban cycling patterns and improve the cycling environment?

\subsection{Contributions of the thesis}

The contributions of the thesis were intended to address the existing research gap in the design of mobile gamified technologies to not only encourage bicycle commuting but also to understand cycling patterns. Figure 1.1 shows how our research fills the gap in the interaction between citizens and cities when it comes 
to adopting of bicycle commuting as a key form of green living. Commuters are a kind of citizen who are willing to move across the city using the most convenient means of transport. In the case of bicycle commuters, they use a flexible and environmentally friendly mode of transport which strongly depends on the city atmosphere and which minimises potential frictions (Problem A).

Our approach also tackles the lack of connection between the popular cycling applications and the analysis of cycling mobility. Such platforms rarely analyse cycling patterns to provide insights into the city's cycling environments which consequently constrains decision-making (see problem B in Figure 1.1). The thesis experiments with a gamified cycling application to encourage cycling commuters to crowdsource cycling data collection trips (Experiment 1), and with geospatial analysis methods to help cities to prioritise urban interventions encouraging cycling mobility (Experiment 2).

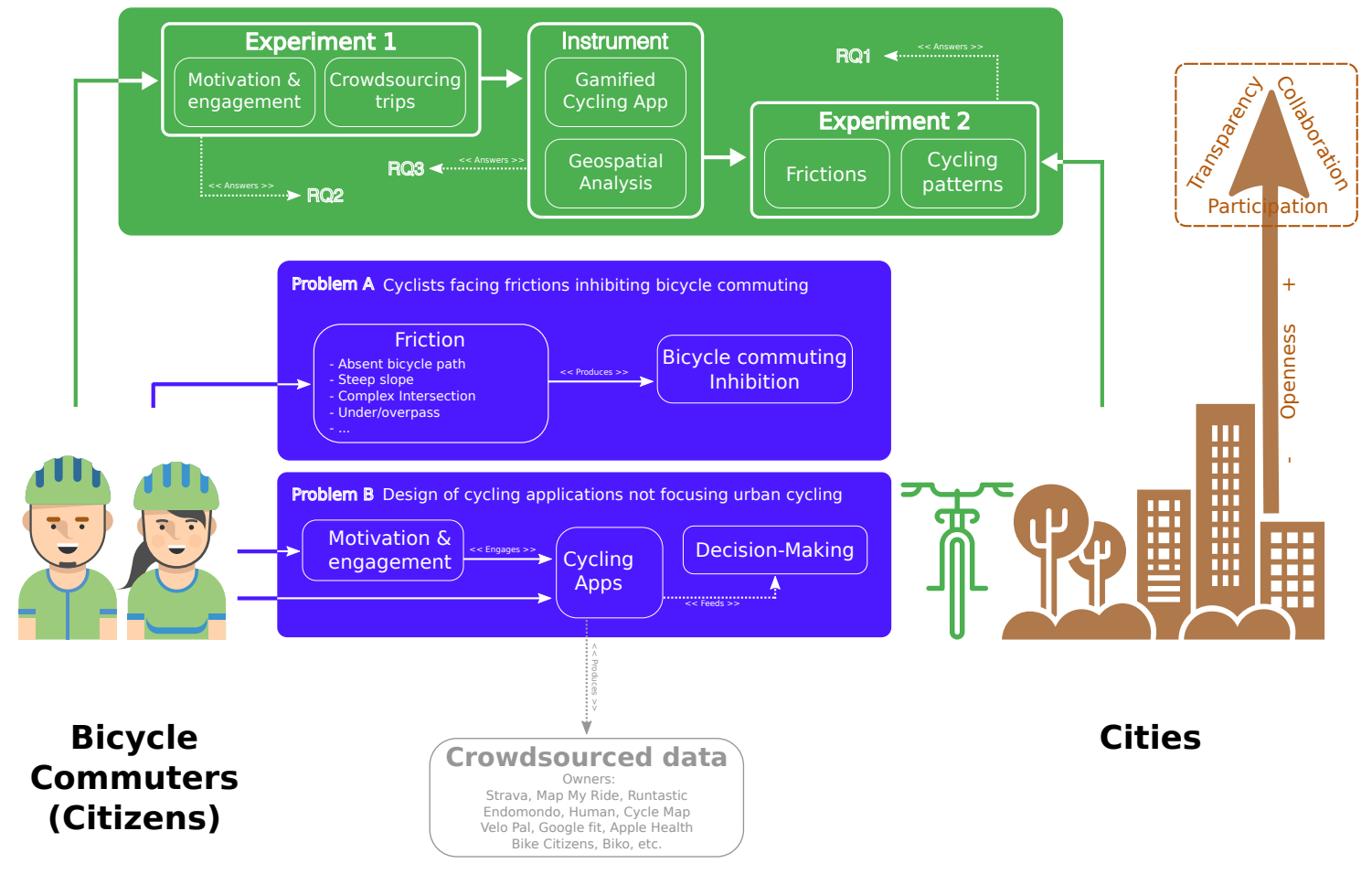

Figure 1.1: Thesis scope and contribution.

During the first experiment, we recruited approximately sixty participants in three European cities and crowdsourced 793 bicycle trips. We also obtained insights into the kind of interaction preferred by urban cyclists when it came to the gamified 
mobile applications. We show a slight preference for collaboration-based over competition-based rewards in urban cycling geo-games, which we think merits further research. The preference for collaboration coincides with the interest of urban cyclists in contributing to the development of a friendlier cycling environment and greener and more habitable cities.

In the second experiment, we identified and located 284 places with potential frictions inhibiting bicycle commuting, using participants' crowdsourced trip data. We also tested geospatial analysis tools to evaluate cycling patterns, describe how participants used cycle paths, and analysed the spatial footprint of the participants' profiles. The definition of "friction", together with the geospatial analysis needed to identify them, could complement traditional mobility studies. This new procedure would help policy-makers to understand cycling patterns from GPS tracks and gain insights into the city's cycling conditions.

This thesis compiled a set of tools and recommendations for researchers, mobile application developers, urban planners and cycling associations who might be interested in improving sustainable transport based on bicycles. Such a compilation has two main perspectives: from the cyclists' point of view, we found collaboration-based rewards motivating users to crowdsource bicycle trips through a gamified mobile application; from the city's perspective, we used geospatial analysis to aggregate crowdsourced bicycle trips, identify the potential frictions inhibiting bicycle commuting, and compare the cycling patterns of three European cities.

\subsection{Contribution to the Open City Toolkit - OCT}

In addition to the general research contribution, the thesis has produced reusable tools for cities, making a contribution to the Geo-C Open City Toolkit (OCT): aimed at compiling tools, services and applications to facilitate public participation and transparency. A literature review compiled a set of 140 scientific publications published between 2014 and 2017 related to the use of mobile devices for promoting cycling. We summarise the reviewed publications and the descriptors related to urban cycling in the form of a comparison table (Pajarito and Gould, 2017a). This public dataset allows future researchers to advance in this field and to expand the review of related publications reporting on pervasive and gamified technologies and to track the development of this research field. 
The mobile geo-game supporting our experiment allowed us to crowdsource cycling data collection by adopting an open architecture, making it a remarkable contribution to the OCT. The application is registered in the OCT catalogue, with the intention of providing a reusable and customisable tool for cities or advocacy groups wishing to collect cycling data, to integrate location-based services into existing applications and to evaluate alternative strategies for promoting urban cycling.

The set of anonymous bicycle trip data crowdsourced during our experiment is also an OCT contribution used for identifying cycling patterns and the location of potential frictions inhibiting bicycle commuting (Pajarito and Gould, 2018). This dataset will help researchers, data scientists or urban planners for future analyses or for comparison with similar datasets. Finally, the compilation of geospatial analysis procedures written in popular programming languages such as Python, $\mathrm{R}$ and SQL encompasses the final contribution to the OCT. Such code-based procedures and workflows describe the grid-based analysis, aggregation of trip segments, frictions identification, and cycling patterns visualisation used in the data preparation phase and the interpretation of the results of the experiments conducted in this thesis and described in detail in the coming chapters.

\subsection{Related work}

This section briefly describes the related research works considered during the study. The first subsection presents the research exploring the relationship between urban cycling and the use of information technologies in general, highlighting the use of mobile technologies to promote and advertise cycling benefits. The second subsection presents the research on data analysis to understand cycling patterns and describes the existing sources of cycling data.

\subsubsection{Urban cycling and information technologies}

Bicycles arrived in cities about two centuries ago and authorities in urban areas have adopted policies to regulate their use, with diverging results. While very few of these led to increasing the adoption of urban cycling, others produced a small increment in bicycles' modal share (Oldenziel et al., 2015). Apart from the outstanding usage of bicycles in cities such as Copenhagen (Nielsen et al., 2013) 
or Amsterdam (Pucher and Buehler, 2008), many other cities are fostering urban cycling without seeking a place in the global rankings for cycling adoption (Pucher) et al., 2010).

Due to the efficiency of bicycles in terms of use of space, fuel consumption and $\mathrm{CO} 2$ emissions (Handy et al., 2014), cities are beginning to invest substantial resources in attracting more citizens to cycling (Nielsen et al., 2013). The strategies mostly used are infrastructure-based, such as a broader cycle path networks (Pucher et al., 2010), parking facilities for bicycles (Garrard, 2015), and public bicycle-share systems (Pucher and Buehler, 2017). In addition, some other cities have fostered urban cycling by portraying it as a way to reduce pollution (Revi et al., 2014; Küster and Blondel, 2013), improve urban living conditions, or build greener cities (Pardo, 2018; Urry et al., 2017; Pucher et al., 2010).

The strategies for promoting urban cycling are diverse but tend to use similar communication media. They usually rely on traditional channels such as posters, billboards, conferences, or street events to show the benefits of cycling. Others rely on traffic-calming actions or other urban interventions boosting cycling such as temporary or permanent car banning (Urry et al., 2017; Topp and Pharoah, 1994). They may be shared (Wall et al., 2016), segregated (Xu et al., 2016), or exclusive (Bagloee et al., 2016) bicycle paths. As a compliment to this, some cities have launched mass events for cyclists, such as temporary car-free spaces, to set up a bicycle-friendly environment (Torres et al., 2013; Cervero et al., 2009).

Cycling enthusiast groups have emerged all over the world in the last few decades. These promote the use of bicycles worldwide, share their cycling experiences and preach the benefits of urban cycling for the environment and urban mobility (Tabares, 2017). The city of Amsterdam in 1970 had a well-documented case when active citizen participation demanded bicycle and pedestrian friendly development of the city, leaving positive consequences visible today (Oldenziel et al., 2015). Citizens demanding that the city stop building motor vehicle infrastructure and instead protect pedestrians, cyclists, and especially kids, shaped one of the most bicycle-friendly cities in the world and demonstrated the decisive role of the public in developing a cycling city (Garrard, 2015; Horton, 2006).

In the last few decades, cycling advocacy groups have lead "critical mass" events to protest and demand better cycling conditions worldwide (Carlsson, 2002). Although these events have been run in many cities, their successful influence strongly depends on sympathetic policy-makers and local authorities 
(Pucher et al., 2010). In some cases, these authorities lack access to urban cycling information (Gössling, 2018) and therefore struggle building new infrastructure or deploying campaigns to promote cycling due to their limited comprehension of the cycling environment.

Lastly, a growing trend is also changing the global cycling landscape. Bicyclesharing systems emerged and boosted urban cycling from a different bicycle ownership perspective (Fishman et al., 2013). Such a trend relies on the transportas-a-service concept and a business model which relieves users from buying, storing, or maintaining bicycles (Pucher et al., 2010; Gössling, 2018). Its success has come from the combined convenience of users and the perceived value for money, especially for new cyclists. However, most users of such systems move over from other sustainable modes rather than from their private car (Fishman et al., 2013; Campbell and Brakewood, 2017) and some of them cycle less than once a week (Médard de Chardon et al., 2017).

\subsubsection{Urban cycling and data analysis}

The favourable scenario in terms of public and government interest in urban cycling applies neither to information technologies for cyclists nor cycling data analysis. Cycling data is often unavailable and, in some cases, is either highly aggregated or over simplified for use in general transport surveys (Gössling, 2018). The contrasts between the growing adoption of cycling and poor data availability have motivated research on urban cycling within the current information sciences trend towards "open data" (Benitez-Paez et al., 2018; Degbelo et al., 2016a; Attard et al., 2016). Having high-quality information such as travel diaries, trip inventories, or GPS tracks can benefit both the analysis and promotion of cycling as well as the planning and evaluation of cycling infrastructure (Braun et al., 2016). Actors such as advocacy groups, government agencies and technology companies have therefore tested numerous alternatives for collecting cycling data using either mobile devices (Barratt, 2017) or other available location-based services (LBS) (Yeboah and Alvanides, 2015; Pooley et al., 2011).

Some of those attempts have used open-source platforms such as the Open Cycle Map (OpenStreetMap Contributors, 2017) or crowdsourcing initiatives such as Bike Maps Org (Boss et al., 2018; Nelson et al., 2015). However, these usually fail to achieve a critical mass of data volume or popularity of commercial 
solutions due to their reliance on particular niches (Yeboah and Alvanides, 2015; Sultan et al., 2017; Reddy et al., 2010). Nonetheless, the capabilities of mobile devices to collect data on a human scale are a key factor for evaluating suitable transportation and supporting volunteered data collection (Constantinidis, 2016; Goodchild, 2007). Additionally, the interest in empowering citizens and boosting bottom-up participation strategies lead to an increasing interest in the so-called citizen science, which for transport could potentially expand the alternatives for data collection and analysis (Haklay, 2013; Attard et al., 2016).

Identifying urban cyclists' preferences and the most cycled streets could facilitate data-driven policy to encourage cycling. Cities could decide where to improve cycling infrastructure (e.g., creating, expanding or relocating cycle paths); prioritising traffic calming such as car-free zones, bicycle priority streets, contraflow cycle lanes, or road diets; or enabling modal integration for cycling. The interest in identifying such preferences has motivated the development of technological solutions aiming to gather cycling information through mobile phones (Gössling, 2018; Norris, 2015; Claudel et al., 2015). Due to the commercial interests behind these solutions, they tend to adopt a data-centric business model that sells analysis services (Zeile et al., 2016; National Geospatial Advisory Committee, 2015).

Some technological solutions target the tracking of sporting activities (Wolff et al., 2017) and brands such as "Fitbit" offer wearable devices and a platform to manage sports information (Tomitsch and Haeusler, 2015), on the one hand, and "Strava" or "Endomondo" use social geo-located interaction to engage users with sports (Spillers and Asimakopoulos, 2014; Barratt, 2017) on the other. This trend goes towards more user-centred technology rather than one-size-fits-all solutions (Kingham and Tranter, 2015; Pejovic and Musolesi, 2015). Another interesting trend focuses on offering open access to raw data for visualisation, mobility analysis, or other yet-to-be-discovered uses within web services or apps. Cities and regional authorities seem not to exploit this data, or at least we did not find published reports of it.

So far, the focus of existing mobile applications and scientific research seems not to be in the direction of understanding cycling mobility or supporting urban decision-making. Such a conclusion comes from reviewing the mobile applications for cyclists having more than 10,000 downloads and available in app stores. We found just three apps focusing on urban bicycle trips: "Bike Citizens", "Map my Ride" and "Biko", whereas users of popular apps such as "Strava" and the others 
mainly recorded longer, extra-urban rides. Table 1.1 shows how mobile cycling applications mostly integrated competition-based rewards as their gamification strategy.

\begin{tabular}{l|c|c|c|c}
\hline & \multicolumn{2}{|c|}{ Type of cycling } & \multicolumn{2}{c}{ Gamification Strategies } \\
App Name & Urban & Sports & Collaboration & Competition \\
\hline Strava & & $\mathrm{X}$ & $\mathrm{X}$ & $\mathrm{X}$ \\
Map My Ride & & $\mathrm{X}$ & $\mathrm{X}$ & $\mathrm{X}$ \\
Runtastic & & $\mathrm{X}$ & & $\mathrm{X}$ \\
Endomondo & & $\mathrm{X}$ & & $\mathrm{X}$ \\
Human & & $\mathrm{X}$ & & $\mathrm{X}$ \\
Cycle Map & $\mathrm{X}$ & & & $\mathrm{X}$ \\
VeloPal & & $\mathrm{X}$ & & $\mathrm{X}$ \\
Google fit & & $\mathrm{X}$ & & $\mathrm{X}$ \\
Apple Health & & $\mathrm{X}$ & & $\mathrm{X}$ \\
Bike Citizens & $\mathrm{X}$ & & $\mathrm{X}$ & $\mathrm{X}$ \\
Biko & $\mathrm{X}$ & & & $\mathrm{X}$ \\
\hline
\end{tabular}

Table 1.1: List of applications for cyclists with more than 10,000 downloads.

Although most of the reviewed applications used gamification to engage users, we found two cycling studies which succeeded in engaging urban cyclists only by delivering instructions through the mobile phone. The first example recorded trips from more than 190 volunteer cyclists from 2009 to 2014 (Chen et al., 2018) only instructed to use the application "CycleTracks". The application focused only on bicycle trip recording and provided only trip details without any gamified strategy (Broach et al., 2012). The second example is the wireless network prototype for real-time social interaction for cyclists called "GreenBikeNet" which relied upon ZigBee technology (Abu-Sharkh and Dabain, 2016).

In general, there are multiple successful experiences of collaborative data collection campaigns such as the European mobility week (European Cyclist Federation, 2018), local cycling festivals (Fietsberaad Vlaanderen, 2016), or efforts from cycling associations (People for Bikes, 2017). Through these examples, we found organisations willing to understand urban cycling and cyclists contributing to cycling data collection which led to user-centred strategies to engage with bicycle commuting (te Brömmelstroet, 2014). 


\subsection{Thesis structure}

The remaining sections of this thesis continue as follows: Chapter Two describes the research methodology, procedures and tools used for the literature review and data collection. Continues with the experimental design and deployment, the analysis methods for identifying the preferred motivation when using geo-games, frictions inhibiting bicycle commuting and cycling patterns from crowdsourced cycling trips.

Chapter Three analyses the impact of incentive types on urban cycling and reviews the strategies applied by existing applications to engage users with cycling. It then presents the experiment deployment and findings on cyclists' preferred incentives when interacting with geo-games. Finally, it highlights participants feedback when crowdsourcing bicycle trips.

Chapter Four focuses on identifying the frictions inhibiting bicycle commuting. It reviews alternatives to gather cycling information through mobile technologies, presents the frictions identified for the cities of Castelló in Spain, Münster in Germany, and Valletta in Malta. It presents the participants' cycling patterns and the relationship with the existing cycling infrastructure.

Chapter Five discusses the results of the two experiments and the role of mobile services when it comes to the promotion of green living and especially urban cycling. It examines the effects of participants' background on cycling research and describes the lessons learned in recruiting urban cyclists to crowdsource bicycle trips. Finally, it presents the spatial footprint of the participants' profiles concerning the use of bicycle paths and cycling applications. This chapter integrally analyses the thesis contributions considering limitations and identifying the future research directions.

Chapter Six concludes with the guidelines to design pervasive mobile technologies for urban cyclists, the thesis outcomes, limitations and recommendations arising from this research. 



\section{Chapter 2}

\section{Methodology}

This chapter describes the research method and procedures applied during the research. The chapter first outlines the procedure to review publications reporting on the use of mobile applications and location-based services (LBS) to encourage and monitor cycling. Then, it presents the experimental design, recruiting procedure and tools used during the experimental phase. It also describes the methods to evaluate the impact of incentive types on urban cycling and to identify the frictions inhibiting bicycle commuting. Lastly, the chapter comments on our considerations during the general discussion as well as during the description of research contributions and future work.

To conceptually frame this thesis, we started with a literature review which aimed to learn the current state of research on the use of technology, particularly location-based applications, to encourage behavioural changes towards sustainable commuting using bicycles. Thus, we used search terms related to open cities, green living, mobility and gamification, to discover scientific publications reporting on these topics. Due to the fast and constant evolution of mobile technologies, we limited in time our review from 2014 to 2017 trying to avoid the effects produced by the fast obsolescence of older mobile technologies in our review. Such a review served as well to conceptually link our research with the concept of "citizen participation" and, therefore, to the three key challenges (i.e., improve transparency, facilitate participation, and ease collaboration) of open cities (Degbelo et al., 2016a b) in the GEO-C project.

For the case study, we considered commuting as a key activity which can impact citizens' quality of life (Mapes and Wolch, 2011; Kingham and Tranter, 2015) and 
cycling as one of the most environmentally friendly modes of transport available in cities; also quite popular nowadays (Pucher and Buehler, 2017). Moreover, due to the relevance of mobile technologies, we saw mobile phones as a convenient interaction tool for providing citizen feedback and conveying the message of cycling as a reliable option for commuting. Finally, we took into account the capabilities of serious games, and particularly geo-games, to engage people with certain activities, to enable interaction with the geographical environment, and to crowdsource geospatial data collection.

After defining the research scope, we defined three sequential phases shown in Figure 2.1. Firstly, there was a review of both literature and cycling applications and how such tools support urban cycling promotion. Secondly, the experimental phase which consisted of design, implementation of the mobile application, and deployment of the experiment. Lastly, the analysis phase which included the evaluation of the impact of incentive types on urban cycling and the identification of frictions inhibiting cycling commuting. This phase also included the development and/or application of statistical and spatial analysis tools to enhance the Open City Toolkit - OCT. In addition to that, the methodology involved the writing tasks for the research papers and thesis monograph.

\subsection{Literature Review}

This section describes the procedure applied to review literature reporting on the use of mobile applications, LBS and gamification to encourage and monitoring cycling. The review aimed to identify the research trends of integrating gamified strategies and mobile devices to study and promote urban cycling as well as the research gaps in the field. The review concepts were part of our definition of "smart mobility" as the use of technology to improve sustainable transport, especially urban cycling.

The review consisted in four tasks: a concept based search on four repositories (SpringerLink, ScienceDirect, IEEE Xplore and Scopus), the document description, the selection of publications reporting on the review focus, and the identification of research trends and gaps. We used three keywords related to the use of bicycles for the review: "Cycling", "Urban Cycling" and "Bikeability"; we chose "GPS" as a keyword to identify the use of LBS and likely mobile devices; and "Gamification" as a keyword for the use of game elements in non-gaming contexts. Surely a 


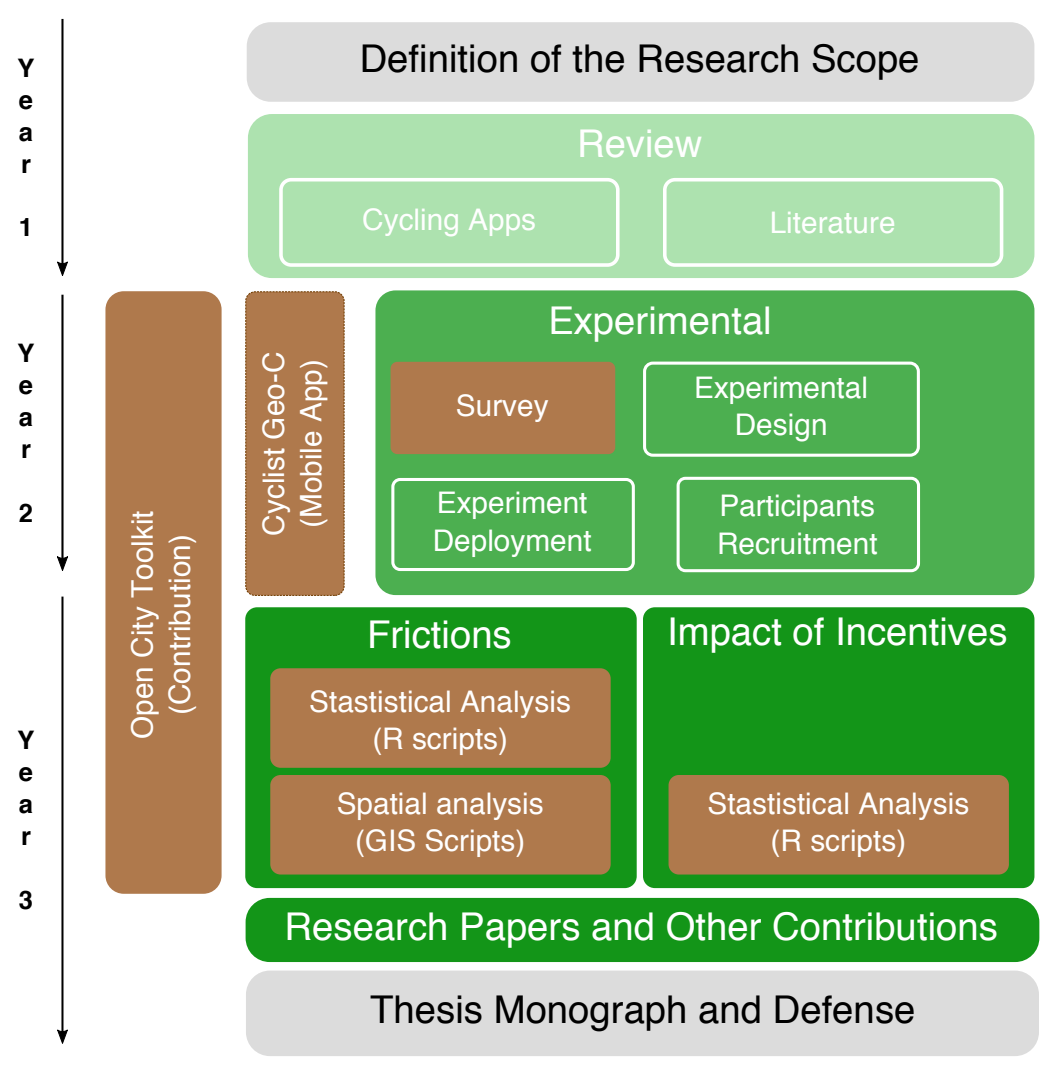

Figure 2.1: Research methodology.

never-ending attempt to test alternative keywords could have been tried. Since we found no major changes in query results after trying alternative terms (e.g., biking, bicycle, cycle, cycleability, serious games, games, GNSS, georeferencing, etc.), we decided that these search terms met our needs.

We linked the keywords using logical connectors, the "OR" operator to link all the cycling related keywords as well as the "AND" operator to link location and game keywords. Figure 2.2 shows not only the links between the concepts and keywords but also the intersection in which the review focused and the logical expression used for the search. The review was limited to publications after 2014 due to the fast obsolescence of mobile technologies which might lead us to obtain either outdated solutions or non-replicable experiments using currently available devices.

Using the search expression at the four repositories we obtained one hundred and forty scientific publications (140). To document the review, we created a simpli- 


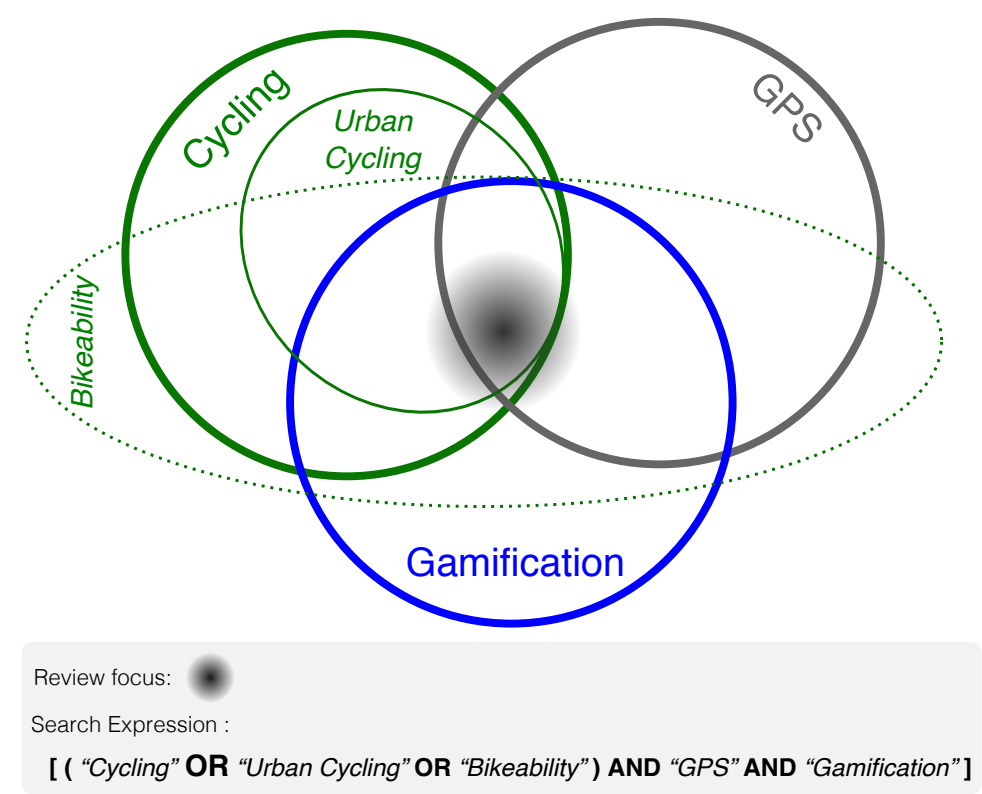

Figure 2.2: Keywords, Search focus, and expression.

fied metadata table which contained publication descriptors such as URL, year of publication, year of publication for the oldest and the latest reference, and the number of citations. Additionally, we grouped some features into dimensions to better describe the publications' contents and provide some quantitative description of the results. References to the reviewed are available on-line as an open repository (Pajarito and Gould, 2017a) (Available at: https://zenodo.org/record/840352) and the four dimensions with the correspondent features are listed in Table 2.1.

After describing the reviewed publications, we selected those reporting on cycling and extended the description with additional features such as: device or devices used for experimenting, location technology adopted, name of the application or platform used, current availability of the application, type of research approach (e.g., quantitative, qualitative, or mixed), country and city of deployment of the experiment. Based on that extended description, we identified the research trends, the associated research topics, and some other particularities regarding dimensions and features. We also compared the results obtained from cycling and non-cycling publications separately to identify the differences. 


\begin{tabular}{ll}
\hline Dimension & \multicolumn{1}{c}{ Features considered } \\
\hline - Literature review, True when compiling or analysing publications \\
- Experiment or test, True when reporting experiments or tests of hardware, \\
software, applications or algorithms \\
- Design, True when reporting new methodologies, platforms, information sys- \\
tems or frameworks \\
- Survey, True when reporting data collection from participants, interviews, \\
werkshops or its analysis \\
- Reported participants, the number of reported survey or experiment parti- \\
cipants when available
\end{tabular}

$\begin{array}{ll}\text { Relationship } & \text { - Urban traffic, True when reporting analysis of traffic conditions } \\ \text { with urban } & \text { - Health, True when reporting health benefits assessment } \\ \text { transport and } & \text { - Gports performance, True when reporting performance measurements } \\ \text { cycling } & \text { vironmentally friendly actions } \\ & \text { - Cycling, when reporting use of bicycles in urban areas }\end{array}$

- Location services, True when reporting the use of GPS or other location technology

- LBS Related, Description of the location technology used "Without Device", "With Device" or "With device and location"

\section{Relationship - Mobile devices, True when reporting the use of mobile devices}

with LBS

- Wearables, True when reporting the use of accessories such as wearables, virtual reality headsets or similar devices

- Social networks, True when reporting interaction via social networks

- Web pages, True when reporting interaction through websites

- Virtual survey systems, True when reporting remote surveys

$\begin{array}{ll}\text { Relationship } & \text { - Intrinsic motivation, True when reporting intrinsic motivation } \\ \text { with gamifica- } & \text { - Extrinsic motivation, True when reporting extrinsic motivation } \\ \text { tion } & \text { Negative impacts of gamification, True when evaluating the impact of gami- } \\ & \text { - Gamification relationship, Description of the use of gamification }\end{array}$

Table 2.1: Structure of the description table. 


\subsection{Experimental design}

Our first experiment aimed to evaluate the impact of incentive types provided by geo-games on urban cyclists. For designing the experiment, we hypothesised that collaboration-based rewards in mobile gamified applications would lead to a higher increase in enjoyment, intention, satisfaction, and engagement with urban cycling than competition-based rewards. Consequently, the experiment followed a between-groups design to measure and compare the impact of virtual rewards provided by geo-games in cyclists of three European cities.

Participants were randomly divided into two balanced groups. They used an application with either an interface featuring collaboration (group A) or competitionbased rewards (group B). The independent variable (i.e., factor controlled during the experiment) was the "type of reward used for motivation" while the dependent variables (i.e., factors measured) were the overall satisfaction of the participants, their intention to use the bicycle, their engagement with cycling during the experiment as well as their enjoyment competing against or collaborating with other participants during the experiment. Table 2.2 summarises the independent and dependent variables considered during the study and Appendix B shows the questionnaires used.

Intention to cycle was measured in pre-post questionnaires following the theory of planned behaviour adapted by Gatersleben and Haddad (2010), asking participants "My intention to use a bicycle is" and a Likert scale (Likert Rensis, 1932) from "Very weak" to "Very strong". Satisfaction was measured via two means. Firstly, in the post-questionnaire asking participants "how satisfied / dissatisfied in general you were with cycling during the experiment" and a Likert scale from "Very dissatisfied" to "Very satisfied". Secondly, by identifying the sentiment related to the tags or words used to describe bicycle trips as positive, neutral or negative as described by Pang and Lee (2008) For example, a participant recording the "inspiring" tag, with positive sentiment polarity, means satisfaction while a participant recording the "dangerous" tag means dissatisfaction.

Engagement with cycling during the experiment was assessed through two complementary means: the number of trips, and the number of tags recorded during the experiment. Likewise, we compared the levels of enjoyment between the two groups by asking in the post-questionnaire "I found collaborating with other cyclists enjoyable", for the collaboration condition, and "I found competing against 


\begin{tabular}{|c|c|c|}
\hline $\begin{array}{l}\text { Independent } \\
\text { variables }\end{array}$ & $\begin{array}{l}\text { Dependent } \\
\text { variables }\end{array}$ & $\begin{array}{c}\text { Measurement of } \\
\text { dependent variables }\end{array}$ \\
\hline & Intention to cycle & $\begin{array}{c}\text { Comparison of answers to } \\
\text { "My intention to use a bicycle is" } \\
\text { using the scale: } \\
\text { ("Very Weak" }(-3) \text { "neutral" (0), "Very Strong" (3)) }\end{array}$ \\
\hline $\begin{array}{l}\text { Type of reward: } \\
\text { a. } \\
\text { Collaboration-based }\end{array}$ & $\begin{array}{l}\text { Satisfaction with } \\
\text { cycling }\end{array}$ & $\begin{array}{l}\text { 1) Answers to question } \\
\text { "Indicate how } \\
\text { satisfied / dissatisfied in } \\
\text { general you were with: } \\
\text { cycling during the experiment" } \\
\text { using the scale: } \\
\text { ("Very dissatisfied" (-3), "Very satisfied" (3)) } \\
\text { 2) Comparison of tags' } \\
\text { sentiment polarity. }\end{array}$ \\
\hline \multirow[t]{2}{*}{$\begin{array}{l}\text { b. } \\
\text { Competition-based }\end{array}$} & $\begin{array}{l}\text { Engagement with } \\
\text { cycling }\end{array}$ & $\begin{array}{l}\text { 1) Number of trips recorded during and after } \\
\text { the experiment. } \\
\text { 2) Number of tags recorded during and after } \\
\text { the experiment. }\end{array}$ \\
\hline & $\begin{array}{l}\text { Enjoyment with } \\
\text { collaboration or } \\
\text { competition }\end{array}$ & $\begin{array}{l}\text { Answers to the question } \\
\text { "I found collaborating with / competing } \\
\text { against other cyclists enjoyable" } \\
\text { using the scale: } \\
\text { ("Strongly disagree" (-3), "Strongly agree" (3)) }\end{array}$ \\
\hline
\end{tabular}

Table 2.2: Independent and dependent variables of the experiment.

other cyclists enjoyable" for the competition condition, and a Likert scale from "Strongly disagree" to "Strongly agree".

To get background information about the participants' overall attitude towards cycling, we used a modified version of Pooley's questionnaire (Pooley et al., 2011), shown in Appendix B. Although we aimed to classify participants' cyclist profile, and Gatersleben and Haddad (2010) as well as Dill and McNeil (2012) offered questionnaires, these did not fit into our design since they were either very long or not applicable to the European context. Figure 2.3 presents the methodological approach of the experiment.

The experiment produced two main datasets used to identify the impact of incentives on urban cycling when using geo-games and, afterward, the frictions inhibiting bicycle commuting. Section 2.3 explains the two datasets in detail, first, the set of answers from the pre-post questionnaires, and second, the trips' tra- 


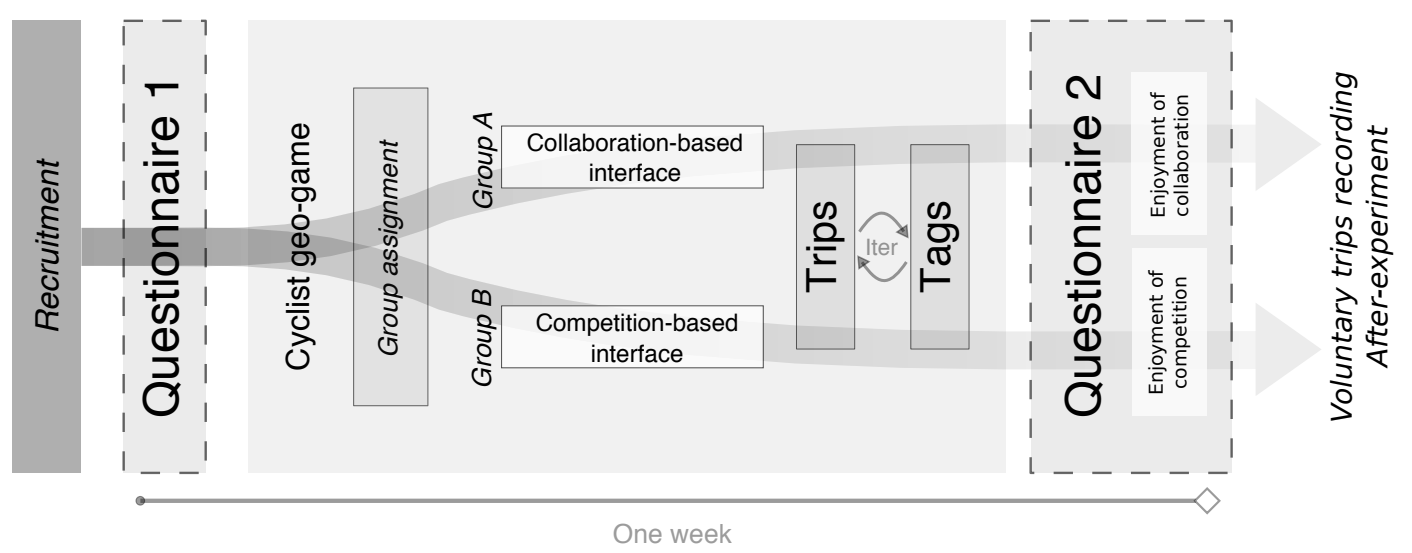

Figure 2.3: Experimental design.

jectories and tags to describe participants' experience. The following subsections describe the activities and instruments used for data collection.

\subsubsection{Study area}

The experiment was deployed in three European cities: Münster in Germany, Castelló in Spain, and Valletta in Malta. The cities were selected mainly due to the contrasting cycling environment provided, also because of the existing relationships with research centres and cycling advocacy groups aiming to collaborate with the research. The city of Münster is located in the North Rhine-Westphalia region, northwest Germany, with 300.000 inhabitants, mostly flat, and with an extended and high-quality network of dedicated bicycle lines; $39 \%$ of the trips in Münster are made by bicycle (Münster Stadt, 2017).

The city of Castello is part of the Valencian Community on the Mediterranean coast of Spain, with 180.000 inhabitants. It is mostly flat, and has a network of bicycle lines that covers the main corridors of the city and connects with the surroundings; about $2 \%$ of the trips in Castello are made by bicycle, and the tendency grew during the last years (Ayuntament de Castelló, 2016).

The city of Valletta and the surrounding the urban area of Malta is a network of small cities within the Mediterranean island with multiple bays and low hills. It has more than 400.000 inhabitants, and almost no cycling infrastructure apart from dedicated bus lines shared with cyclists; less than $1 \%$ of the trips in Malta are by bicycle (Land Transport Authority, 2013). 


\subsubsection{Participants recruitment}

The study recruited 20 participants in each city aiming to have a significant number of participants in the two groups and, at the same time, to ensure an equivalent number of participants despite the different cities' cycling modal share. For the recruitment, we used printed posters, flyers, messages on social media and emails to the local cycling advocacy groups. Participants were required to be Android phone users as well as to meet the researchers to install the application, receive the instructions for the experiment, and provide feedback. Participants had three tasks: i) complete the first questionnaire for demography, cycling profile, mobile technologies, satisfaction and intentions to cycle information; ii) install the geo-game, record each bicycle trip and describe it with up to three tags upon

arrival; iii) complete the second questionnaire at the end of the experiment to provide feedback.

Fifty-seven participants (19 in Münster, 20 in Castelló, and 18 in Malta) joined the experiment during the summer-autumn 2017: in Münster from September 18 to October 6, in Castello from October 16 to November 3, and in the urban area of Malta from November 9 to 30 . Each participant received a nominal $€ 10$ reward after finishing the tasks.

\subsubsection{Pre and post questionnaires}

The first research tool was the set of pre-post questionnaires for gathering information from participants (see Appendix B). The pre-questionnaire had four sections: i) demography, ii) cycling profile, iii) use of mobile applications, iv) satisfaction with cycling. The demography section had questions for gender, age, postal code, marital status, education level, and mode of transport used in the city.

The answers for the following sections used a Likert scale with seven values from -3 to 3 (Likert Rensis, 1932), which allowed participants to express the level of agreement with the provided sentences (as measure, participants saw a dotted line instead of the numeric values of the scale). The cycling profile section had the 15 questions proposed by Pooley et al. (2011) for participants to report the level of agreement with each of them from "Strongly disagree" (Scale value: -3 ) to "Strongly agree" (Scale value: 3). These 15 questions, listed in Table 2.3, aimed to gather participants' perception and attitude towards the use of bicycles in the city. 


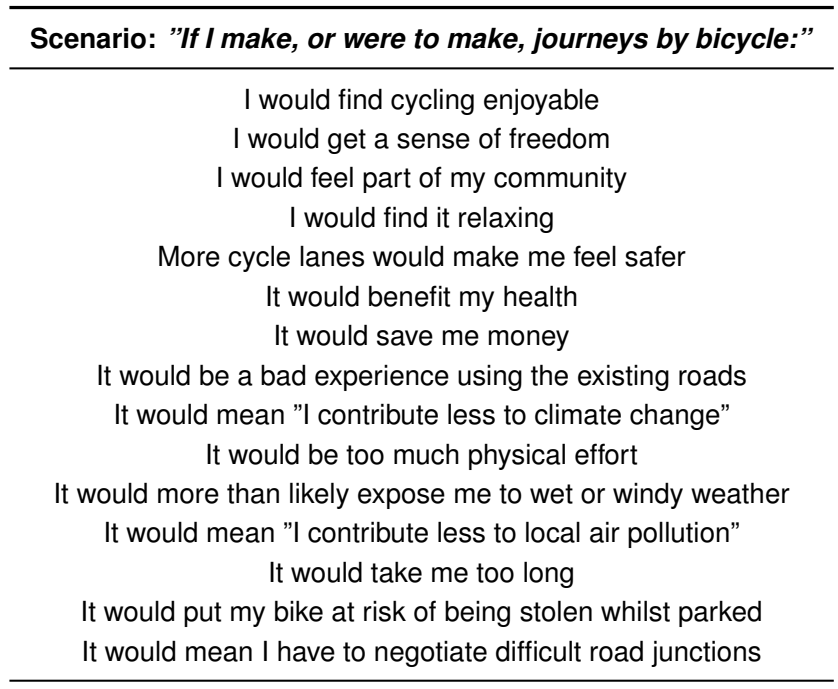

Table 2.3: Questions for the cycling profile.

The section "use of mobile" combined multiple choice questions asking for the mobile applications or games preferred by participants, time and money spent on them. Additionally, it asked for applications and accessories used for tracking cycling or other physical activities. The satisfaction section had the three questions from Gatersleben and Haddad (2010) and also used the Likert scale to report participants' intentions to cycle, play mobile games, and use a cycling application.

The post-questionnaire complemented the dataset through three sections. First, it replicated the questions for satisfaction and engagement with cycling to compare pre-post conditions. Second, it asked for the intentions to cycle, to use cycling applications, and to use the given application after the experiment. Finally, it had questions on the participants' overall experience during the experiment and a space for comments and recommendations.

The participants filled the pre-questionnaires and received the instructions for using the application during the first meeting with researchers. After recording their bicycle trips using the application for one week at least, participants met the researchers for the second time, filled the post-questionnaire and provided feedback. At the second meeting participants commented on their experience and voluntarily decided whether or not to continue recording trips after the experiment. 


\subsubsection{The Cyclist Geo-C geo-game}

The "Cyclist Geo-C" geo-game allowed participants to track their bicycle trips and describe each trip with up to three tags upon arrival. It offers two different interfaces as seen in Figure 2.4: the collaboration-based interface that calculated the proportion of participants' trips and tags with respect to the city's total as a percentage; and the competition-based interface that defined participants' position on the city's leaderboard based on the number of trips and tags recorded.

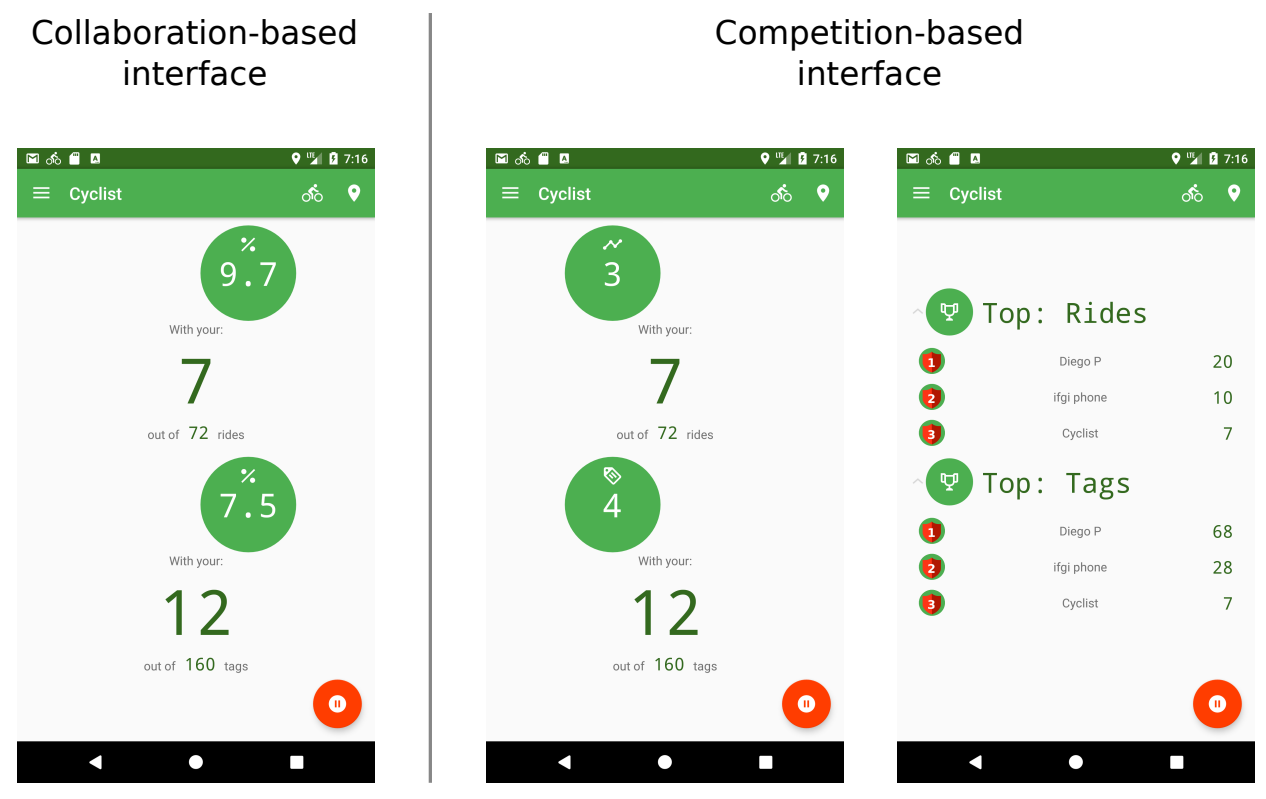

Figure 2.4: Application interface for the two conditions.

Cyclist Geo-C randomly assigned one of the two interfaces to a new participant. It provided different modules to control trips' records, choose up to three tags upon arrival, set up a user profile, check the dashboard, and the leaderboard (visible only for the competition-based interface). The application supported four languages: English, European Spanish, German and Catalan. It had a modular and open architecture (Pajarito et al., 2018) shown in Figure 2.5, and became one of the tools to empower participation and shape future cities, as part of the Open City Toolkit - OCT (see Degbelo et al. (2016a,b)). 


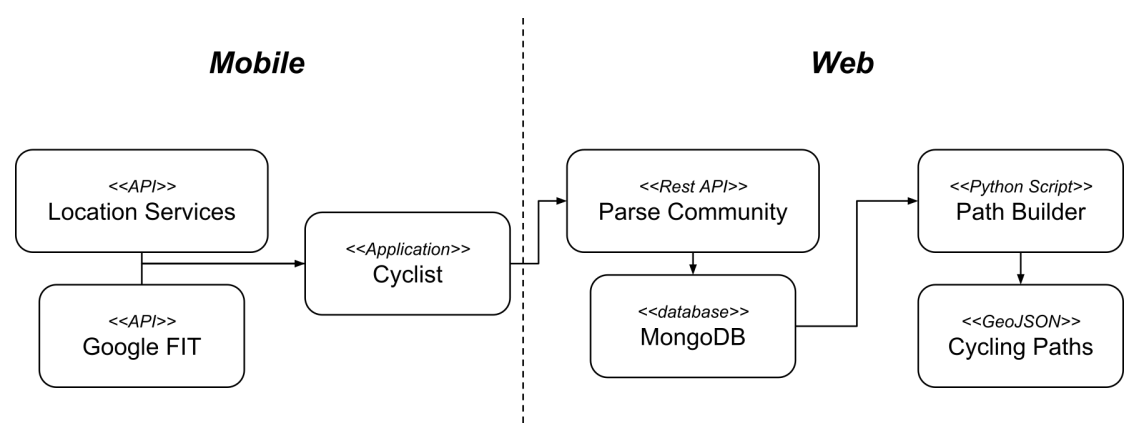

Figure 2.5: Application high-level architecture.

\subsection{Data}

During the research, we used various data sources, most of them coming from the experiment participants and combined with secondary data to describe the cycling environment of the three cities. The first group of data was the compilation of answers from pre and post questionnaires part of the experiment with the Cyclist Geo-C application. The participants filled questionnaires before and after recording their bicycle trips. We anonymised the dataset using a random identifier only for distinguishing the answers. It has data for participants' cycling profile, their overall attitude towards cycling, intentions to cycle, and the use of mobile phones and mobile games.

The second group of data were three different datasets: Location, with the sequence of coordinates and timestamps of each participant; Measurements, with the sequence of distance and speed estimated by Google Fit (Google Inc. 2017) which we discarded due to bad quality and mistiming of the estimation; and Tag, with a set of up to three tags describing each cycling experience. The detailed description of this open dataset (Pajarito and Gould, 2018) is available in Appendix C.

From the raw data, we built the experimental dataset composed of three subsets. First, we created a point dataset called "origin_destination" which contained the point geometries where each trip started and ended with attributes for latitude, longitude, altitude, and precision coordinates. Each point also had the timestamp which indicates the time when the user started or ended the trip.

We also created a line dataset called "trip_segments" which contained the geometries of the straight lines connecting two locations of the participant. Each 
segment started from an initial point " $p_{i}$ " recorded at a time " $t_{i}$ " and ended the next point recorded by the user " $p_{f}$ " at time " $t_{f}$ ". The time difference between " $t_{i}$ " and " $t_{f}$ " was at most five minutes while the length of the segment was at most one kilometre. Each segment also had the participant and trip identifier, and the segment's sequence number within the trip.

For each of the trip segments, we calculated the distance and speed using the recorded coordinates and timestamps from " $p_{i}$ " and " $p_{f}$ " points, see equation (2.1). Then we classified the segments according to the calculated distance as: "walking segment" when the calculated speed was less than $5 \mathrm{~km} / \mathrm{h}$ (Gong et al., 2015); "cycling segment" when the calculated speed was between 5 and $50 \mathrm{~km} / \mathrm{h}$ (Bigazzi, 2017); or "non-cycling segment" when the calculated speed was more than 50 $\mathrm{km} / \mathrm{h}$.

$$
\text { segment speed }=\frac{\operatorname{distance}\left(p_{i}, p_{f}\right)}{\Delta \operatorname{time}\left(p_{i}, p_{f}\right)} .
$$

We created a second line dataset called "trips" which contained the geometries of each of the trip paths. A trip was a line (also called polyline by GIS users) defined by the ordered sequence of trip segments. It started from origin point " $p_{i}$ " of the trip's first segment and ended at the destination point " $p_{f}$ " of the trip's last segment. Each trip also had the participant's identification, trip's identification, the number of segments, start and end times.

In addition to the experimental dataset recorded by participants, our analysis used a secondary dataset to define a comparable framework for the three cities. The secondary dataset consisted of the existing bicycle paths in the cities of Münster and Castelló as well as the planned bicycle paths around Valletta. For the city of Münster, the source of the bicycle paths was the OpenStreetMap (OpenStreetMap Contributors, 2017) (we downloaded the line elements with the tags "bicycle=yes" and "cycleway=yes"). For the city of Castelló, we obtained the bicycle paths from the city transport authority (Ayuntament de Castelló, 2016), and for the city of Valletta, we created a digital version of the national bicycle network plan (Land Transport Authority, 2013).

For the urban boundaries, we used data from OECD functional urban areasFUA (OECD, 2017) and urban morphological zones-UMZ (European Environment Agency, 2006). These last two datasets served to compare the three urban areas of the study and the existing or planned bicycle lanes. The experimental 
and secondary datasets were stored using the open GIS-compatible file format GeoJSON (Butler et al., 2016).

\subsection{Estimating the impact of incentives on urban cycling}

To estimate the impact of incentives on urban cycling we used descriptive statistics and the mean and variance comparison for the answers reported using the Likert scale. Such impact estimation helped us to answer research question number two "How might collaboration and competition-based incentives (presented in mobile applications) impact urban cycling?". The analysis consisted of descriptive statistics and the comparison of mean and variance of the answers to the questionnaire especially for satisfaction, intention to use the bicycle and engagement with cycling. We tested to check the normal distribution of each of our dependent variables described in Table 2.2 using Shapiro and Wilk (1965) test, statistically compared their means and distribution with either $t$-Student (Stein, 1945) or Wilcoxon (Gehan, 1965) tests, and estimated the Cohen size of the effect (Lakens, 2013).

We compared the answers from the two groups to identify the differences between intention, satisfaction, and engagement with cycling during the experiment. We also compared the differences between cities and considered the cycling background of participants to feed the discussion. Additionally, we aimed to link participants' answers and cycling patterns, so we aggregated all trip trajectories into a single GIS-compatible layer and stored it into an open and human-readable GeoJSON file format. Those trajectories included not only trip geometries but also the start and stop times, altitude, precision, and speed.

We compared each recorded trip against an ideal cycling scenario based on an expected cycled distance and speed, as described by Bigazzi (2017). We classified each trip into four categories: i) Valid trips, trips that lasted between 0.5 and 300 minutes and covered more than 30 meters; ii) Valid in time, trips that lasted between 0.5 and 300 minutes but did not have location records; iii) Valid in length, trips that covered more than 30 meters but the app did not record any start and stop time, and iv) Non-Valid trips, for trips that did not fit into the previous categories. 
We also classified the tags recorded by participants using the 24 pre-defined tags in the geo-game and its sentiment polarity, see Table 2.4. The tags intended to provide an option for participants to report their satisfaction during the trip in either a positive, neutral or negative way (Pang and Lee, 2008). The analysis of the impact of incentives on urban cycling is presented in Chapter 3 .

\begin{tabular}{ccc}
\hline Positive Tags & Neutral Tags & Negative Tags \\
\hline Fast & Moderated & Slow-moving \\
Quick & Normal & Time-consuming \\
Speedy & Average & Brake-intensive \\
Inspiring & Relaxed & Dull \\
Light & Worthy & Crowded \\
Efficient & Enough & Disconnected \\
Safe & & Dangerous \\
Secure & & Risky \\
Sheltered & & Hazardous \\
\hline
\end{tabular}

Table 2.4: List of tags in the "Cyclist Geo-C" geo-game.

\subsection{Identifying frictions inhibiting bicycle commut- ing}

To identify the frictions which potentially inhibit bicycle commuting we used the geospatial datasets crowdsourced with the Cyclist Geo-C Application and analysed them using geospatial analysis tools. The identified frictions helped us to answer the research question number one: "Which are the frictions potentially preventing citizens from bicycle commuting? Where and when are they found?". Our analysis relied on a comparable framework which considered the existing or planned bicycle paths and urban boundaries.

We used a hexagonal grid of 30-metre cell side to analyse and summarise the bicycle trips, identify frictions, and support the numerical and geospatial visualisation of the results. The hexagonal grid offered a higher spatial resolution and adapted better to the irregular street configurations than a square grid (Birch et al., 2007). Also, the grid offered advantages compared to similar techniques such as map-matching when it comes to the representation of small elements and the independence from a transport network. For example, our analysis included bicycle trips crossing open or pedestrian spaces which would not be considered by map-matching to the network. We built individual grids per city using the local 
coordinate system to ensure a uniform grid size. Then we merged the individual networks into a single layer. The final layer, as well as the experimental datasets, were processed with the WGS84 reference system to ensure reproducibility with future analysis.

Once we had the unified grid, we calculated a set of variables for each cell, described in Table 2.5. The values at each cell came after selecting the points or lines intersecting each grid cell using the GIS function "st_intersects". The values became attributes of the existing grid layer.

\begin{tabular}{|c|c|}
\hline Variable & Description \\
\hline n_trips & Number of trips crossing by or intersecting a grid cell. \\
\hline n_segments & Number of segments crossing by or intersecting a grid cell. \\
\hline n_cycling_segments & $\begin{array}{l}\text { Number of cycling segments crossing by or intersecting a grid cell used to estimate } \\
\text { the friction intensity. }\end{array}$ \\
\hline n_walking_segments & $\begin{array}{l}\text { Number of walking segments crossing by or intersecting a grid cell used to estimate } \\
\text { the friction intensity. }\end{array}$ \\
\hline n_origin & $\begin{array}{l}\text { Number of trip origin points contained by a grid cell. It defined if the grid cell was } \\
\text { considered or not a friction. }\end{array}$ \\
\hline n_destination & $\begin{array}{l}\text { Number of trip destination points contained by a grid cell. It defined if the grid cell was } \\
\text { considered or not a friction. }\end{array}$ \\
\hline in_umz & $\begin{array}{l}1 \text { when the grid cell is inside the UMZ, } 0 \text { when is outside. It determined whether the } \\
\text { grid cell as in or out the urban area of a city. }\end{array}$ \\
\hline in_fua & $\begin{array}{l}1 \text { when the grid cell is inside the FUA, } 0 \text { when is outside. It determined whether the } \\
\text { grid cell was in or out the study area. }\end{array}$ \\
\hline
\end{tabular}

Table 2.5: Variables calculated during the study.

To define the frictions that inhibit bicycle commuting, we considered the scenario in which a cyclist faced an obstacle or a circumstance that forced her to either slow down, walk the bike or stop cycling. In such a case, the cyclist cannot maintain a constant cycling speed during the trip (Orellana and Wachowicz, 2011). Based on that, we inferred how such scenario would be reflected at an individual grid cell since the application recorded participants' location every 2 to 10 seconds and we calculated the speed of each segment applying equation 2.1. First, we considered a participant was theoretically cycling uniformly at speed between 5 and $50 \mathrm{~km} / \mathrm{h}$ (Bigazzi, 2017) who would likely record from one to three points at a grid cell which corresponds to one, two or three segments, see Figure 2.6 left.

Second, we considered a second participant was theoretically walking at speed lower than $5 \mathrm{~km} / \mathrm{h}$ Gong et al. (2015) or stopped who would likely record much more points at either the same grid cell or the adjacent cells, see Figure 2.6 right. Contrasting the behaviour of the two previous participants, we observed 
that participants cycling would record fewer segments than participants walking or stopped. Similar to the detection of movement suspension patterns described by Orellana (2012), we used the number of cycling and walking segments to identify frictions inhibiting bicycle commuting.

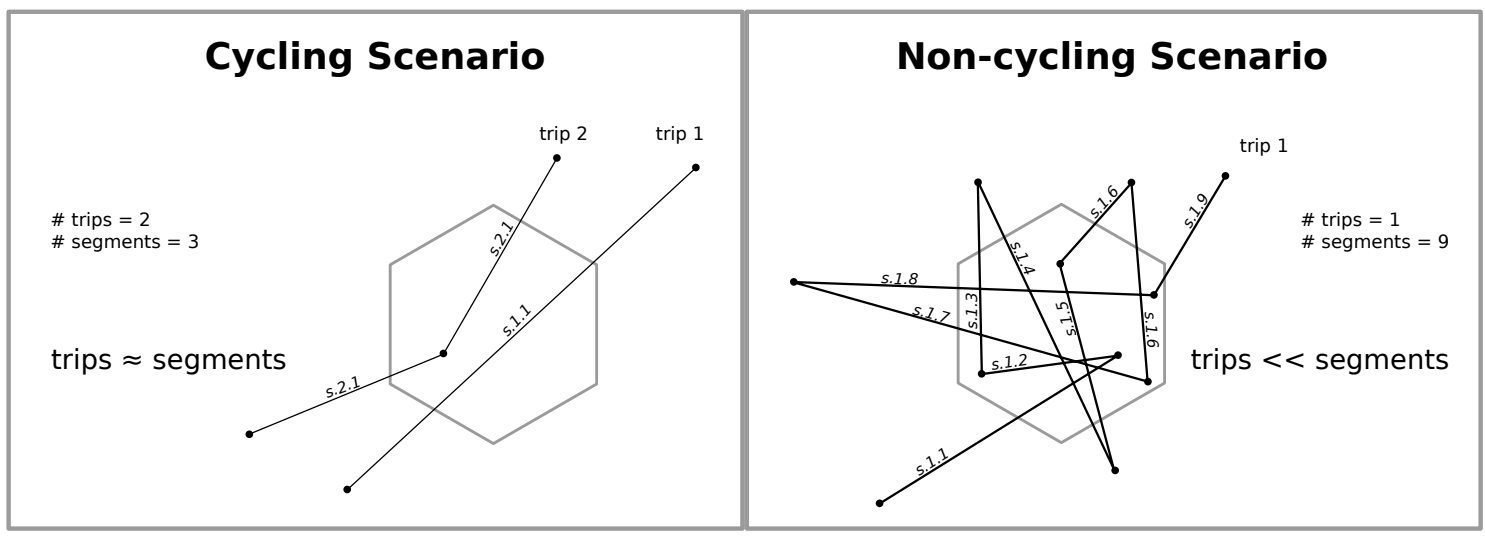

Figure 2.6: Trip and trips segments at a grid cell, two scenarios.

Based on the previous considerations, we defined "Friction intensity" as the proportion of the walking segments recorded at a grid cell compared to the cycling segments recorded at the same grid cell as a percentage, see Equation 2.2 .

$$
\text { friction intensity }=\frac{n \_w a l k i n g \_s e g m e n t s}{n \_c y c l i n g \_s e g m e n t s} \times 100
$$

After calculating the variables and the friction intensity, we proceeded to analyse the trip details. There we checked "when" the participants recorded trips, on which day of the week and at what hour of the day. Also, we analysed "how" participants cycled and calculated the average cycling speed and the cycled distance. Then, we found "where" participants cycled and counted the number of trips in and out of the UMZ. Additionally, we estimated the distance from each segment to the closest bicycle path, assuming that segments recorded at a distance shorter than 30 metres were recorded in a bicycle path. We used distance as a criterion to determine where a participant cycled and, in particular, where they used a bicycle path during the experiment.

We identified the frictions inhibiting bicycle commuting following an iterative procedure to define three levels. As first level frictions, we selected the grid cells intersecting at least one walking segment. As second level frictions, we chose the first level frictions located farther than one hundred metres from a trip origin 
or destination. The areas surrounding trip origins or destinations would probably have more walking segments due to the lower speeds when starting or ending a bicycle trip.

For the third level frictions, we applied two steps. First, we selected the second level frictions in which walking segments were between one half or two times the number of cycling segments. This produced friction intensity values between $50 \%$ and $200 \%$ and would correspond to grid cells where participants not only cycled but also stopped or walked the bicycle. Second, we grouped the adjacent grid cells having a friction intensity between $50 \%$ and $200 \%$ and merged them into a single area to provide insights into the extent of the identified frictions.

We proceeded to explore and visually examine the geospatial representation of bicycle trips, frictions inhibiting bicycle commuting, and the use of the cycling infrastructure. We compared the visualisation outcomes of our approach with similar representations such as the Strava heat map (Strava, 2018a) or the cycling tracks of Wikiloc (Wikiloc Outdoor, 2018) and the raw trip lines. We found the general categories of places in which the identified frictions appeared and the urban elements that potentially produced such friction. Lastly, we visualised the bicycle paths used and not used by participants during the experiment. The analysis of frictions inhibiting bicycle commuting is presented in Chapter 4.

\subsection{Open cities and geo-analysis of urban cycling}

To describe how cycling data and geospatial analysis would enable open cities we discussed the results from participants' preferences on virtual rewards and the frictions inhibiting bicycle commuting. The insights obtained and the discussion itself helped us to answer the research question number three: "How can geospatial analysis on crowdsourced bicycle trip data help us understand urban cycling patterns and improve the cycling environment?". This final discussion led to the compilation of the contribution of this thesis, its limitations and future works presented in Chapter 6 .

The discussion considered three relevant criteria: the impact of adding a cumbersome task of recording commuting trips to a daily routine, the differences in cycling patterns and preferences between participants already using and not using cycling applications, as well as participants' comments and suggestions. Such information was gathered either by the pre-post questionnaires (e.g., questions about the kind 
of cycling application used or the free-text section of the questionnaires) or during the interviews with participants.

We mainly studied the impact of virtual rewards delivered through geo-games and mobile devices to encourage bicycle commuting, the spatial footprint of cycling profiles and the lessons learned from urban cyclists during the experiment. We also examined the benefits of crowdsourcing cycling data collection, analysing frictions inhibiting bicycle commuting, and how data-driven decision making could enable open cities especially when applied to promote urban cycling.

We consider cycling is a social activity that enables interaction within citizens and, therefore, potentially increases citizen participation. Having constant and pertinent feedback through a mobile phone can help to improve not only the knowledge about urban cycling environments but also to better design the urban interventions needed to improve transport sustainability in cities.

We argued the importance of the cyclist and city perspectives for, on the one hand, encouraging cyclists to collect cycling data and, on the other, understanding cycling patterns in cities. In particular, we explore the advantages offered by location-based mobile games which, for example, offer relevant and updated feedback on the preferred commuting routes or the existing cycling communities. We finally examine the advantages of using collaboration-based rewards in gamified tools for cyclists, summarise the lessons learned from participants recording bicycle trips, and describe the distribution of the recorded bicycle trips to shape the contributions of this research.

\subsection{Summary}

This chapter described the research method and the procedures implemented for the thesis. It described how we reviewed the scientific literature reporting on the use of mobile applications and location-based services (LBS) to encourage cycling. It also presented the experimental design, recruiting procedure, tools developed, crowdsourced datasets and its analysis. Afterwards, it explained the evaluation of the impact of incentive types on urban cycling and the identification of frictions inhibiting bicycle commuting. Finally, the chapter presented the considerations during the closing discussion of the thesis. 



\section{Chapter 3}

\section{Mobile technologies for urban cycling}

This chapter describes the existing relationship between mobile geospatial technologies and urban cycling. First, it shows the results of a review of 140 scientific publications which led to identifying four research trends for urban cycling and the existing research gap in the use of mobile gamified applications to promote bicycle commuting. The chapter also presents the potential of using mobile geospatial technologies for analysing urban cycling. Finally, it describes the results of an experiment comparing the impact of collaboration-based and competition-based rewards in enjoyment, intention, satisfaction and engagement with cycling.

Although abundant research about urban cycling, mobile devices, applications or gamification is available, few publications report on integrated approaches of using mobile devices to promote bicycle commuting. Consequently, we used "smart mobility" as the concept driving a literature review and defined it as the use of geospatial technologies to understand and promote sustainable transport through new ways of interaction such as serious games. Our review allowed us to identify the existing research gap and the related work that support our research.

To provide a general idea, we compared the concepts used for defining "smart mobility" to find the relationships among them. We used the relative relevance on the web offered by Google (Google Inc., 2018) as a proxy to the general interest for the concepts during the last years. Figure 3.1 shows a constant and relatively low interest for general concepts like "Cycling", "Biking" or "Urban Cycling" on the one hand, complemented with stationary variations during the northern 
hemisphere summer on the other. The graph also shows a decreasing interest in the "GPS" concept, although there are more and more devices integrating location technologies, this concept showed a decreasing relevance in the latest years possibly produced by the different names given to new mobile location technologies. Finally, the remarkable increasing relevance of the term "Gamification" starting from 2011.
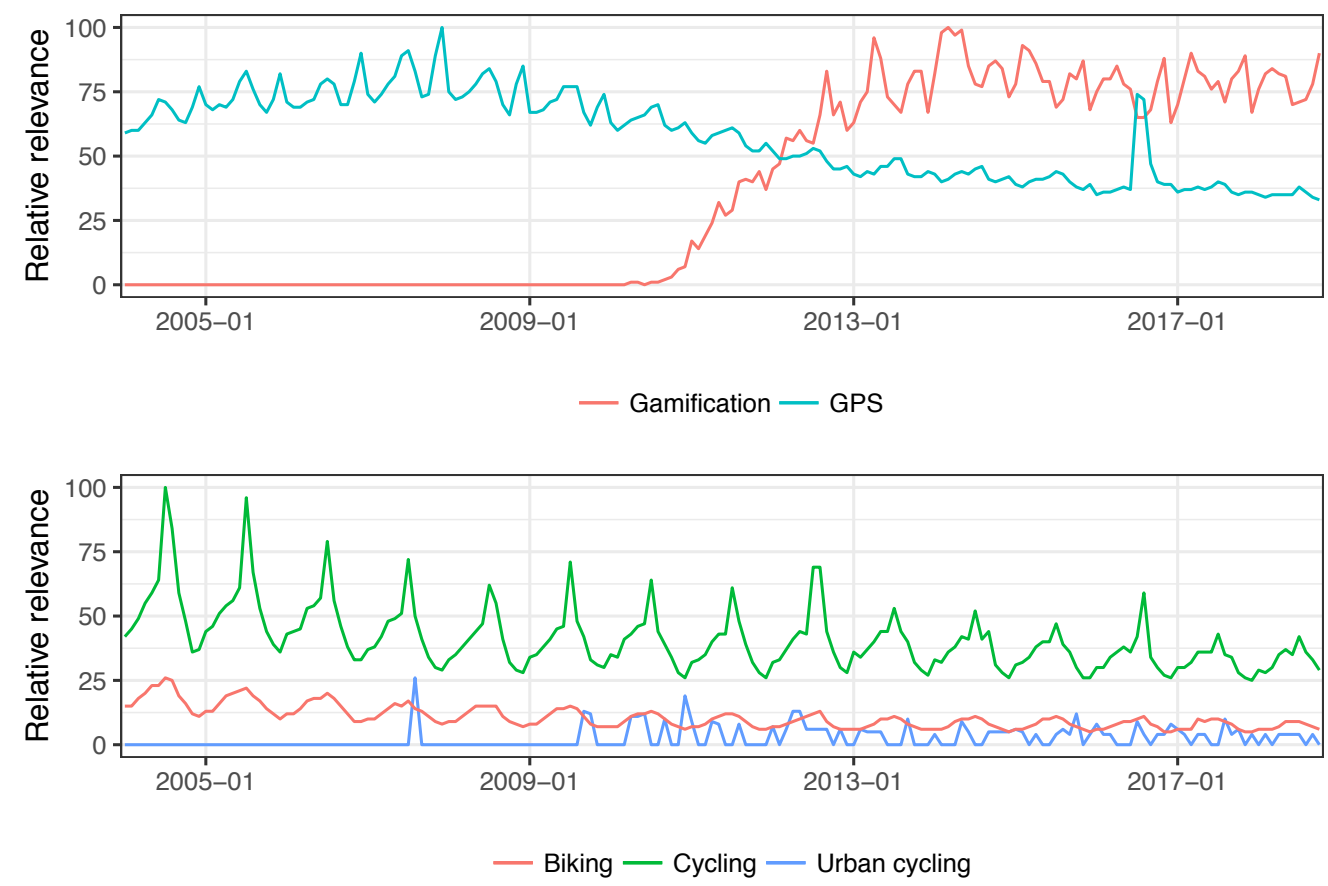

Figure 3.1: Concept interest based on web search.

\subsection{Literature review of cycling related research}

The review was made over one hundred and forty (140) scientific publications, sixty-six (66) from SpringerLink, thirty (30) from ScienceDirect, twenty-four (24) from IEEE Xplore and twenty (20) from Scopus. Figure 3.2 shows not only the high contribution of publications but also the strong proportion of book chapters from SpringerLink; the large number of journal papers from SpringerLink and ScienceDirect as well as a number of conference papers from IEEEXplore, and finally, a balanced distribution of publications from Scopus. There were other seven (7) publications reporting either compilation of abstracts, workshop synthesis or 
lecture notes out of the previous classification.

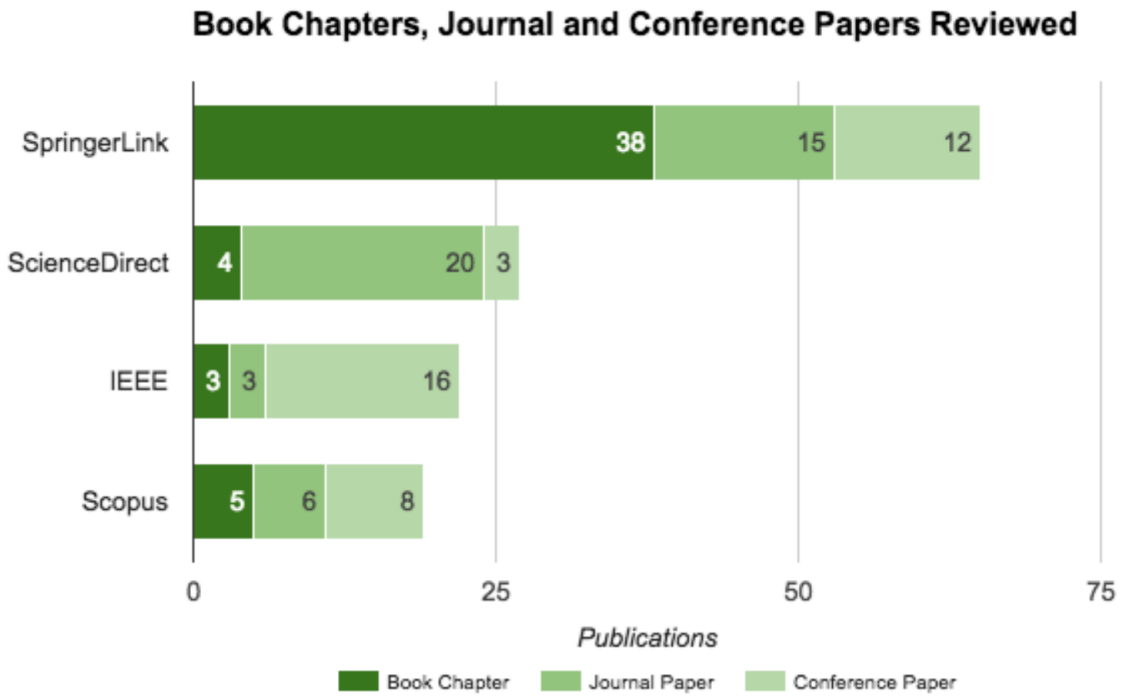

Figure 3.2: Book Chapters, Journal and Conference Papers reviewed.

The number of cycling related publications grew from 2014 to 2016 (see Figure 3.1). Although journal and conference papers grew as well, the number of book chapters decreased in 2016 possibly due to the publication times of journal papers and book chapters. Reviewed publications reported different methodologies, most of them (62, close to $45 \%$ ) literature reviews or experiments and tests (50, close to $35 \%)$, the rest reported either design issues $(20$, close to $35 \%)$ or surveys $(7$, close to $20 \%$ ).

Just thirty (30) publications (close to $20 \%$ ) explicitly reported human subject participants. Their role went beyond experiments or surveys, and they also tested and helped with the design and operation of certain platforms. Some participants contributed to a citizen science platform (MacDonald et al., 2015), sensor calibration (Bleser et al., 2015), and platform functionality tests (Duarte and Carriço, 2016).

While surveys usually reported more than two hundred and fifty (250) participants, there were three publications having 275 (Suh et al., 2015), 394 (Stragier et al., 2016) and 405 (Stieglitz and Hassannia, 2016) participants, but fewer participants for experiments and tests. Just one (1) operative platform reported one thousand (1.000) participants (MacDonald et al., 2015) while eighteen (18) pub- 
Book Chapters, Journal and Conference Papers per Year

60

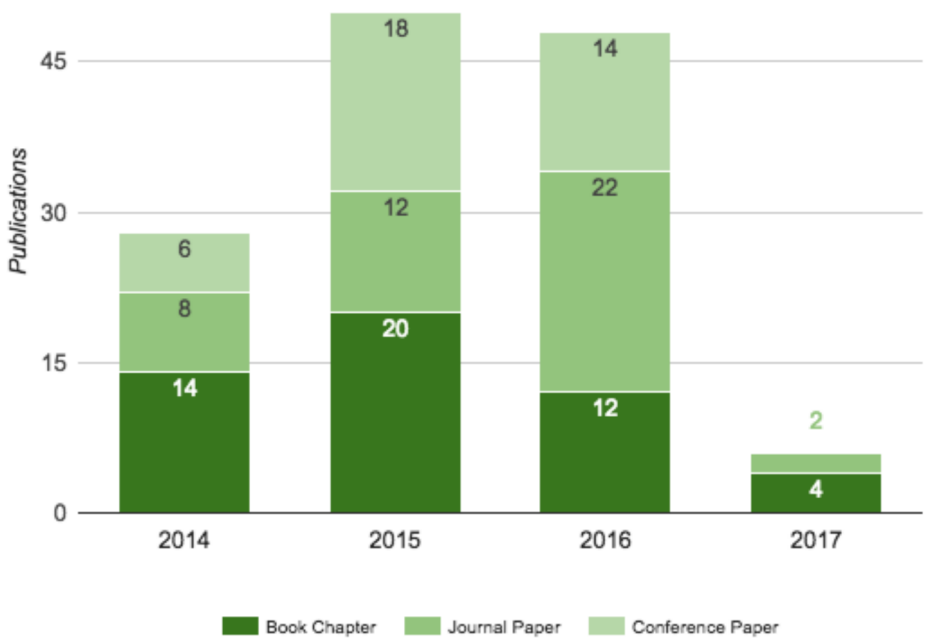

Figure 3.3: Distribution of publications through selected years.

lications reported from ten (10) to fifty (50) participants and evidenced the usual challenges of recruiting volunteers. A remarkable job was done by Boticki et al. (2015) recruiting more than three hundred and five (305) participants in a primary school to use a mobile social learning platform and test virtual badges to reward learning achievements. Also the job of Wunsch et al. (2016) recruiting two hundred and thirty-nine (239) employees for a campaign mixing gamification, motivation, and social dynamics to promote bicycle commuting. These two last publications had the highest number of participants from the review and helped to identify the usual sample size of the reviewed experiments.

Even though "Gamification" was expected to bring most of the publications reporting the use of game elements (see Figure 3.2), just half of the publications (74 of 140 , close to $51 \%$ ) effectively reported it. Some other publications just mentioned "Gamification" as part of their conclusions, recommendations, related or future works. Going deeper into the source of motivation used for the gamified tools, we compared and checked two types of motivation depending on the source, intrinsic when it comes from users, and extrinsic when it comes from external 
elements (Huotari and Hamari, 2012). Among the reviewed publications, they mostly reported intrinsic motivation due to the expected bias coming from the negative implications of extrinsic motivation on long-term engagement described by Matallaoui et al. (2017). Consequently, we found that few documents reported extrinsic motivation as the main strategy ( 5 of 74 , close to $7 \%$ ) while more reported it mixed with intrinsic motivation (32 of 74 , close to $43 \%$ ).

Only a few publications (less than 10\%) reported neither use of a mobile device nor a web tool. It meant that web pages, mobile devices, wearable accessories, augmented reality headsets or biometric sensors are commonly used for experimental purposes, an evidence of the support of information technologies to cycling research. In terms of impact, the review found thirty-three (33) publications with at least one citation (23\%) and a ratio of 1.24 citations per publication, after dividing the number of citations by the number of reviewed publications (174/140). The relevance of this research contrasts the relatively low citation ratio found in the review, especially when considering the multiple publications urging for more research on urban cycling (Handy et al., 2014).

\subsubsection{Research on Urban Cycling}

From the review we selected a subset of 21 publications (15\% approximately) reporting on the use of gamification and mobile devices to promote urban cycling. Although the number of publications was small, the subset provided new insights into having fewer documents reporting "Literature Review", from $45 \%$ to just $10 \%$, and more documents reporting "Experiments and Tests", from 35\% to $70 \%$. These changes show a different state of research with more tools testing than theoretical or literature reviews.

The number of publications related to either sport performance, urban transport, urban traffic, impacts of transportation on the environment, or on public health also changed when contrasted against the cycling sub-set. The documents from the review had a uniform number of publications in each topic (close to 10\%) which concentrated on sport performance (rising to 60\%) and urban transport (rising to $50 \%$ ) for the cycling subset as seen in Figure 3.4. Moreover, almost half of cycling related publications used of location-based services and mobile devices, and the majority used at least mobile devices (about $70 \%$ ).

Just three (3) publications from the cycling subset used freely available applica- 


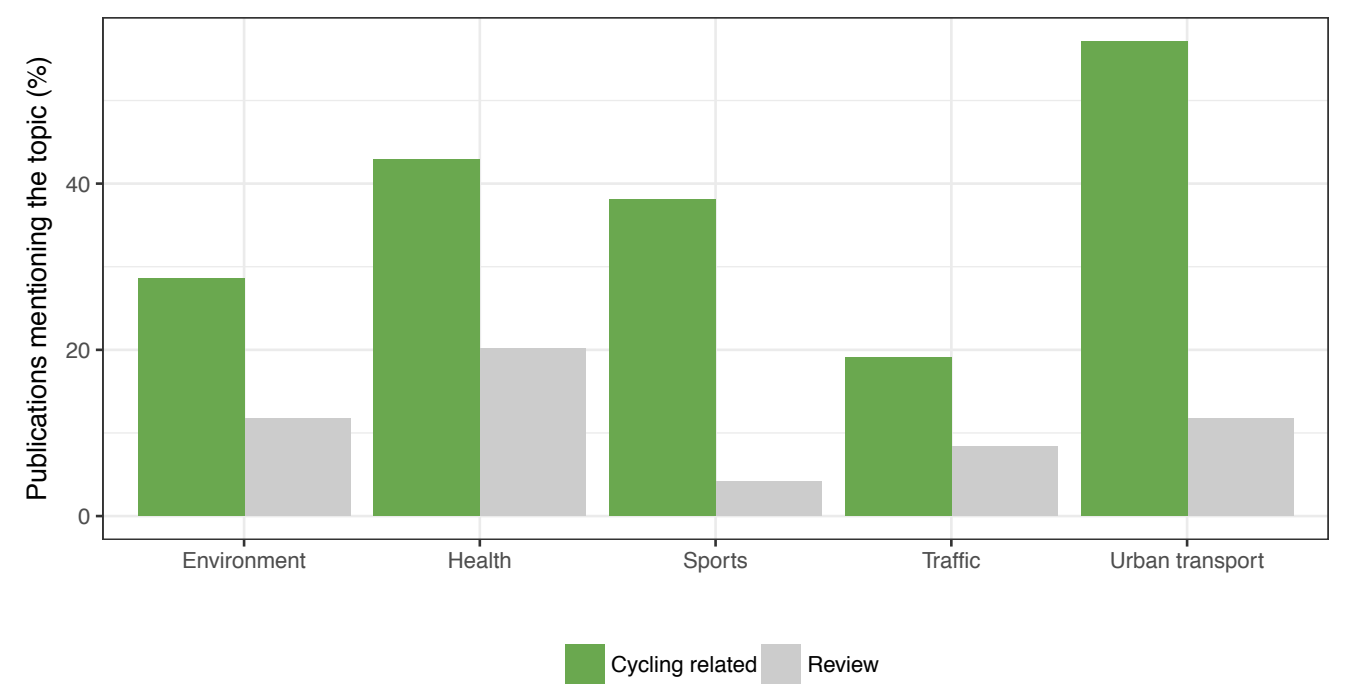

Figure 3.4: Reviewed publications related to cycling.

tions, SmartMo (Berger and Platzer, 2015; easyMOBIZ mobile IT solutions, 2017), Moves (Engineering and Technology, 2016; ProtoGeo Inc, 2017) and SocialCyclist (Navarro et al., 2013; Social Bicycles, 2017). However, Moves is the only one with a considerable number of users, about one million downloads from the Google play store, and the two others had less than one thousand downloads on the same store in February 2017. Mobile applications reported in cycling related publications are mainly prototypes, not published at any store or commercially available.

There was an expected bias towards gamification in the cycling subset and Figure 3.5 shows it with $90 \%$ of cycling related publications reported using gamification. Also, when selecting between the two kinds of motivation mostly used in gamification, $80 \%$ of the cycling subset reported intrinsic motivation (i.e., internal motivators or coming from the individual desires or feelings) and sometimes mixed with extrinsic motivation (i.e., external motivators or coming from rewards or objects). Just a few cycling related publications reported using extrinsic motivation exclusively probably due to the negative consequences in long-term sustainability reported in the literature (Matallaoui et al., 2017).

Although quantitative methods are common in geo-sciences research and 19 cycling related publications reported them (about $90 \%$ ), a remarkable number of publications combined quantitative and qualitative methods (5 of 19 , about $23 \%$ ) or chose qualitative ones (about 10\%). There is a lack of qualitative research in this 


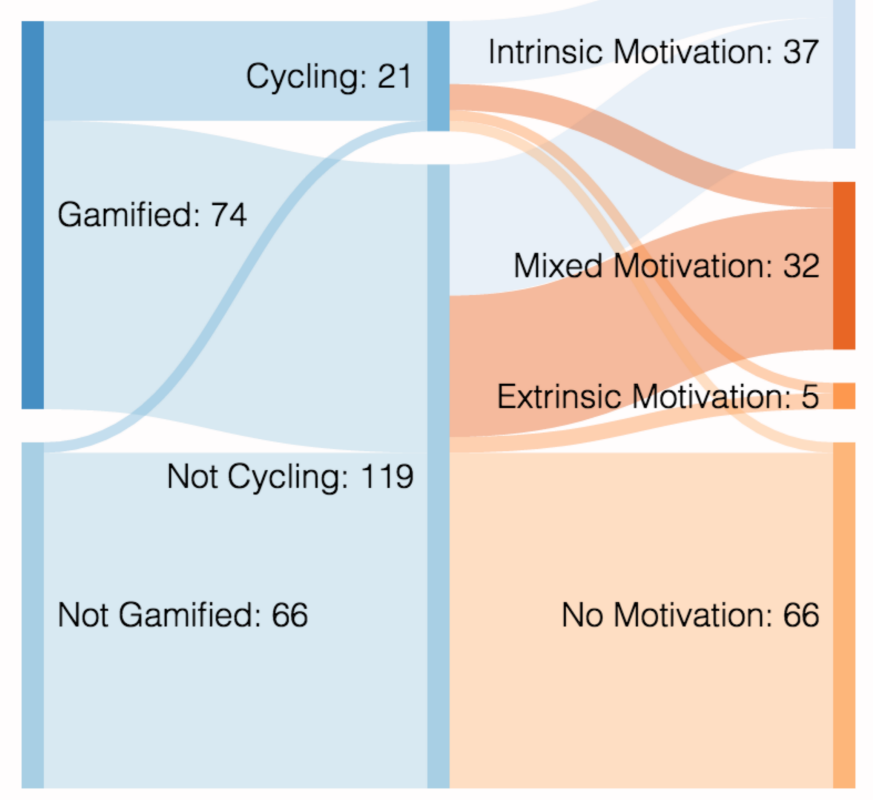

Figure 3.5: Publications reporting on gamification and motivation.

research field. Such an approach could add insights into not only the technological perspective but also the social and human and interaction perspective of cycling patterns.

\subsubsection{The four trends on cycling related research}

After reviewing 21 cycling related publications, we identified four research trends supporting our research. We grouped and described in the following sections.

\section{Gamified platform design}

This section groups the publications reporting tests of gamified tools. We started with the SocialCycle mobile application by Navarro et al. (2013), which was designed to encourage people to either start or increase bicycle riding. The application came after a cycling experience survey and an evaluation of existing mobile applications for cyclists. The design defined a four-axis catalyst approach for encouraging, enabling, engaging and exemplifying cycling aiming to group and define the application functionalities and user interface. 
The physical activity monitoring for aging people - PAMAP application used the concept of "ambient assisted living systems" for motivating balanced training (Bleser et al., 2015) and providinng personalised feedback from sensors and GPS location. Testers found it useful for balancing aerobic and strength workout. The Individual Persuasive Eco-Travel Technology - IPET added a set of gamified tools based on pervasive technologies and supported behavioural change; volunteers seemed willing to adopt sustainable transport alternatives for large scale travels (Meloni and di Teulada, 2015).

A mixed platform using Oculus headsets, and Microsoft Kinect devices provided virtual bicycle rides that increased enjoyment, connectedness and motivation of participants ljaz et al. (2016). The virtual immersion of cyclists into bicycle trips successfully motivated them to workout, bike attached sensors controlled navigation within the virtual environment while the exergame (i.e., a combination of a game and physical excersise) rewarded them based on the trips (El Bastawisy et al., 2016). Considering the term "Fitnessifying", researchers modified popular video games by setting a static bicycle as an augmented gamepad and added physical exercise to increase participants' enjoyment compared to the original game (Leibetseder and Lux, 2016).

The immersive virtual reality (IVR) platform "Rift-a-bike" successfully supported physical exercise and provided a cycling immersive game environment. The platform was effective for gathering physical activity using bicycles came out from the participants' tests (Tuveri et al., 2016). Finally, two wearables devices, a smartwatch and a wrist-worn accelerometer, enabled a gamified mobile application to promote fitness and exercising. Participants expressed satisfaction and enjoyment using it (Zhao et al., 2016).

\section{Experiments with gamified tools}

This section groups experiments that explicitly evaluated gamified tools with users. The first was a "system of apps for smart and collaborative mobility" which used a virtual coin system, interaction through social networks, and a rewarding system for experts' evaluation of challenges. Users positively evaluated not only the platform but also the reliable business model and the sustainable operation (Bellotti et al., 2016).

A methodology for designing new user interfaces considered not only complexity 
of interaction but also exercise intensity. Such methodology was specially tailored after the analysis of existing exergames and allowed users to effectively choose the tools fitting into their exercise times (Dutz et al., 2014). An experiment with students enrolled at the Pittwater Council Approached Macquarie University's program (PACE) reported positive evaluation of two mobile gamified tools. Firstly, a tool to identify environmentally friendly routes for protected areas in North of Sydney. Secondly, a serious game to help on drawing new business ideas by students and experienced business people at the Faculty of Business and Economics (McHugh et al., 2017).

This was a selection of experiments with games for promoting or evaluating cycling conditions. This section exemplifies the research interest in testing new tools to encourage behavioural changes toward environmentally friendly behaviour.

\section{Behavioural change strategies}

This section groups either positive or negative outcomes of publications reporting on gamified strategies. The first publication reported on the use of extrinsic and intrinsic motivation to encourage a modal shift towards environmentally friendly modes of transport. It used an application which encouraged participants to increase walking or cycling. However, after two weeks using the tailored mobile application, participants did not show any statistical significance in the number of walking or cycling trips (Castellanos, 2016). In contrast, the use of financial rewards as gamification strategy for drivers willing to avoid traffic jams and use alternative transport modes during peak-hours produced negative effects. Such effects of extrinsic motivation tended to disappear after removing the financial reward (te Brömmelstroet, 2014).

Qualitative analysis of the negative effects produced by gamification found them not only associated to competition promotion but also able to drive enthusiastic users by obsession rather than enjoyment. Moreover, cycling clubs expressed their concerns about the increasing use of mobile and GPS enabled technologies; they mentioned negative effects (e.g., aggresive behaviour, obsesion for wining) on family and personal relationships of competitive cyclists. In its study, Barratt (2017) compiled a set of common interaction patterns found in the commercial tracking applications (e.g, challenges, quests ,profile development, training and performance, etc.). 
The Biking Tourney strategy promoting alternative commuting within workers of 14 companies in the Greater Boston Area during six weeks was successful. Researchers found $15 \%$ of overall participants starting using the bicycle for commuting and 30\% more occasional bike commuters (Wunsch et al., 2016). The analysis of individual and collaborative challenges encouraging personal mobility changes seemed to work with existing support systems. Beyond the challenges as game elements, individual challenges got better perception from users likely using information technologies or electronic participation to tackle their mobility issues (Schrammel et al., 2015). Finally, the study from Opromolla et al. (2015) found an important role of gamification in policy making and smart city planning. Although its use is not commonly considered by policy makers, the study reports positive effects of including gamified tools in citizen engagement, co-design and participatory decision-making processes .

\section{Data collection}

This section groups initiatives for collecting data using gamified mobile technologies. First, we found a frequent reference to the current lack of urban cycling datasets and the need of highly-detailed travel behaviour data. Then we found a publication reporting on a gamified tool to collect short, long and multimodal trip paths differentiated by transport mode (e.g., Intermodal walking/cycling, car- and ridesharing, electric cars, etc.). After, the tool classified the trip paths according to the level of sustainability of the transport mode used (Berger and Platzer, 2015). The SmartMo application provided information about demand size, citizen needs, attitudes and perceptions towards alternative transport, with measurements of pro-environmental travel behaviour.

The results from the "caring for the environment workshop" compiled the research challenges in dealing with environmental concerns of transportation decisions, the problem of information provided to inform of the consequences of travellers' behaviour, and the role of pro-environmental preferences and attitudes in explaining actual behaviour (Berri and Daziano, 2015). Finally, a theoretical analysis of sampling processes for transport surveys listed the more relevant challenges of GPS-based surveys, including its privacy issues (Armoogum and Dill, 2015). 


\subsubsection{Geospatial technologies for urban cycling}

Based on the results coming out from the review and the four trends described, we identified the existing research gap in the use of mobile gamified technologies to encourage bicycle commuting and better understanding of cycling patterns. Thus we reviewed different applications of mobile geospatial technologies for urban cycling, checked the interaction adopted, and defined the most convenient way to experiment with the incentives fitting best into gamified designs. Such input fed the analysis of the first experiment and helped with the design guidelines for future applications to promote urban cycling.

The geographical space is the primary variable to consider when using geospatial technologies for transport analysis (Miller and Shaw, 2001). Consequently, when analysing cycling as an individual mode of transport that happens at a human spatial scale, we can use mobile technologies to gather detailed cycling data (Norris, 2015; Shin et al., 2015; op den Akker et al., 2014). Tracking cyclists and their cycling activities is, therefore, not only technically possible but also a reliable source of information about mobility patterns (Chen et al., 2018; Yeboah and Alvanides, 2015).

Examples of activities for which data collection helped to support decision making include the identification of travel patterns (Wang et al., 2016), network coverage (Zahabi et al., 2016), infrastructure optimization (Calvey et al., 2015), corridors delimitation (Yeboah and Alvanides, 2015) or routing (Segadilha and Sanches, 2014). Moreover, mobile technologies have also improved traditional data collection methods by integrating location data into questionnaires, or automating surveys and travellers' diaries (Montini et al., 2015).

Researchers have also identified future trends in urban cycling such as potential use of electric bikes in Norway (Fyhri et al., 2017), estimated comfort and satisfaction with cycling infrastructure in the United Kingdom (Calvey et al., 2015), or integrated transmedia to attract, engage and guide new cyclists with music (Albrecht et al., 2016). Additionally, researchers have just added to the research agenda the role of serious games in urban cycling promotion given the wide adoption of gamified tools in cycling applications (Pajarito and Gould, 2017b) (see table 1.1.

Additional to the research status, there is a growing market for tracking sporting activities (Wolff et al., 2017), with popular brands like "Fitbit" offering devices, 
applications and information systems to store sports information (Tomitsch and Haeusler, 2015). Two tech-based companies, Strava and Endomondo, use social and geo-located interaction to engage users with sports (Spillers and Asimakopoulos, 2014; Barratt, 2017).

Among other interests, cities and tech-companies want to understand how people use bicycles and identify the preferred streets and times (Gössling, 2018; Norris, 2015; Claudel et al., 2015). Although the existing tools can provide information about cycling mobility, neither cities nor citizens own or have access to such datasets. In contrast, open alternatives such as the Open Cycle Map rely on citizen engagement and therefore lack the volume of data and popularity of commercial solutions (Yeboah and Alvanides, 2015; Sultan et al., 2017; Reddy et al. 2010). The described scenario validated the capabilities of mobile devices to integrate sensors (i.e., location, accelerometer, pedalling pace, power consumption, etc.), produce data at a human scale, and feed citizen-centered strategies for participation and crowdsourcing (Haklay, 2013; Attard et al., 2016).

There are some new trends that could modify the current scenario. Bicycle rental services or transport-as-a-service initiatives in general show the evolution of cycling mobility; they could also feed new data sources, complement commuting and support business models (Pucher et al., 2010; Gössling, 2018). The majority of these new services and technologies adopt location information as the core business data (Zeile et al., 2016; National Geospatial Advisory Committee, 2015). This could open new and interesting areas of research on the analysis of urban cycling, massive spatial analysis (Handy et al., 2014; Gössling, 2018), or the design of citizen-oriented technology rather than one-size-fits-all solutions (Dill) and McNeil, 2012).

\subsection{The impact of incentives on participants}

This first experiment considers two of the four trends of cycling research identified in section 3.1.2, platform design and experiments with games. We tailored a platform to test motivation coming from collaboration-based rewards and the collection of bicycle trip data. Also, we aimed to frame our research within the two previously mentioned research trends. This section presents not only the experiment deployment, participants profile and trips recorded but also the main results on the impact of virtual rewards on enjoyment, intention, satisfaction and 
engagement with cycling.

The results of the experiment are described in four sections: intentions to cycle, satisfaction, engagement, and enjoyment with competition and collaboration. Although results showed no statistically significant difference in participants' intentions to cycle or participants' satisfaction with cycling after the experiment, they provide insights on the differences between the two conditions. We found higher levels of satisfaction with cycling in the collaboration condition and participants engaged with recording trips and tags after the experiment. Finally, we contrast participants' profile with satisfaction and engagement with cycling, on the one hand, and enjoyment with either collaboration with or competing against other cyclists.

\subsubsection{Participants profile}

Participants of the experiment were aged between 15 and 58 years old (mean 33.4, median 32.5), were mainly singles (23 single and 12 in a relationship but not living together), and included 24 female participants (42\%). Table 3.1 shows additional details of participant profiles.

\begin{tabular}{|c|c|c|c|c|c|}
\hline & & $\begin{array}{l}\text { Münster } \\
\text { (Germany) }\end{array}$ & $\begin{array}{c}\text { Castelló } \\
\text { (Spain) }\end{array}$ & $\begin{array}{l}\text { Valletta } \\
\text { (Malta) }\end{array}$ & Total \\
\hline Male & & 11 & 12 & 11 & 35 \\
\hline Female & & 9 & 8 & 6 & 24 \\
\hline \multirow{4}{*}{ Age } & Min. & 23.0 & 15.0 & 20.0 & 15.0 \\
\hline & Median & 32.0 & 36.5 & 28.0 & 32.5 \\
\hline & Mean & 31.6 & 36.4 & 32.1 & 33.4 \\
\hline & Max. & 38.0 & 46.0 & 58.0 & 58.0 \\
\hline \multirow{4}{*}{$\begin{array}{l}\text { Marital } \\
\text { Status }\end{array}$} & Single & 6 & 9 & 8 & 23 \\
\hline & Not living together & 6 & 3 & 3 & 12 \\
\hline & Living together & 2 & 2 & 2 & 6 \\
\hline & Married & 6 & 6 & 4 & 16 \\
\hline
\end{tabular}

Table 3.1: Demographic information of participants.

Although most participants occasionally commuted by bicycle, in Münster 10 participants reported the bicycle as the only mean of transport. Figure 3.6 shows 
the participants' means of transport and how they usually combined the bicycle with public transport or private cars. Almost all participants (96\%) reported the bicycle as a mode of transport, followed by walking for 28 participants $(49.1 \%)$, the private car for 20 (35.1\%), and public transport for 19 (33.3\%). In total, $17(29.8 \%)$ participants used exclusively bicycle commuting.

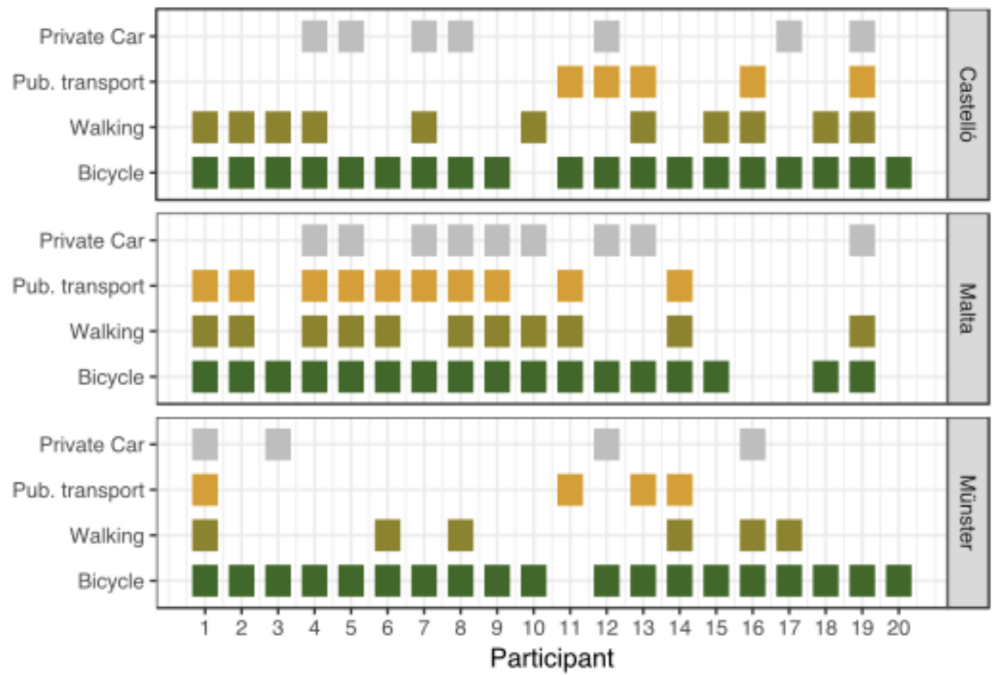

Figure 3.6: Modes of transport used by participants in the city.

Participant cycling profiles were made from the 15 questions in Table 3.1 proposed by Pooley et al. (2011), together with a Likert scale from "Strongly disagree" (scale value: -3) to "Strongly agree" (scale value: 3). These 15 questions allowed us to gather some information about participants' perception and attitude towards the use of bicycles in the city. Participants from Castelló and Valletta provided similar answers: they agreed on their positive perception of cycling, sentiments such as freedom, relaxation or safety during cycling; as well as the benefits in safety, health, and lower pollution that bicycles produce.

Participants from Münster reported quite different answers to some of the questions, in particular, those related to infrastructure and traffic. Specifically, they had the lowest level of agreement with the need to improve cycling infrastructure and the difficulties faced at intersections. (See Questions: "More cycle lanes would make me feel safer", "It would be a bad experience using the existing roads", and "It would mean I have to negotiate difficult road junctions"). Table 3.2 lists profile questions and average answers from participants in each city. 


\begin{tabular}{lccc}
\hline Question & $\begin{array}{c}\text { Münster } \\
\text { (Germany) }\end{array}$ & $\begin{array}{c}\text { Castelló } \\
\text { (Spain) }\end{array}$ & $\begin{array}{c}\text { Valletta } \\
\text { (Malta) }\end{array}$ \\
\hline I would find cycling enjoyable & 2.0 & 1.9 & 1.8 \\
I would get a sense of freedom & 2.6 & 2.8 & 1.6 \\
I would feel part of my community & 1.3 & 1.5 & 0.6 \\
I would find it relaxing & 2.2 & 2.2 & 1.8 \\
More cycle lanes would make me feel safer & 2.4 & 2.5 & 1.5 \\
It would benefit my health & 3.0 & 2.8 & 2.2 \\
I would save me money & 2.5 & 2.8 & 1.9 \\
It would be a bad experience using the existing & 0.4 & 0.8 & -0.9 \\
roads & & & \\
It would mean 'I contribute less to climate change' & 1.7 & 2.1 & 1.2 \\
It would be too much physical effort & -1.1 & -1.8 & -2.0 \\
It would more than likely expose me to wet or & 1.2 & 0.5 & 0.4 \\
windy weather & & & \\
It would mean 'I contribute less to local air pollu- & 2.9 & 2.2 & 1.6 \\
tion' & & & \\
It would take me too long & -1.0 & -2.0 & -1.8 \\
It would put my bike at risk of being stolen whilst & -0.3 & -0.8 & -1.2 \\
parked & & & \\
It would mean I have to negotiate difficult road & 0.0 & 0.9 & -1.4 \\
junctions & & & \\
\hline
\end{tabular}

Table 3.2: Participants' cycling profile.

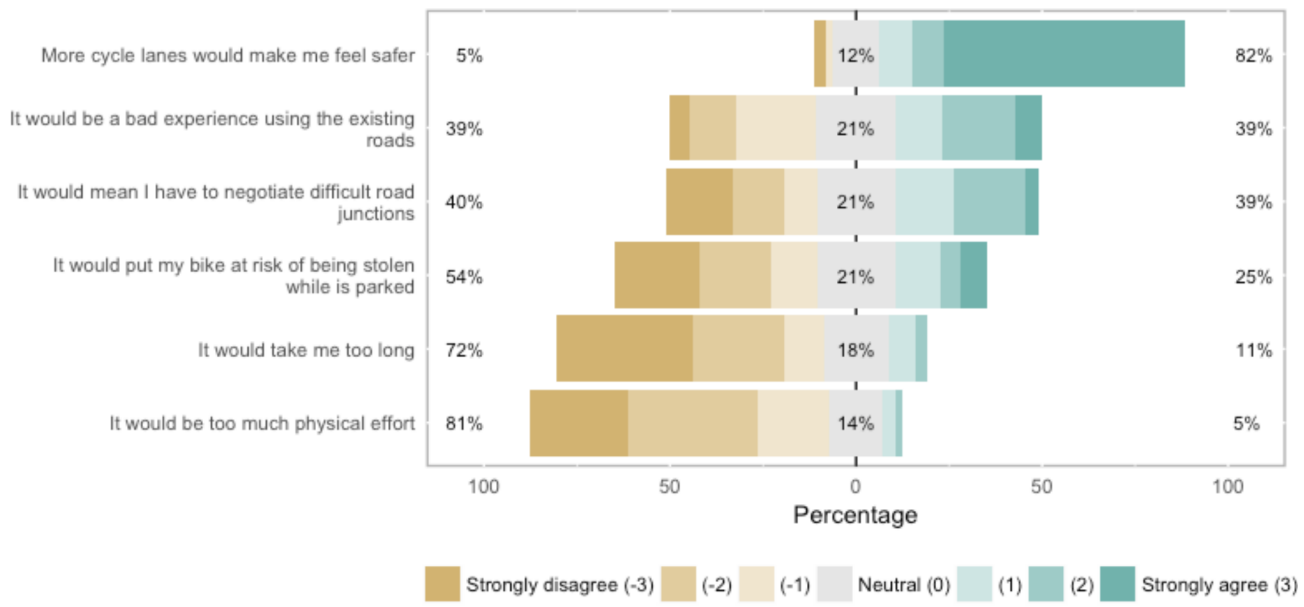

Figure 3.7: Participants perception of cycling in the three cities. 
Since our participants usually commute by bicycle we expected them to consider cycling neither demanding "too much physical effort", taking "too long", nor risky to park their bikes in the city. Figure 3.7 shows participants disagreeing with the previous statements and strongly agreeing with the statement "More cycle lanes would make me feel safer". Due to the cultural differences between cities, we found no clear tendency in scenarios such as the "negotiation with other actors in complex intersections and junctions" or considering cycling a "bad experience with existing roads".

\subsubsection{Participants bicycle trips}

Of the three cities, we found Münster having not only the highest bicycle modal share (Münster Stadt, 2017) but also the shortest average trip duration during the experiment. The average cycled distance was different between the three cities probably due to the different cycling environments, participants' interests, trip purpose and frequency. Since we controlled none of these variables, we only describe the aggregated features of the recorded trip without considering the differences between groups.

On one side, we found shorter trips in Münster (on average $3.1 \mathrm{Km}$ and $34.4 \mathrm{~min}$ ) where a more friendly environment invites to cycle more often and connect also shorter distances within the city. On the other side, we found a more challenging environment in Valletta (on average $5.2 \mathrm{Km}$ and $27.4 \mathrm{~min}$ ) and Castelló (on Average $7.8 \mathrm{Km}$ and $20.9 \mathrm{~min}$ ) where participants might cycle to reach their working/studying places but not for other displacements during the day.

Most of the participants' trips lasted less than 30 minutes (In the collaboration condition about five minutes and the competition condition between ten and twenty), but participants from the collaboration condition usually recorded shorter trips than in the competition condition. We found the trips from the collaboration condition were shorter (less than $3 \mathrm{~km}$ ) than the trips from the competition condition (between 5 and $10 \mathrm{~km}$ ).

\subsubsection{Intention to cycle}

We compared the reported intention to cycle before and after the experiment; first, we did it for all participants and then for the two conditions. Using a Likert 
scale from "Very Weak" (Scale value: -3) to "Very Strong" (Scale value: 3), we found neither statistically significant difference in the intentions before and after nor considerable effect size. We also compared participants' intentions to cycle at each experiment condition (see Table 3.3): before and after the experiment, and then among the two conditions. We did not find any statistically significant difference in either case. The values were before and after very close to the scale values for "Very Strong". In short, the experiment did not lead to changes in participants' intentions to cycle.

\begin{tabular}{|c|c|c|c|c|}
\hline & $\begin{array}{l}\text { Mean } \\
\text { Before }\end{array}$ & $\begin{array}{l}\text { Mean } \\
\text { After }\end{array}$ & $\begin{array}{l}\text { Wilcoxon } \\
\text { Test }\end{array}$ & $\begin{array}{l}\text { Cohen's } \\
\text { Test }\end{array}$ \\
\hline 'My intention to use a bicycle is' & 2.537 & 2.500 & $\begin{array}{l}W=1512.5 \\
\rho=0.8024\end{array}$ & $\begin{array}{l}d=0.035 \\
\operatorname{lnf}=-0.3 \\
\text { Sup }=0.4\end{array}$ \\
\hline $\begin{array}{l}\text { 'My intention to use a bicycle is' Col- } \\
\text { laboration condition }\end{array}$ & 2.577 & 2.423 & $\rho=0.507$ & - \\
\hline $\begin{array}{l}\text { 'My intention to use a bicycle is' } \\
\text { Competition condition }\end{array}$ & 2.500 & 2.571 & $\rho=0.915$ & - \\
\hline
\end{tabular}

Table 3.3: Comparison of intentions to cycle before and after the experiment.

\subsubsection{Satisfaction with cycling}

We compared satisfaction with cycling during the experiment for the two conditions (Q: "Indicate how satisfied / dissatisfied in general you were with: cycling during the experiment" and a Likert scale from "Very dissatisfied", value: -3; to "Very satisfied", value: 3). Participants reported slightly higher (i.e., 8\%) satisfaction with cycling during the experiment in the collaboration condition than in the competition condition (mean collaboration: 2.5, mean competition: 2.296. Wilcoxon Test: $W=343.5, \rho ; 0.306 ; 95 \%$ confidence interval $[-0.29,0.87])$, but the difference was not statistically significant.

We used the tags recorded through the mobile application as a second tool to measure participants' satisfaction with cycling during the experiment. We classified the 791 tags according to their sentiment polarity into: 273 (34.5\%) positive; 284 (35.9\%) neutral; 192 (24.4\%) negative; and 41 (5.2\%) new without any sentiment 
polarity associated. These tags showed $70.4 \%$ of participants describing their trips using tags with either positive or neutral polarity.

Considering that sentiment polarity is related to participants' satisfaction with cycling, we compared the tags recorded in the collaboration and competition condition (see Figure 3.8). As the figure shows, the collaboration condition concentrated the tags mostly in the first ten days of the campaign while the competition concentrated them after day 10. Although participants recorded most of the tags during the first two weeks, 25 per day on average, there were differences between the competition condition, 476 tags $(60.18 \%)$, and the collaboration condition, 315 tags (39.82\%). Besides, there were also differences between cities. While in Malta participants recorded 430 tags (38.6\%) and in Castelló 252 (50\%), participants in Münster recorded 109 tags (11.4\%).

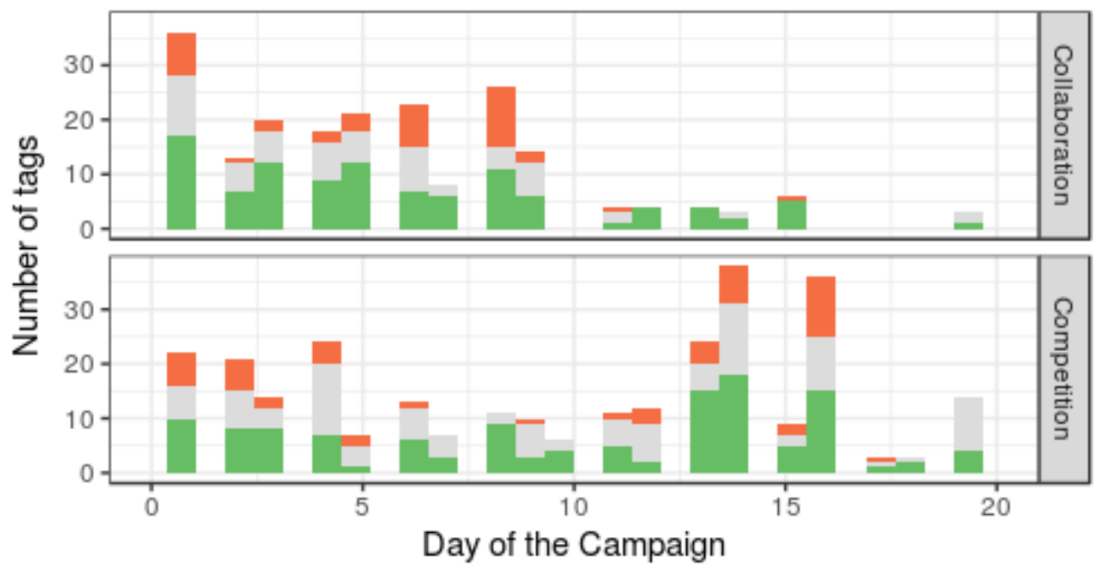

Sentiment Polarity Negative Neutral Positive

Figure 3.8: Tags recorded during the experiment and sentiment polarity.

Studying the detail of tags recorded during the first two weeks, we found 177 positive tags ( 96 collaboration, 81 competition), 128 neutral tags (57 collaboration, 71 competition), and 68 negative tags (38 collaboration, 30 competition). This distribution is another indication of the slightly higher level of satisfaction in the collaboration condition during the experiment. However, Figure 3.8 shows how this trend produced more tags recorded as well as more tags with neutral and positive polarity in the competition condition after the experiment finished.

In addition to tag polarity, we checked tag frequency and meaning. Participants 
mostly referred to the higher speed of bicycles and the city environment (see Table 3.4). We not only found "fast" as the most recorded tag among participants but also "quick", "speedy", "efficient" and "moving"; all together are in the top ten and referring to cycling speed. Additionally, among the 20 most reported tags, we found tags such as "relaxed", "secure", "inspiring", "crowded", "risky" and "safe"; referring to the city cycling environment.

\begin{tabular}{ccc|ccc}
\hline Position & Tag & Frequency & Position & Tag & Frequency \\
\hline 1 & fast & 88 & 11 & worthy & 21 \\
2 & moderated & 65 & 12 & average & 20 \\
3 & normal & 42 & 13 & enough & 19 \\
4 & quick & 33 & 14 & inspiring & 17 \\
5 & speedy & 30 & 15 & light & 16 \\
6 & efficient & 28 & 16 & brake & 15 \\
7 & relaxed & 23 & 17 & crowded & 15 \\
8 & moving & 22 & 18 & intensive & 15 \\
9 & secure & 22 & 19 & risky & 14 \\
10 & slow & 22 & 20 & safe & 9 \\
\hline
\end{tabular}

Table 3.4: Top 20 Tags and Frequency.

\subsubsection{Engagement with cycling during the experiment}

To measure participants' engagement with cycling, we used the number of trips recorded during the experiment. The participants recorded 793 trips not only during the time of the experiment but also after it finished. Although participants had the instruction to record trips during one week, 21 participants recorded 172 trips after the experiment. From these 21, 18 participants (11 from Castellón, 4 from Malta, and 3 from Münster) even recorded trips after the third week. Consequently, we analysed the trips in two scenarios: the trips recorded during the experiment to equally compare participants from the three cities (457); and all recorded trips (793) which include the extreme participants. On average, participants recorded 9.3 trips during the experiment, 15 trips in total. The average increased with the trips recorded after the experiment in Castelló and Malta since in Münster participants recorded fewer trips (see Figure 3.9). Overall, these figures are an indicator of engagement of the participants during the experiment. 


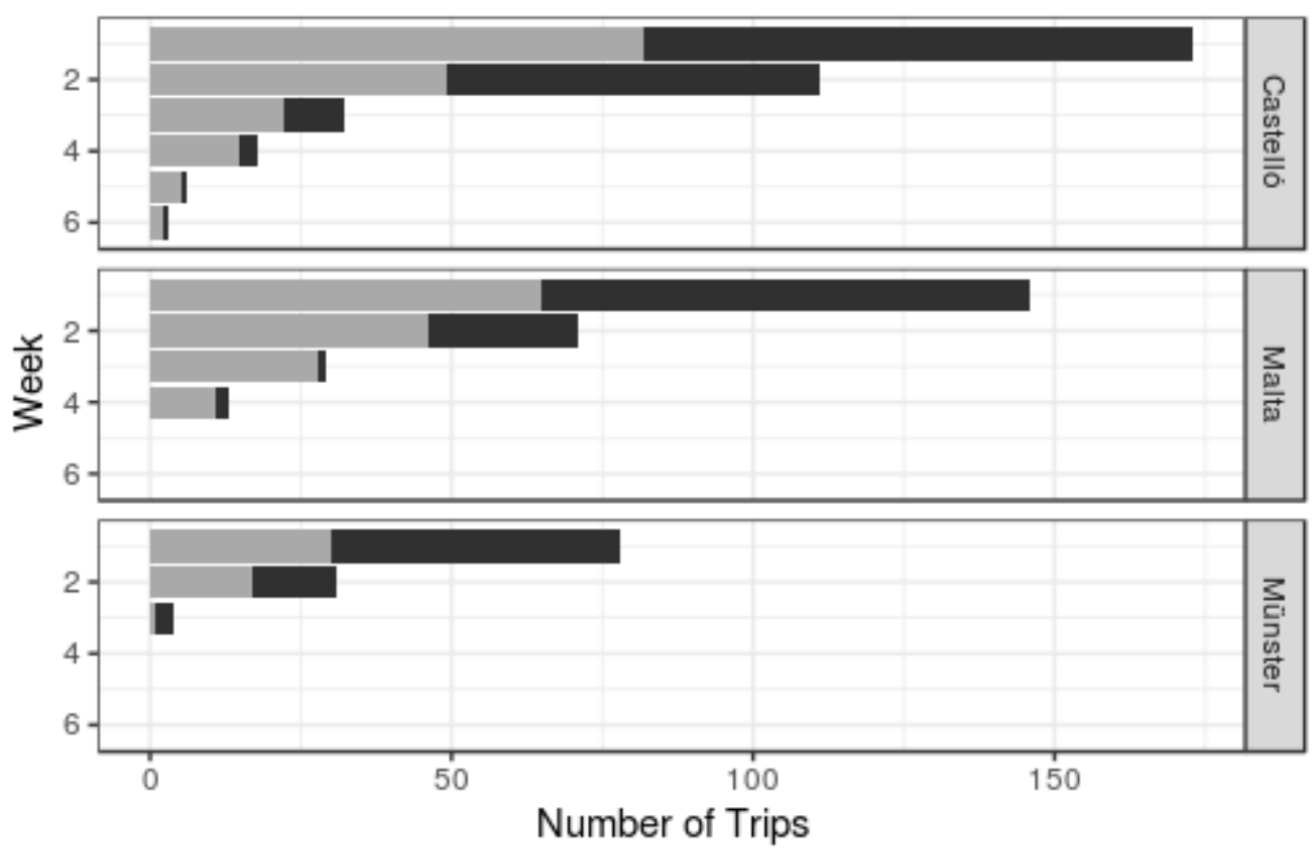

Condition

Collaboration Competition

Figure 3.9: Measure of engagement by city and group.

There were differences between the two experimental conditions regarding the number of trips recorded. During the first two weeks of the experiment, participants from the collaboration condition (321 trips) recorded slightly more trips than participants from the competition condition (298 trips). However, when considering the total number of trips recorded, participants from the competition condition kept recording trips for up to six weeks and, therefore, recorded a higher number of trips.

According to the classification proposed for data analysis, there were 347 trips (43.8\%) valid, 204 trips (25.7\%) valid in time, 34 trips (4.3\%) valid in distance, and 208 trips (26.3\%) invalid. Trips were classified in such a way after deleting records from participants who experienced crashing of the application or recorded an incorrect number of trips at the three cities (4 participants in Münster, 6 in Castelló, and 2 in Malta). 


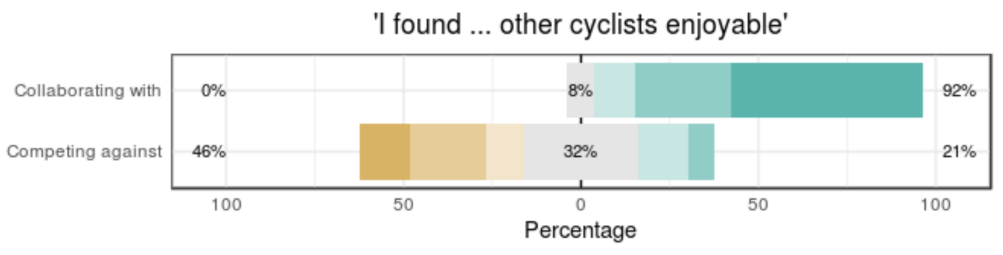

\begin{tabular}{|l|l|l|l|l|l|}
\hline Strongly disagree (-3) & $(-2)$ & $(-1)$ & Neutral (0) & (1) & (2) \\
\hline
\end{tabular}

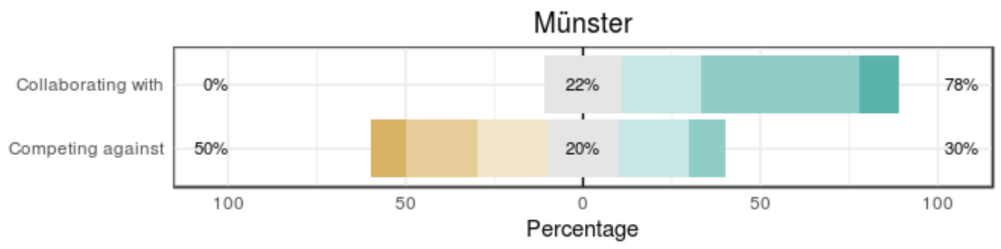

\begin{tabular}{l|l|l|l|l|}
\hline Strongly disagree (-3) & $(-2)$ & (-1) & Neutral (0) & (1)
\end{tabular}

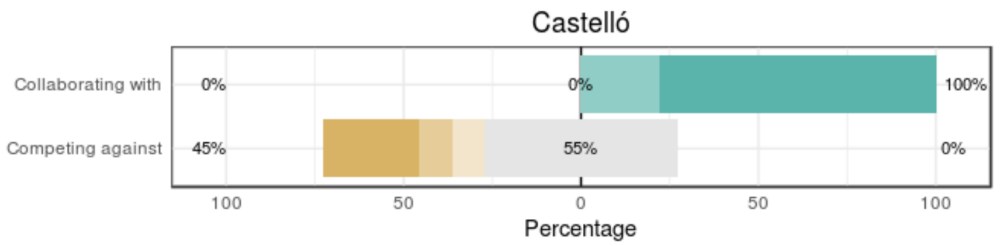

\begin{tabular}{|l|l|l|l|l|}
\hline Strongly disagree (-3) & $(-2)$ & $(-1)$ & Neutral (0) & (1)
\end{tabular}

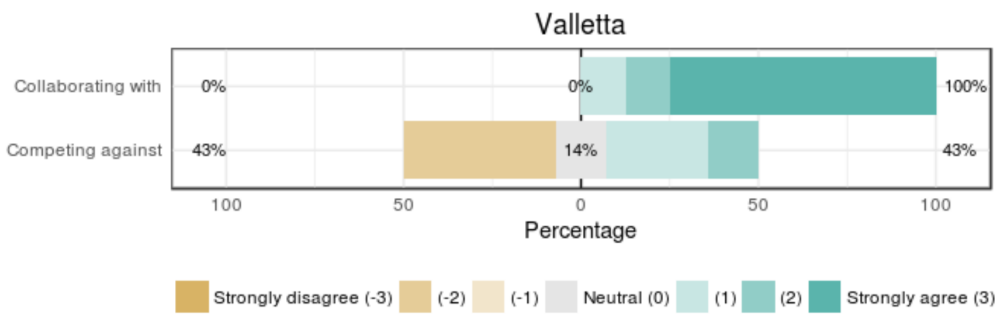

Figure 3.10: Enjoyment with the motivation driving rewards.

\subsubsection{Enjoyment with collaboration and competition}

When comparing participants' enjoyment between the two experimental conditions (Question Collaboration Condition: "I found collaborating with other cyclists enjoyable". Question Competition Condition: "I found competing against other cyclists enjoyable"), participants from the collaboration condition reported a significantly higher enjoyment than participants from the competition condition (mean collaboration: 2.269 , mean competition: -0.679 . Wilcoxon Test: $\mathrm{W}=688, \rho$ i 0.001). Results from the three cities follow the same pattern as seen in Figure 3.10. This result speaks in favour of collaboration as one parameter for customised 
persuasive urban cycling applications. This challenges app providers to rethink their strategies as it suggests that there are cases where competition would not be the best option to make the cycling experience most enjoyable.

\subsection{Summary}

In this section we described the results of a review of 140 scientific publications and the four trends for urban cycling research identified. We went through the latest scientific reports about the use of mobile geospatial technologies in urban cycling and encountered serious limitations of existing commercial solutions to support our research. Based on those findings, we highlighted the existing research gap in the use of mobile gamified applications to promote bicycle commuting.

We presented the results of our first experiment deployed in the European cities of Münster in Germany, Castelló in Spain, and Valletta in Malta. We also described participants' perception of cycling based on the answers to the 15 questions proposed by Pooley et al. (2011). We finally showed the impacts of competition and collaboration-based rewards in participants enjoyment, intention to cycle, satisfaction and engagement with cycling. The chapter concludes with the higher impact of collaboration-based rewards in participants enjoyment as well as in the number of trips recorded in collaboration condition. 


\section{Chapter 4}

\section{Identifying frictions inhibiting bicycle commuting}

This section describes our approach to identify frictions inhibiting bicycle commuting in three cities and aims to address our research question number 1 "Which are the frictions potentially preventing citizens from bicycle commuting? Where and when are they found?". It compiles the results of the experiment deployed at three European cities and the grid-based geospatial analysis. We also present an alternative to analyse urban cycling using crowdsourced cycling data from mobile phones and extend the relatively small offer of mobile applications focused on urban cyclists. Finally, we analyse the frictions identified during the experiment as well as the way such frictions could influence urban cycling, especially about the use of bicycle paths.

Our research aimed to identify, map and analyse the frictions which potentially inhibit bicycle commuting and the places where they can be found. Our goal for this section was to programmatically identify and classify these frictions and, by doing so, support data-driven policy-making in favour of urban cycling. Identifying frictions inhibiting bicycle commuting could help in the prioritisation of new or improved cycling infrastructure (i.e. create, expand or relocate bicycle paths), the definition of traffic-calming areas, or the integration of public transport and bicycles. This section continues by reviewing related work on geospatial analysis for urban cycling, a description of the crowdsourced datasets and the frictions identified. Next, we describe the places with frictions inhibiting bicycle commuting, the cycling patterns observed and the role of bicycle pats in facilitating commuting. 


\subsection{Cities and Urban cycling information}

The analysis of cycling conditions is usually found in transport engineering or transport planning studies (Oldenziel et al., 2015; Koglin and Rye, 2014). Transport analysis typically refers to optimising either the movement of people and goods or the resources impacted by such a task, for example, urban space, fuel, air quality, noise, among others (Rodrigue et al., 2013). City transport plans provided the primary diagnosis of cycling conditions at the three cities of the study and are the components of national and regional cycling statistics (Jacobsen, 2003; Küster and Blondel, 2013). An example of how city transport plans feed broader studies is the analysis of "100 years of urban cycling-policy, use, and practice in 14 European cities in 9 countries" (Oldenziel et al., 2015) which summarised the role of bicycles, their relevance before the 1950s automobile revolution, and its rebirth during the last two decades. Multiple cycling studies have used the cities of Copenhagen (Nielsen et al., 2013) or Amsterdam Pucher and Buehler (2008) as a reference.

In general, transport planning has marginalised urban cycling, and authors such as Koglin and Rye (2014) have highlighted the poor development of the theoretical basis for cycling planning in comparison with planning for motorised traffic. The cycling studies usually either compare people and places with a cross-sectional approach, or measure the conditions before and after urban interventions Handy et al. (2014). The results of such studies are usually too general and not sitespecific; for example, they refer to the convenience of protected cycling facilities especially for women, children, seniors, and also for risk-averse cyclists on roads with motor vehicles (Pucher and Buehler, 2017). Additionally, the studies and scientific reviews commonly refer to the need for more detailed cycling data (Koglin and Rye, 2014).

Sustainable transport such as cycling promises to benefit cities and urban areas and provide alternatives to traditional transport modes due to fewer requirements for adoption and lower maintenance costs (Cohen-Blankshtain and Rotem-Mindali, 2016; Pucher and Buehler, 2008). To comprehend mobility based on physical activity or active mobility researchers have synthesised indexes for the restrictions faced by pedestrians, lately called "walkability" indexes (Leslie et al., 2007). More recently researchers expanded that idea to cycling by considering infrastructure, interaction with motorised vehicles, and cultural adoption across cities (Roughton 
et al., 2012; Pooley et al., 2011).

Safety, a broad category expressed as the potential for collision with motorised vehicles, risk of injury, perceived danger, risk, among other terms, is the common restriction or barrier inhibiting cycling presented across the literature. In addition to safety, researchers referred to other elements impeding access, causing discomfort or delays during cycling. For example, Fishman et al. (2012) highlighted weather and topography while Flügel et al. (2015) identified the number of stops or turns-off during a trip and the pavement quality. The constant trade-off between effort and benefits of cycling also helped to define frictions, especially when having disconnected cycling infrastructure (Fyhri et al., 2017), road crossings or intersections (Hopkins and Mandic, 2017). However, the spatial location of such barriers within the city is not present or is coarsely analysed in cycling research.

Cycling research has also benefited from the relationship with walking, its popularity and convenience for increasing physical activity (Bleser et al., 2015; op den Akker et al., 2014) as well as from the extensive analysis of its medical implications (op den Akker et al., 2014). For our research, we used existing measurements for walking speed, "ranged from $4.58 \mathrm{~km} / \mathrm{h}(127.2 \mathrm{~cm} / \mathrm{s})$ for women in their seventies to $5.26 \mathrm{~km} / \mathrm{h}(146.2 \mathrm{~cm} / \mathrm{s})$ for men in their forties" (Gong et al. 2015), and cycling speed ranged between 12 and 20 km/hour (Bigazzi, 2017) which strongly depends on the urban-conditions.

There are multiple alternatives to promote urban cycling in cities, going from traditional means of communication to technology-based strategies using mobile or web applications. Despite the lack of research dealing with the use of mobile applications to promote urban cycling (Pajarito and Gould, 2017b), other related studies have dealt with technology-based engagement. Several experiences with gamification, a well-known practice of using game elements to enhance a service with affordances for gameful experiences in non-gaming contexts (Deterding et al., 2011; Huotari and Hamari, 2012), and the related products -location-based games or geo-games- have used technology to encourage behavioural change including promote physical activity (Rissel, 2015; Schlieder et al., 2006; Coombes and Jones, 2016; Ahlqvist and Schlieder, 2018.

There is a growing market of cycling applications for mobile phones which adopted gamification techniques to encourage increased physical activity as well as to crowdsource cycling data collection. Such an approach seemed more effective at attracting new users willing to generate cycling data than other web-based tools 
like OpenCycleMap, the cycling version of OpenStreetMap (OpenStreetMap Contributors, 2017; Haklay and Weber, 2008). Some of these applications emphasise social interaction and cycling performance, such as Strava (Strava, 2018b) or Endomondo (Under Armour, 2018), while others directly focus on crowdsourced data collection such as Wikiloc (Wikiloc Outdoor, 2018). Location-based services are a key component of current cycling applications which allowed researchers to explore visualisation and analysis of cycling data mostly with the tools used for analysing motorised transportation (Claudel et al., 2015; Meier, 2015; Adrienko and Adrienko, 2011).

For the geospatial analysis of bicycle trips, many researchers used mapmatching, a popular technique which aggregates and simplifies trajectories using a spatial object as a reference to collapse and link trip lines to the closest street axis (Marchal et al., 1935). Three types of map-matching procedures have been defined: generic, topological and statistical. There are various examples of mapmatching applied to the analysis of cycling such as the work of Snizek et al. (2013) aggregating bicycle trip sketches from 890 participants with the location of positive and negative experiences, the simplification of bicycle trip trajectories recorded by GPS (Sultan et al., 2017; Berger and Platzer, 2015), or the definition of cycling boundaries from bicycle trips (Tang et al., 2016). Other studies have sought to extend the idea of map matching using grids to not only integrate additional variables but specifically to provide higher spatial resolution for phenomena happening at spots within the streets (Larsen et al., 2013) or in open areas outside of the street network.

The interest in geospatial features of bicycle trips is not exclusive to researchers. Citizens often are interested in discovering preferred cycling routes. Some mobile applications offer cycling activity heat-maps (Sainio et al., 2015) as the de facto visualisation. The Strava Global Heatmap (Strava, 2018a) and the Polar global Activity Map (Polar Electro, 2018) are popular examples of the of heat-map visualization. Nevertheless, creation of novel interactive maps are not usually the core of cycling applications; instead they usually adopt mainstream services such as Mapbox, Google or Apple Maps (Nelson et al., 2015; Snizek et al., 2013; Haklay and Weber, 2008).

Unfortunately, cycling application developers and cities are not linked. Very little cycling and transport information is offered for policy makers and transport analysts (Dameri and Benevolo, 2017; Burke et al., 2006; Zeile et al., 2016; Pucher 
et al., 2010). The considerable potential for cycling data-driven policy-making fed by human sensors and mobile phone information (Halko and Kientz, 2010; Barratt, 2017; Wojan and Hamrick, 2015) is hampered by the lack of precise information.

\subsection{Frictions inhibiting bicycle commuting}

The recorded trips came mainly from urban commuters due to the fact that the the recorded location was mostly inside the urban area, during working days/hours, and at low cycling speed. The participants from Münster and Valletta recorded the majority of segments within the urban area $(89.17 \%$ and $93.94 \%)$, whereas participants from Castelló cycled differently on weekdays or weekends. On-weekdays, more than one half of the cycling distance was recorded inside the urban area $(65.09 \%)$, while, on weekends, participants cycled mostly out of the urban area (59.64\% out of the urban area). We noticed different behaviour in participants from Castello due to a combination of more sports cycling in the countryside than in the other two cities and a different spatial configuration of Castello's UMZ. Although the UMZs came from the same source, Castello's UMZ had more dispersed and separated urban areas than Münster and Valletta which had an aggregated UMZ enclosing the small surrounding towns.

Overall, participants cycled more during weekdays and working hours. Figure 4.1 shows the cycled distance during the experiment per day of the week and hour of the day as well as the location in or out of the UMZ. Moreover, participants cycling had a bi-modal distribution of the cycling distance on workdays (St-Louis et al., 2014) and a slightly higher concentration of trips outside the UMZ on weekends.

Participants' average cycling speed was close to $15 \mathrm{Km} / \mathrm{h}$, typical for urban cycling and matched to our theoretical and methodological considerations. We found participants from Valletta with the lowest cycling speed among the three cities, $14.6 \mathrm{Km} / \mathrm{h}$ on average, while Castelló and Münster had a higher cycling speed, $15.0 \mathrm{Km} / \mathrm{h}$ and $14.8 \mathrm{Km} / \mathrm{h}$. The hourly distribution of cycling segments presented in Figure 4.2 shows the trips usually starting after 6:00 in the morning, some early trips in Münster and a participant from Valletta who recorded noncycling segments all night long. Participants from Castelló recorded more trips between 16:00 and 18:00 hours while participants from Münster and Valletta recorded trips earlier in the morning or later in the afternoon. Apart from the 


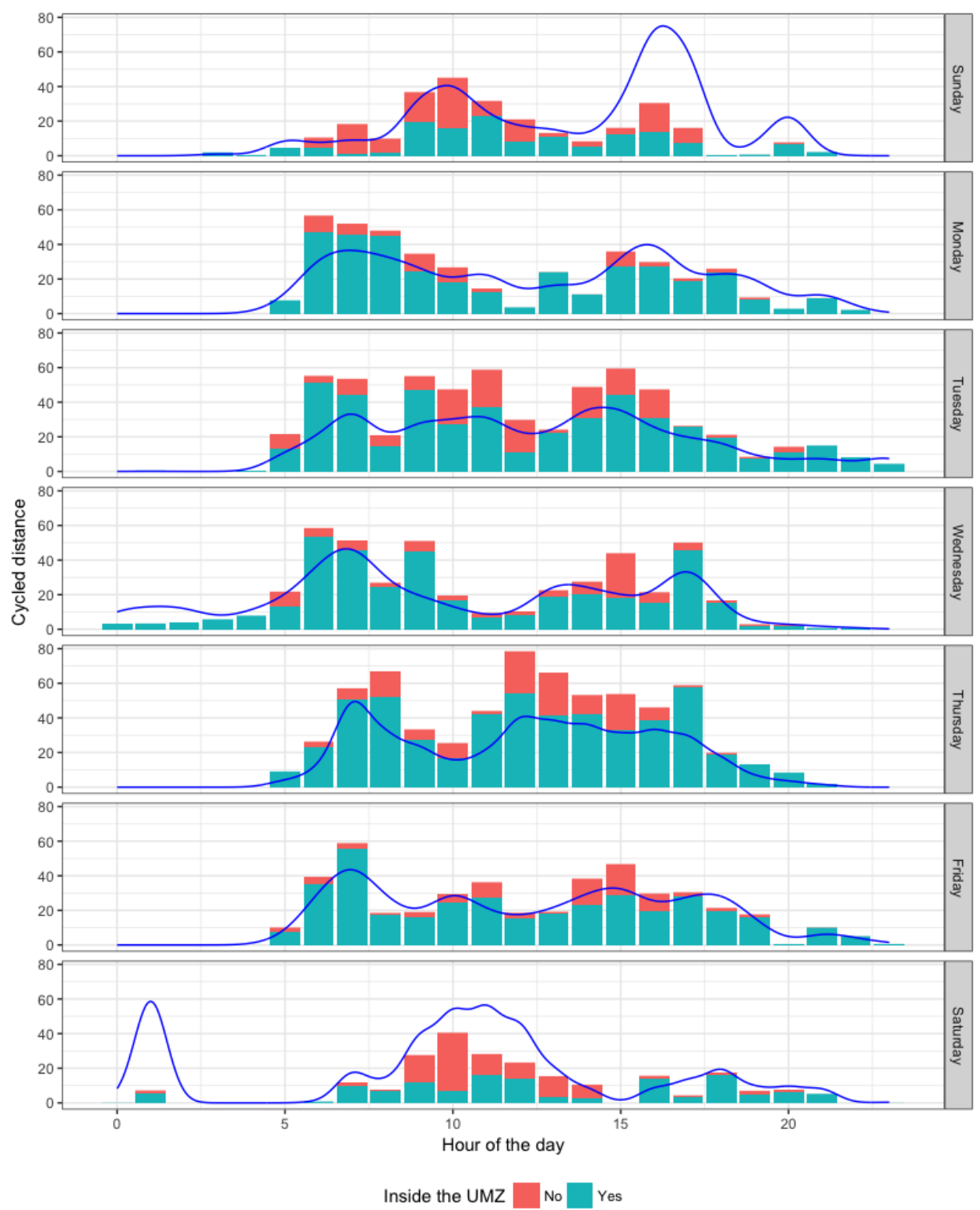

Figure 4.1: Hourly distribution of cycled distance per day of the week.

differences between the local commuting times, we saw a periodic concentration of trips during the day in Münster which could mean a more structured cycling scheduling.

From our methodological approach in Section 2.5, we aimed to locate the areas where participants cycled or walked. The grid cells crossed by participants usually had between one and fifty trips with nearly one hundred segments which 


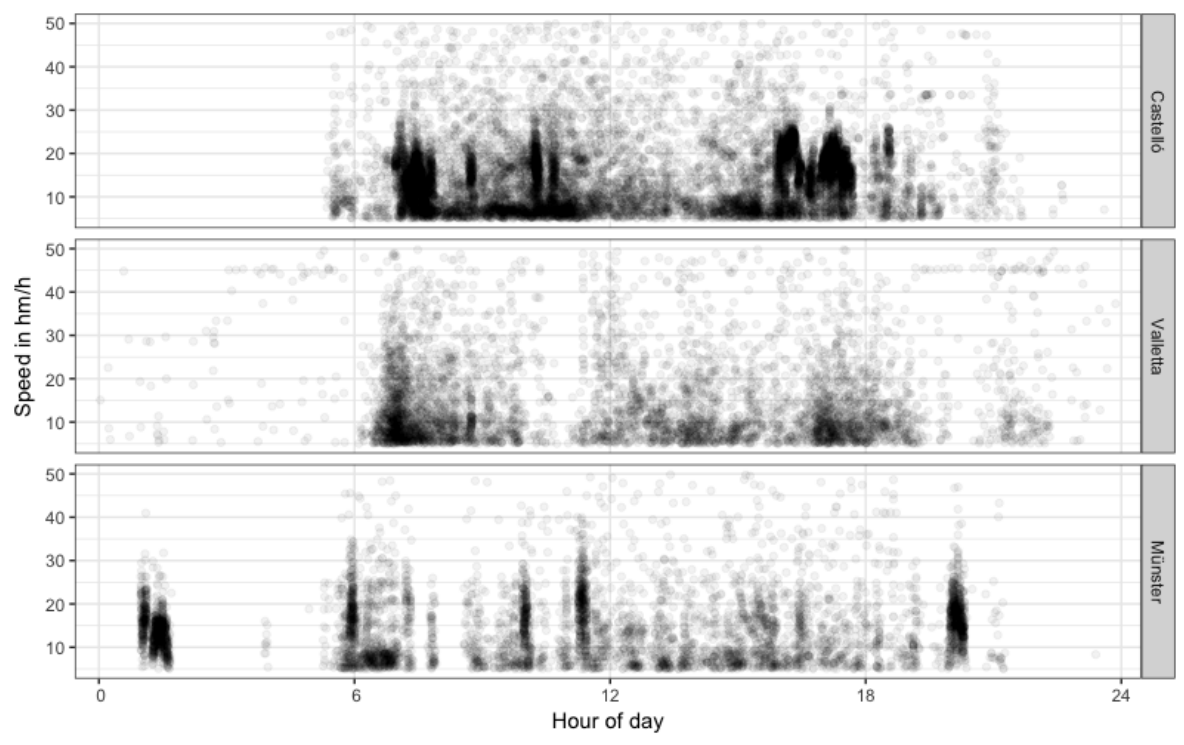

Figure 4.2: Cycling segments and speed distribution during the day.

meant about two or three segments per trip. When considering trips' origins and destinations, the grid cells with at least an origin or destination point usually had up to ten segments. Therefore, we found our participants recording more segments while starting or finishing a trip.

Beforehand, we knew that when a participant stayed at the same location or moved slowly, the GPS sensor kept recording multiple locations and therefore adding trip segments (Orellana and Wachowicz, 2011). Based on that fact, we defined the first level frictions. Figure 4.3 shows some grid cells recorded during the experiment with more than ten segments per trip, especially if they had either origin or destination points. The second level frictions, therefore, excluded the grid cells with either origin or destination points, seen as red crosses along the $x$-axis in Figure 4.3. There were more grid cells with ten segments per trips in Valletta than in Castelló or Munster.

To capture information about frictions' extension and intensity, we aggregated the adjacent grid cells with similar friction intensity to define the third level frictions. We found almost half of the third level frictions in Valletta, 143 frictions, and the rest equally distributed in Münster and Castelló, 71 and 70 frictions. We compared the frictions' intensity and size to visualise the distribution of more significant areas and the most intense cycling inhibition. Figure 4.4 shows four quadrants defined by the size of the grid areas and friction intensity, and the top two quadrants called our 

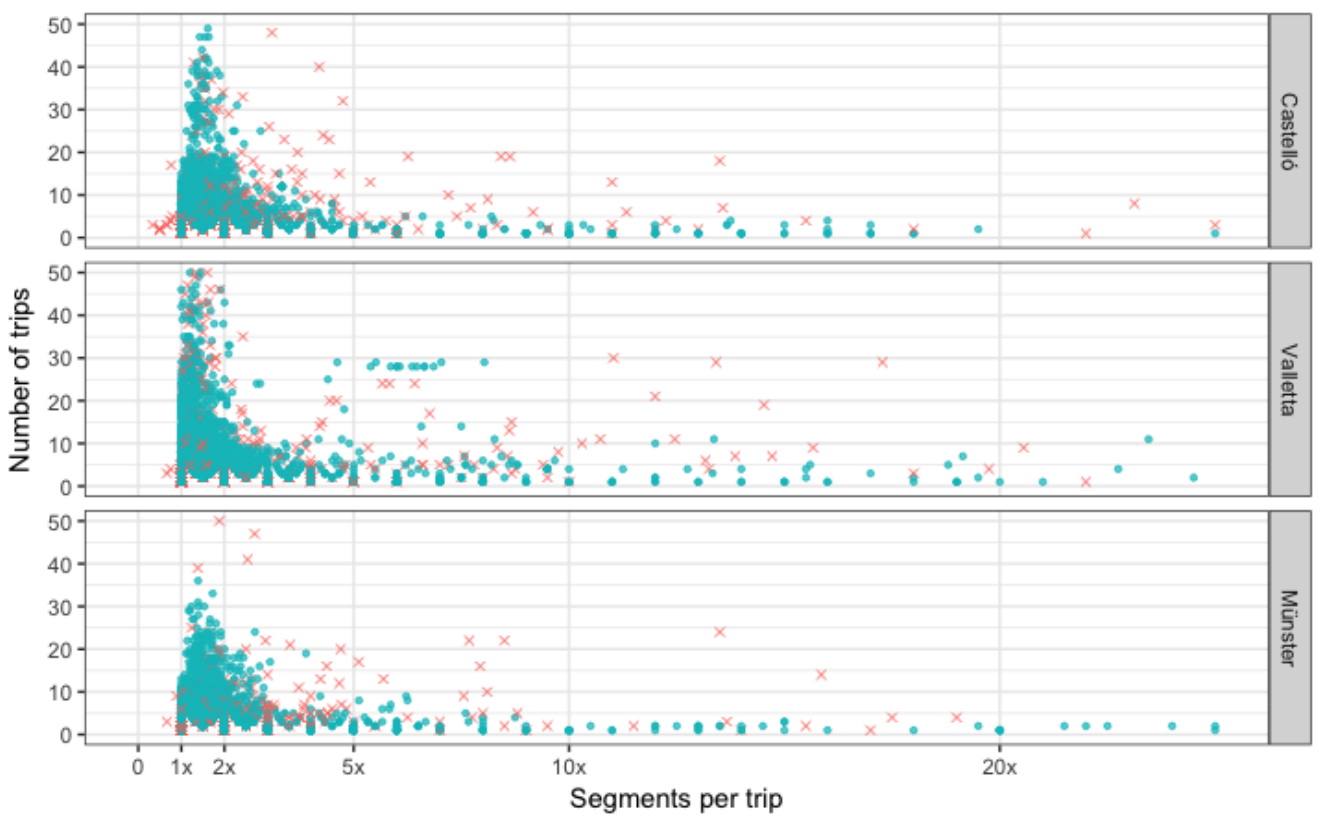

Has Origin or Destination - Without Origin / Destination

Figure 4.3: Trips and segments per trip in the three cities.

attention due to the higher friction intensity produced by more walking segments.

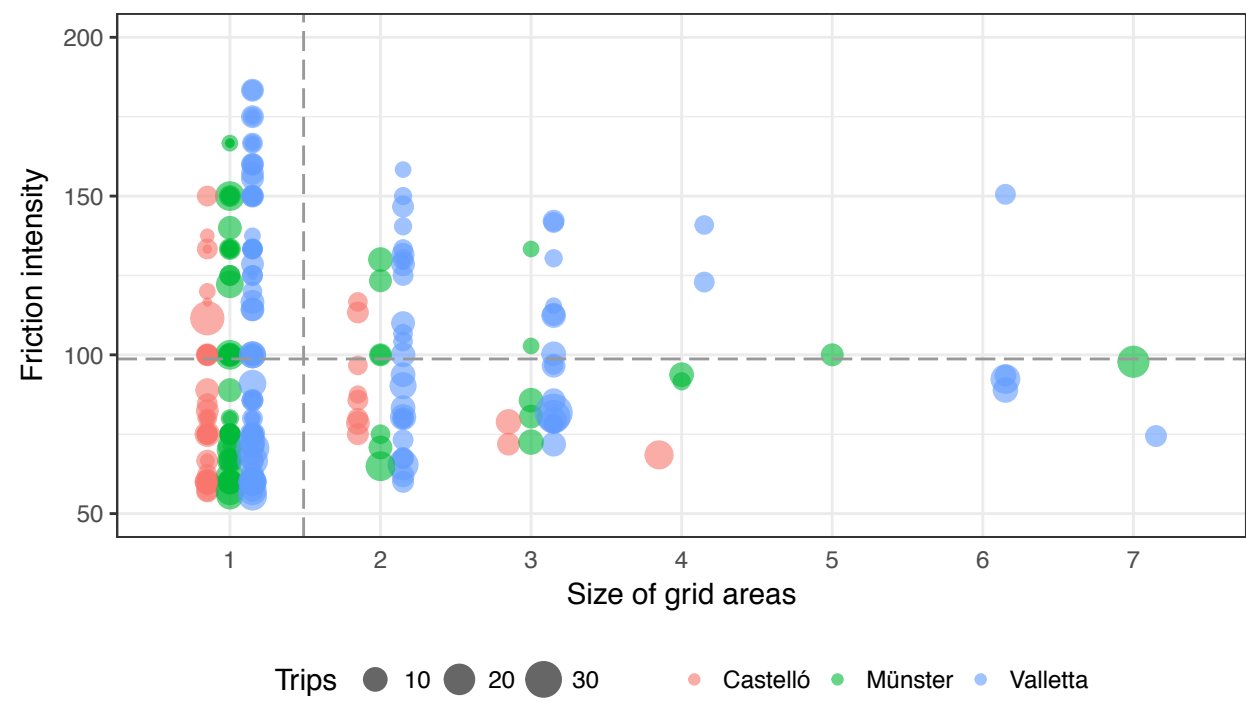

Figure 4.4: Aggregated third level frictions intensity and size.

The grid areas at the top right quadrant (33 grid areas-GA) were bigger, 
with higher intensity and mostly present in Valletta (24 GA out of the 33). The grid areas at the top left quadrant (107 GA) were smaller but with high intensity. There were grid areas with high friction intensity at the three cities but in different proportions. Münster (35 GA with high fiction intensity - HFI), they were mostly at intersections controlled by traffic lights; in Castelló (29 GA with HFI), they were mostly at intersections, roundabouts and the pedestrianised downtown; and in Valletta (76 GA with $\mathrm{HFI}$ ), they were mostly across streets with steep slopes, street intersections and grade separations. Our results combined the analysis functions and a visual examination for describing the cycling environment producing frictions.

\subsection{Spatial distribution of frictions}

We covered each city study area with the hexagonal grid as a way to spatially aggregate or bin the number of trips. By doing so, we extended our results beyond traditional maps of cyclists' preferred/non-preferred streets and focused on places inhibiting cyclists movement, especially those with a higher friction intensity shown in Figure 4.4. Our approach combined the conventional cycling representation of bicycle trips, see Figures 4.5, 4.6 and 4.7 top, with the iterative definition of frictions. We selected the areas where participants not only walked but also where the walking segments were much more compared to cycling segments to define the third level frictions (see Figures 4.5, 4.6 and 4.7 centre and bottom).

Extending the traditional visualisation of bicycle trips adds a new instrument to evaluate cycling conditions. The different perspectives seen in Figures 4.5, 4.6 and 4.7 show not only the cyclists' preferred streets but also the places where such activity was probably constrained. The frictions in Figures 4.5, 4.6 and 4.7 centre and bottom indicate places where participants not only cycled but also decreased their speed or stopped during their trips. Level three frictions excluded the grid cells having either origin or destination to ignore areas where participants walked to start or end a trip.

We compared the third level friction across the three cities regarding the size of the grid areas and friction intensity (see Figure 4.4). However, the use of geospatial analysis allowed us to compare the spatial distribution of frictions as well as the infrastructure and environmental conditions potentially constraining cycling. While in Valletta frictions were associated with the steep slopes faced by participants, the different cycling environments in Münster or Castelló produced other kinds of 


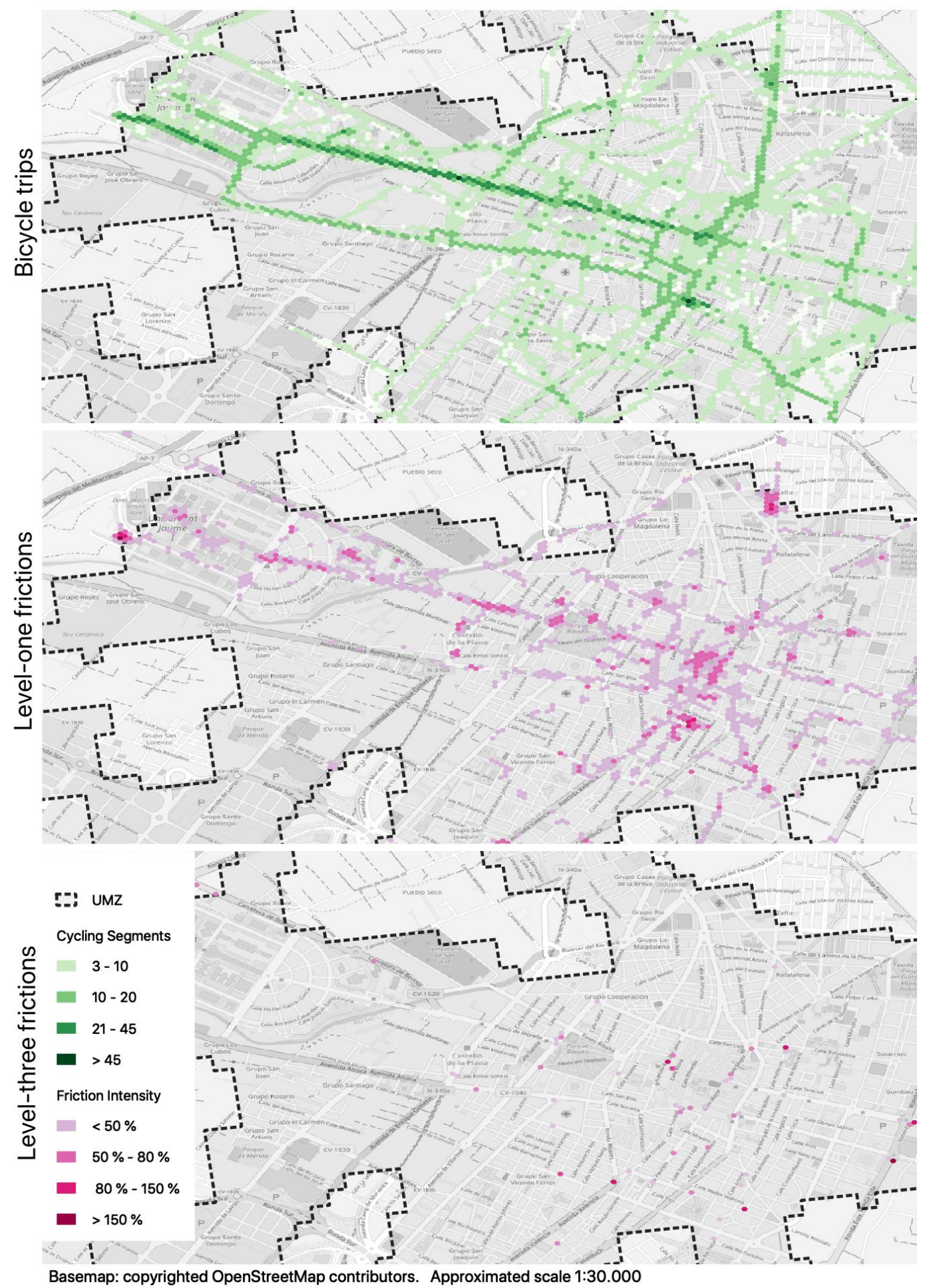

Figure 4.5: Castelló. Bicycle trips, first and third level frictions. 


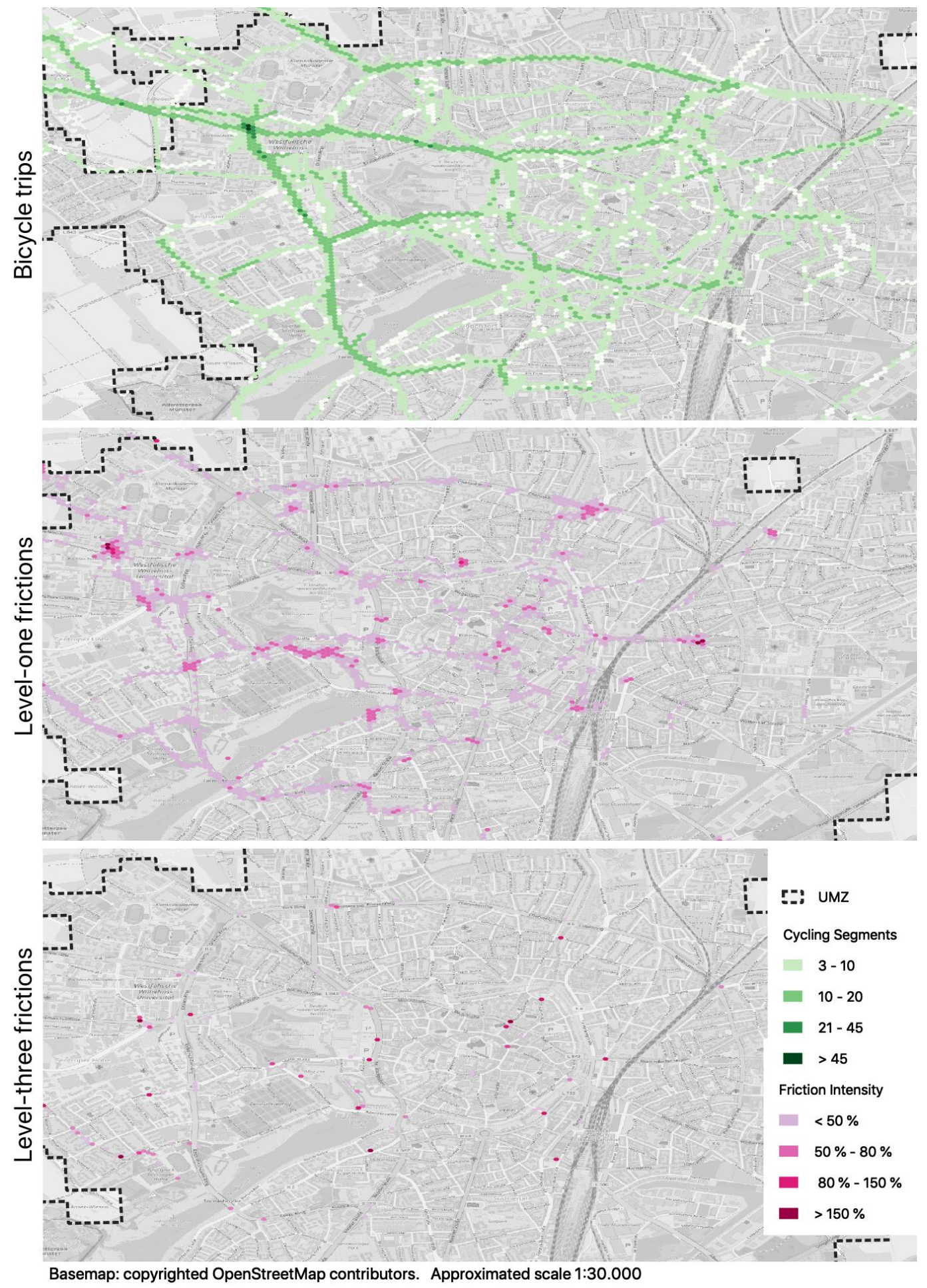

Figure 4.6: Münster. Bicycle trips, first and third level frictions. 


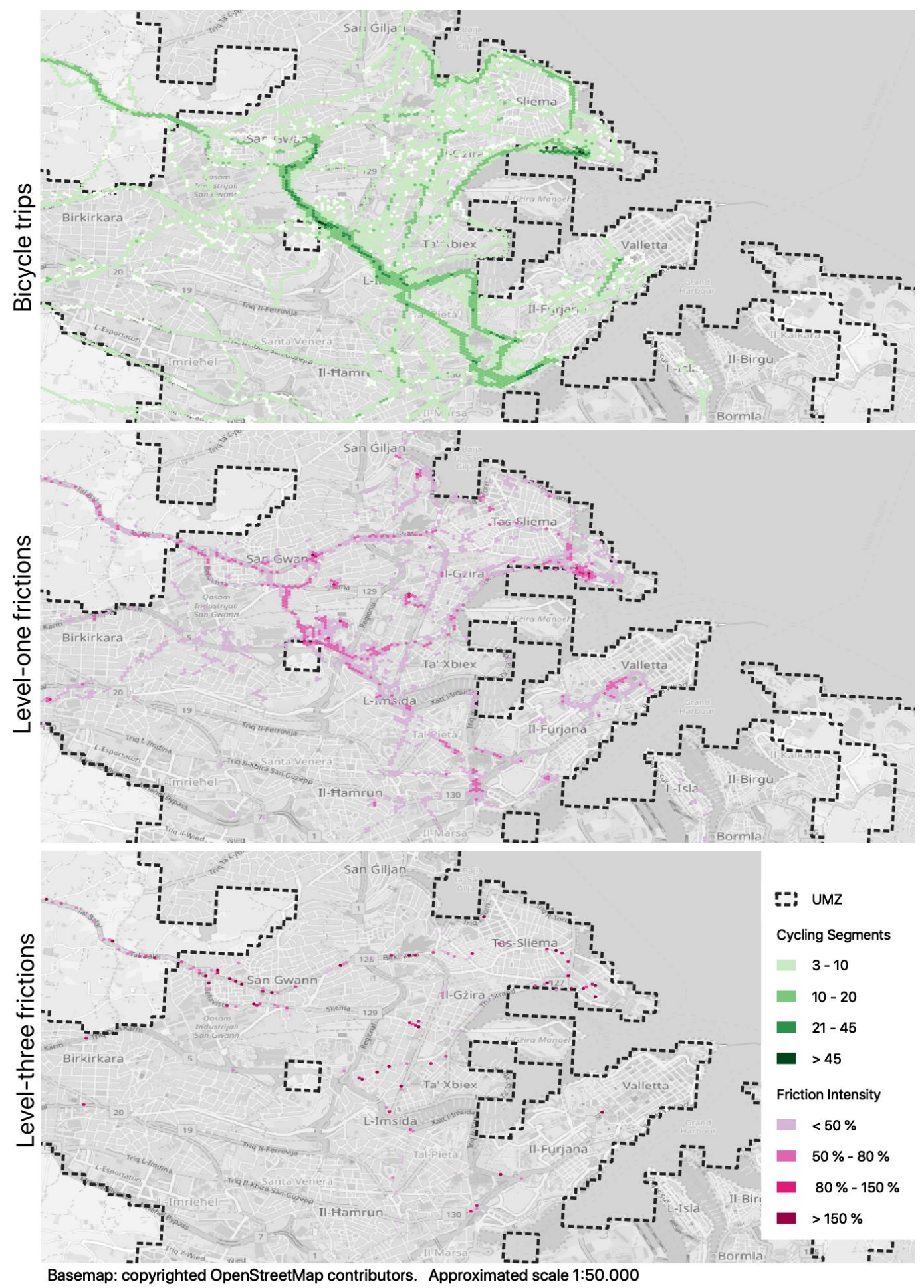

Figure 4.7: Valletta. Bicycle trips, first and third level frictions. 
distribution.

We linked the third level frictions with a series of four typical scenarios: particular cycling constraints, street intersections, city-specific intersections, and landmarks. Figure 4.8 shows a selection of third-level frictions as red polygons, the recorded trips using green lines, the bicycle paths in blue, and the surrounding map to understand the elements producing the calculated friction intensity. In Münster, we found frictions at places where participants moved from a dedicated bicycle path to a local street usually at a closed turn, at the intersections with highways, or at some crowded areas surrounding the city lake.

In Castelló, we found frictions at bicycle paths with cumbersome turns, roundabouts, or at the main city park entrance which served as a junction between the city centre and the avenue leading to the train station and university campus. In Valletta, we found frictions usually at streets with steep slopes surrounding the university campus, at huge grade separations such as the underpass leading to the university, and at some landmarks around the seashore promenade.

\subsection{Bicycle paths and bicycle commuting}

Although we found participants from Münster using more bicycle paths per trip than participants from Castelló, cyclists in Castelló recorded longer use of the paths. In Münster, participants recorded $235.5 \mathrm{~km}$ in bicycle paths which represented $76.8 \%$ of the cycled distance. In Castelló, participants recorded a slightly longer distance of $265.9 \mathrm{~km}$ which only represented $47.8 \%$ of the cycled distance. Apart from being a contradiction, these numbers and Figures 4.9, 4.10 and 4.11 on the one hand as trajectories in the map and on the other as vertical bars in the chart, show two different cycling scenarios. First, a scenario with more commuting trips using the city's high-quality cycling network in Münster (See Figure 4.10. Second, a scenario with lower coverage of bicycle paths in Castello but longer trips to either connect urban areas or to practice sports cycling (see Figure 4.9).

The case of Valletta radically differs from the other cities. In addition to the absence of bicycle paths, we found some cycling along the streets planned for bicycle paths in the future. Participants only recorded $95.7 \mathrm{Km}$ which represented just $28.8 \%$ of the cycled distance. In this case, the numbers and representation of Figure 4.11 only aim to serve as a reference point for future studies. 

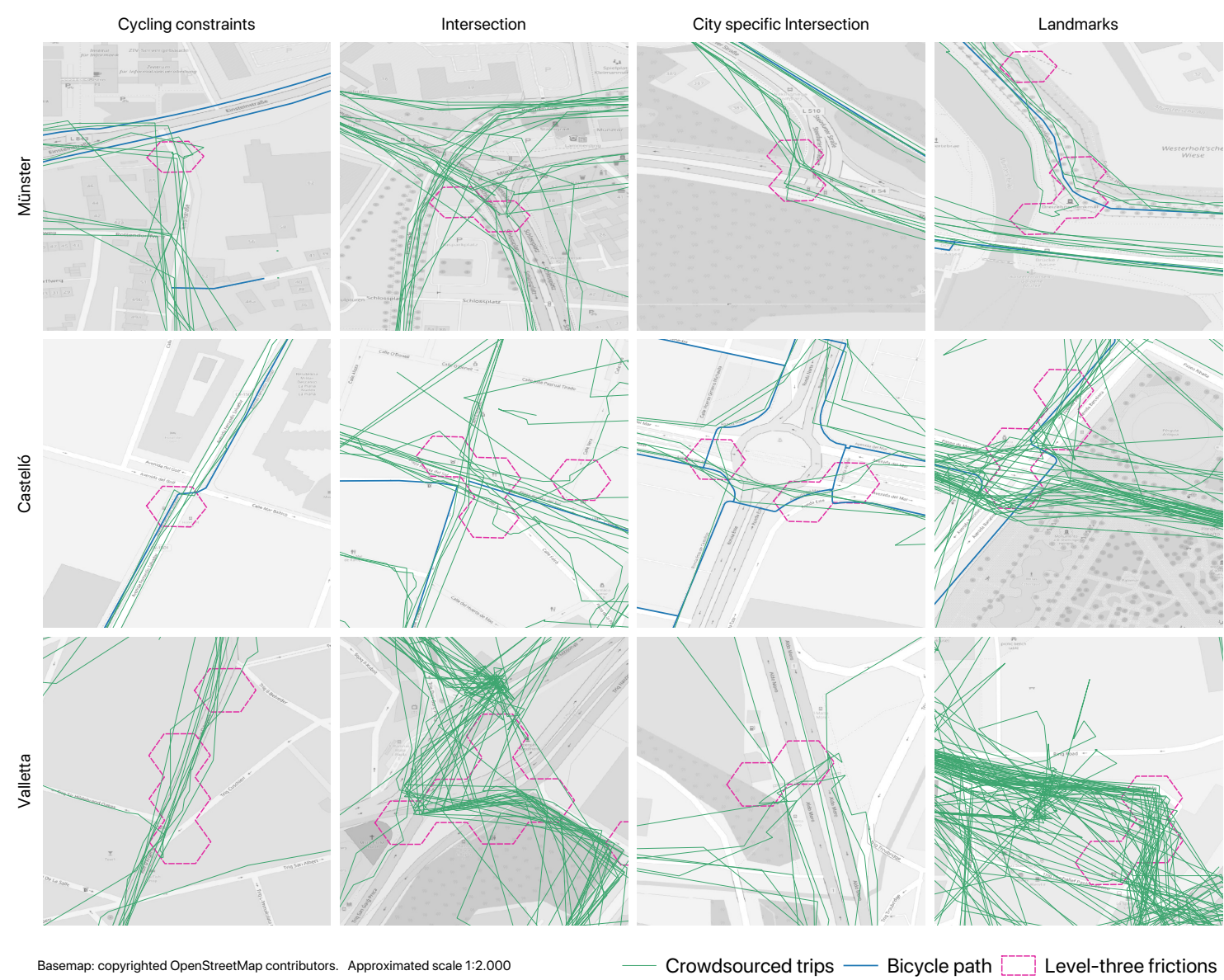

Figure 4.8: Four typical scenarios for third level frictions.

Most of the cycling related literature and numerous urban planners portray bicycle paths as enablers of urban cycling. Therefore, we tried to provide tools to evaluate the differences in cycling patterns produced by such paths. We counted the trips recorded at each bicycle path and mapped them to see the bicycle paths used during the experiment. Figures 4.9, 4.10 and 4.11 show the bicycle paths in blue, in green the paths with at least one trip recorded during the experiment, and in red the segments recorded off a bicycle path. Most of the cycling segments recorded off a bicycle path were at city centres, generally quiet or pedestrianised areas in Münster and Castelló. In Valletta, the majority of trips were off the planned bicycle network and some at the surrounding streets which are not part of the future network-plan.

We also analysed the cycled distance in bicycle paths per day of the week, 


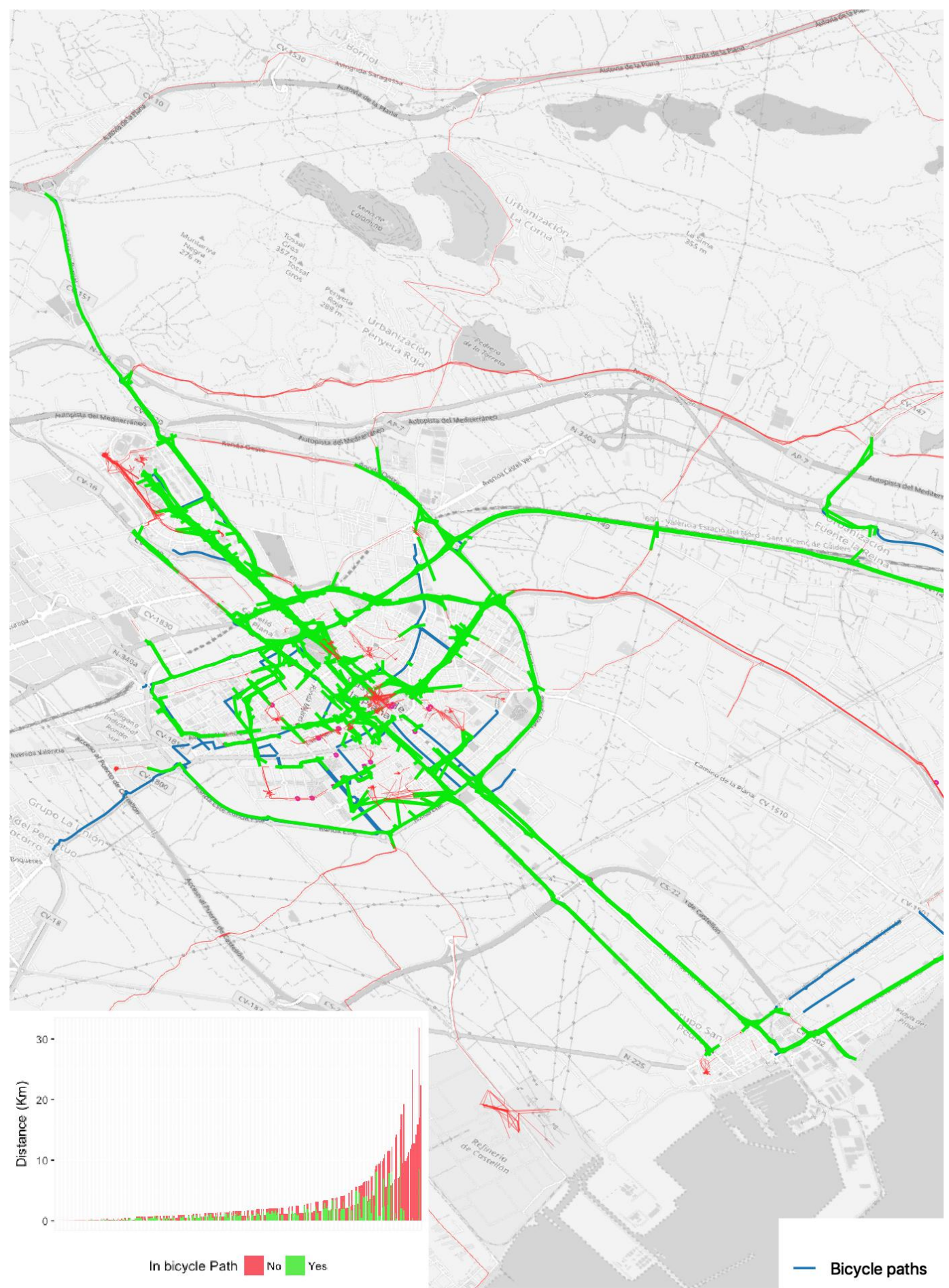

Basemap: copyrighted OpenStreetMap contributors. Approximated scale 1:50.000

Figure 4.9: Castelló. Cycled distance using bicycle paths. 


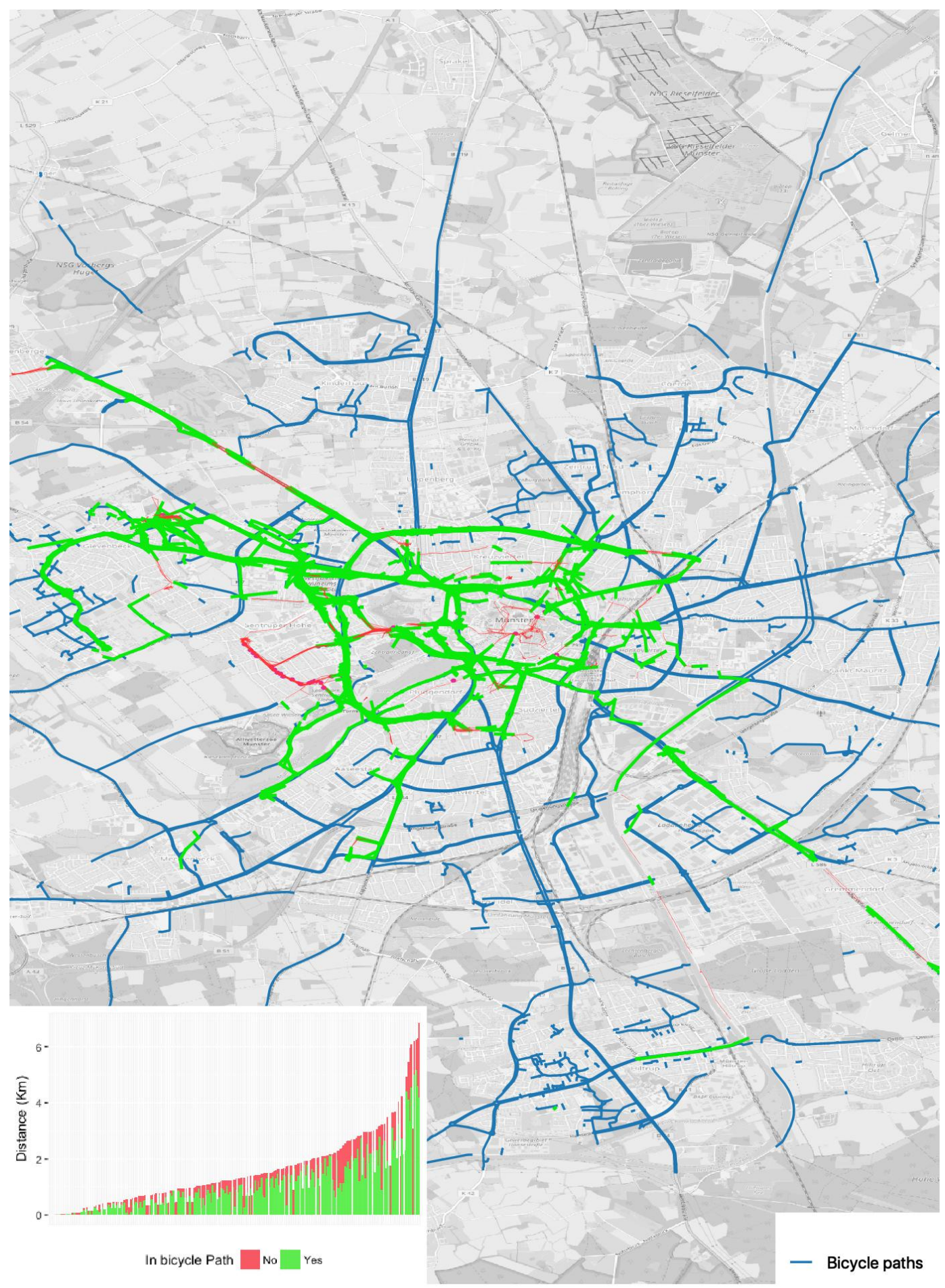

Basemap: copyrighted OpenStreetMap contributors. Approximated scale 1:50.000

Figure 4.10: Münster. Cycled distance using bicycle paths. 


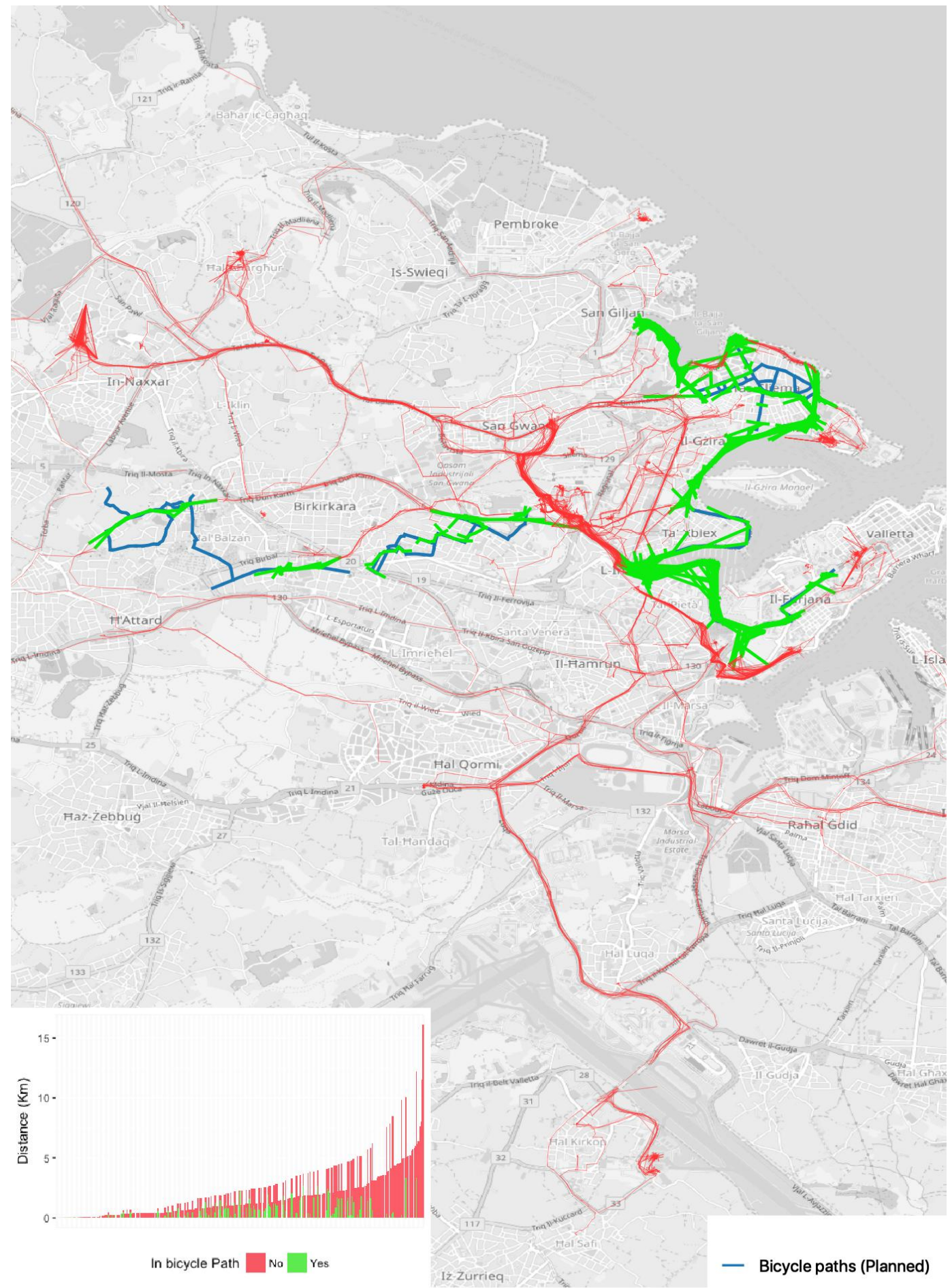

Basemap: copyrighted OpenStreetMap contributors. Approximated scale 1:50.000

Figure 4.11: Valletta. Cycled distance using bicycle paths. 


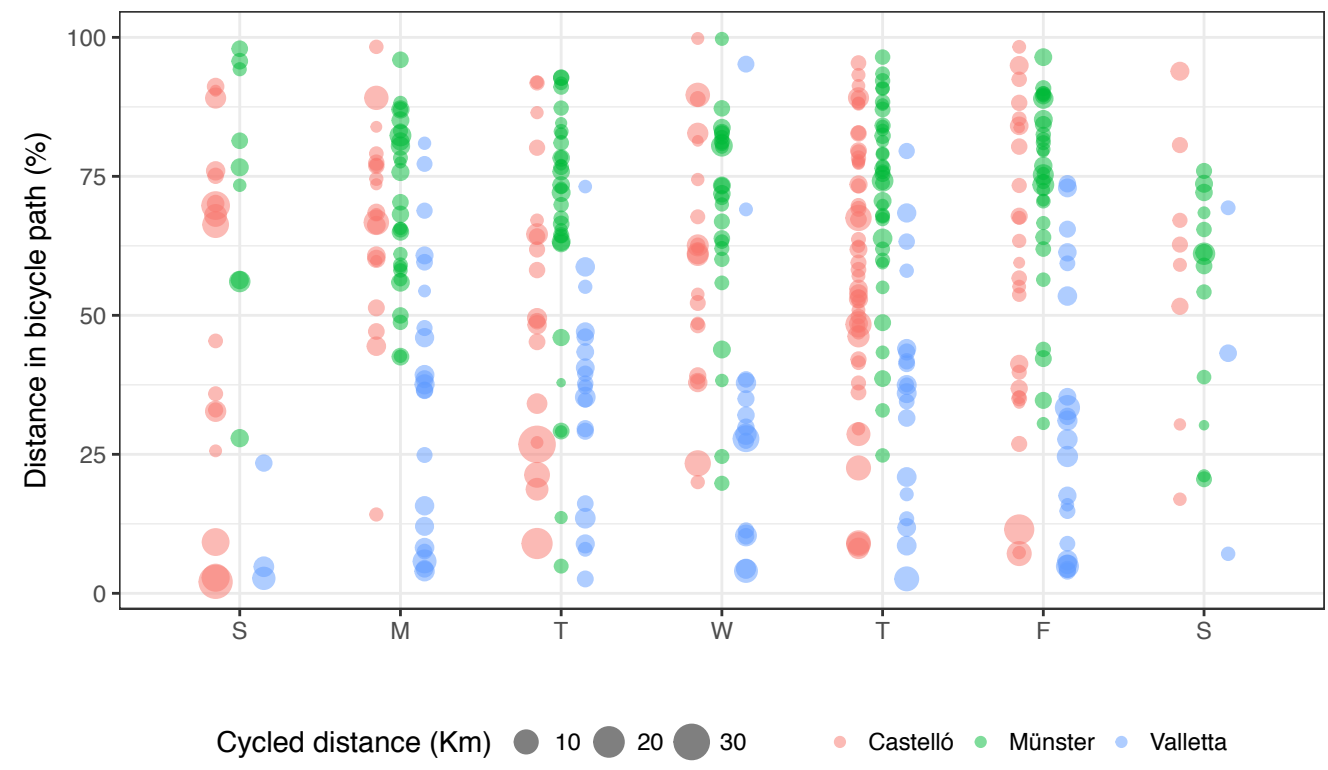

Figure 4.12: Cycled distance, proportion per trip.

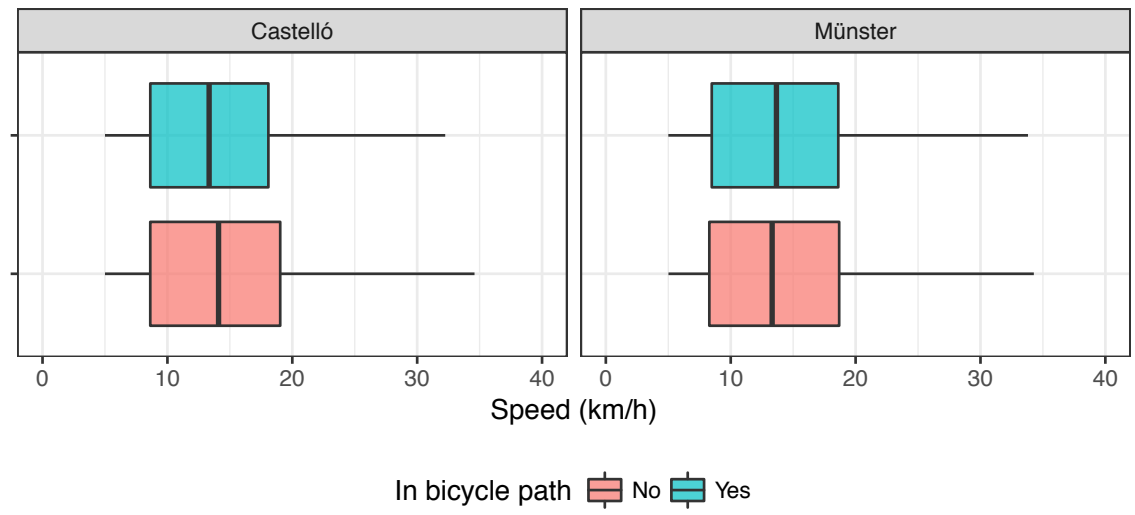

Figure 4.13: Average cycling speed and bicycle paths.

seen in Figure 4.12. Participants from Münster cycled mostly on bicycle paths and during work days. Participants from Castelló did not have a clear pattern beyond the low number of trips recorded on Saturdays. Participants from Valletta cycled mostly during work days and rarely used the streets planned for building bicycle paths.

Cycling speed is a proxy for the convenience of bicycle paths. Therefore, we compared the average cycling speed of segments recorded on and off bicycle 
paths. Figure 4.13 shows a box-plot graph with the average cycling speed. In Münster, there was a slightly higher cycling speed on bicycle paths while in Castelló there was a lower speed off the bicycle paths. Such a difference could come from participants from Castello cycling more for sports purposes and out of the urban areas. Although we did not find statistically significant differences and could not conclude on the convenience of bicycle paths, the comparison of cycling speeds deserves additional analysis and demands field-work validation.

\subsection{Summary}

In this section we successfully identified 284 places with potential frictions inhibiting bicycle commuting: 71 in Münster, Germany; 70 in Castelló, Spain; and 143 in Valletta, Malta. Participants at those places recorded bicycle trips, and we found the segments recorded at low speeds which indicated a deviation from an ideal cycling scenario. We selected and merged the grid cells with friction intensity between $50 \%$ and $200 \%$ to define the third level frictions. We, therefore, described the frictions based on the surrounding infrastructure, and the location within the urban area.

Our contribution included a crowdsourced dataset of bicycle trips from three European cities and analysis tools to identify the frictions inhibiting bicycle commuting. The use case presented contributes to the current trend of analysing bicycle commuting and serves as a reference for cities willing to evaluate its cycling environment. However, due to the limited number of participants, our results reflect only the participants' behaviour and cannot be generalised to a city level.

The experimental setup is suitable for analysing crowdsourced datasets coming from mobile phones and to describe the frictions inhibiting bicycle commuting. The use of a grid-based analysis and a common framework for the urban areas guaranteed the comparison between cities. Finally, it expanded the traditional analysis of individual bicycle trips by spatially aggregating them into units out of the streets such as open spaces or pedestrian areas. 



\section{Chapter 5}

\section{Benefits of cycling data and geospatial analysis for open cities}

This chapter discusses further insights and implications of the results achieved in the present thesis. In particular, we combined the results presented in the last two chapters to answer the research question number 3 and observe how geospatial analysis on crowdsourced cycling data can help to improve the cycling environment. The following discussion considers the role of mobile devices in encouraging bicycle commuting and the spatial footprint of cycling profiles and emphasises the lessons learned from urban cyclists during the experiment. Figure 5.1 summarises this final discussion as an iterative procedure with the following actions: crowdsourced data collection through mobile phones, city compilation of cycling data, analysis of cycling conditions including the frictions inhibiting cycling, and the promotion of bicycle commuting. Such a process would hopefully increase citizens' participation, feedback the overall process and help to improve cycling conditions.

We started from the cyclist's perspective, see Figure 5.1 top, where urban cycling is a relevant case study of behavioural change strategies and its analysis using geoinformatics. We commented on how mobile devices help to encourage people to increase cycling, or other physical activity, and the current research adding a geospatial context to engage more people with cycling. Moreover, we described the advantages of using collaboration-based rewards in gamified tools for cyclists and the lessons learned from participants recording cycling trips for this research. 
We therefore complemented the discussion with the city's perspective, see Figure 5.1 bottom, were geospatial analysis helps with an understanding of cycling conditions and supports policy-making. We use bicycle paths and participants' genders to describe the differences in cycling patterns. We also described the differences between participants already using cycling applications from the answers to the questions "Do you use any application when you are cycling?" and "If YES, which of the following do you use?". Based on the answers to these questions, we spatially represented the trips for each group and visually analysed the spatial features of cycling.

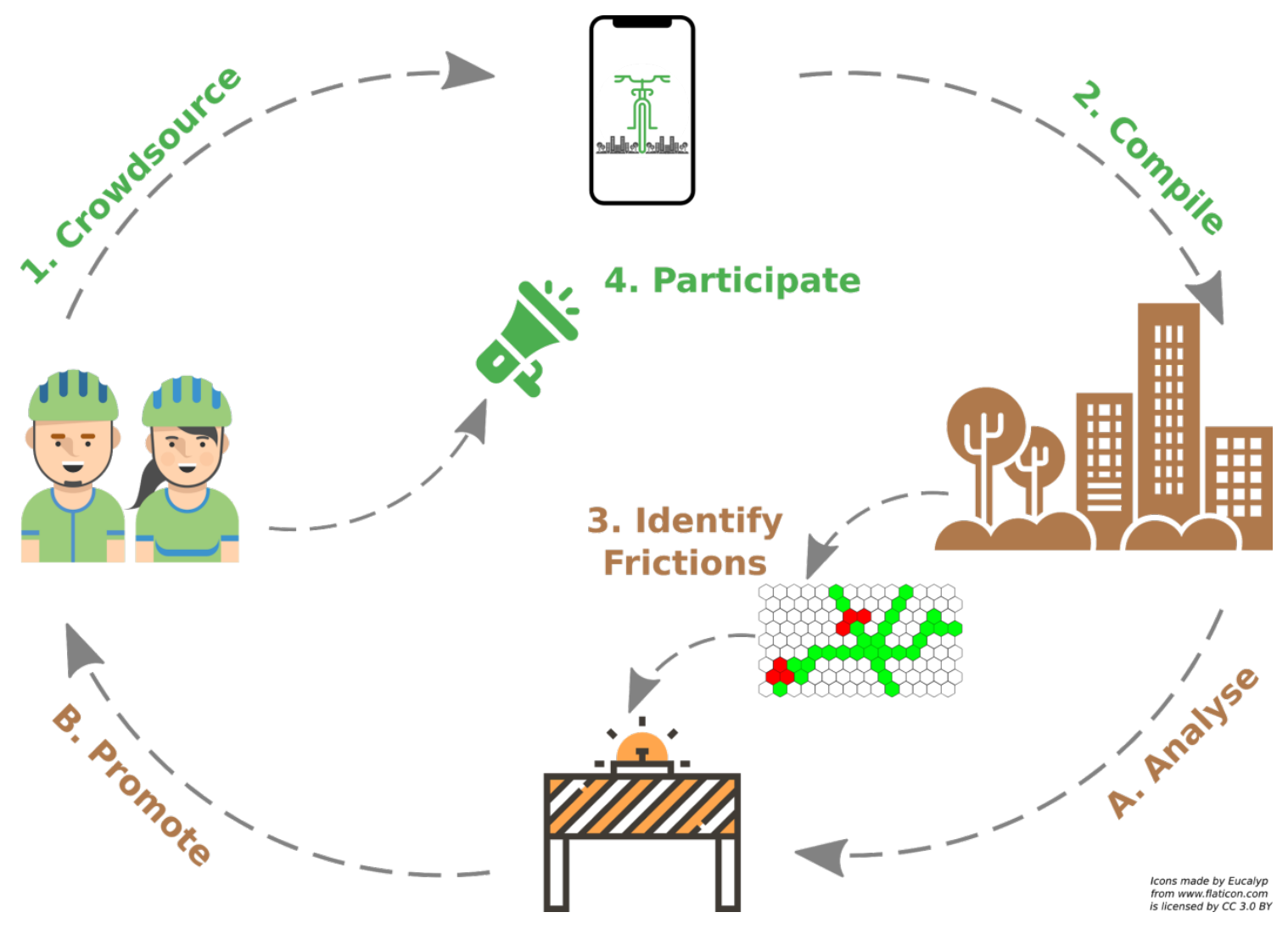

Figure 5.1: Mobile gamified tools and geospatial analysis benefiting open cities. 


\subsection{Encouraging bicycle commuting through mo- bile devices}

Mobile gamified tools for cyclists should target a particular community to gain relevance and offer site-specific feedback about the cycling environment (e.g., weather conditions, pollution, safety, comfort, congestion, cycling infrastructure, etc.). We considered the positive experiences of companies encouraging the use of bicycles among their employees, reported by Wunsch et al. (2016) and te Brömmelstroet (2014), after targeting particular communities. Considering participants' positive perception of group achievements in the two experiments mentioned, we focused our experiments on communities such as workers or students due to their role in the promotion and adoption of urban cycling.

Our literature review in chapter 3 revealed the current potential, challenges and limitations of mobile and gamified technologies to encourage cycling and physical activity. Within the 140 publications reviewed there was a balance between those reporting on experiments and literature reviews. However, the cycling-related publications mainly reported experiments with mobile technologies; half of them used LBS, and three-quarters used mobile devices. The reviewed studies which informed informed participants either with performance measurements (e.g., cycled distance, average speed or calories burned during cycling) or the environmental benefits of cycling (e.g., CO2 emissions or the pollution prevented) but not with concrete information related to urban transportation or commuting.

To deal with their own testing variables, researchers usually experimented with tailor-made solutions instead of the popular cycling applications. There were only three exceptions in the review (Berger and Platzer, 2015; Engineering and Technology, 2016; Navarro et al., 2013) which used the commercial platforms Moves, SmartMo and Social Cycle, and positively evaluated users' behavioural changes and perceptions after using them.

After asking participants of our experiment about their interaction with cycling geo-games, they mainly used mobile devices for communication rather than for playing mobile games. They reported using their mobile phones for "Basic applications and messaging" (94.7\%), "Reading news" (64.9\%), "Productivity applications" (40.4\%), and, few of them, (19.3\%) for "Mobile games". Since more than half the participants (60\%) already used mobile applications for cycling, they 
not only found our geo-game below their expectations but also felt that it added a cumbersome task to their routine. However, since neither Strava nor any mobile application reported by participants focused on urban cycling, we could not infer wheter they recorded cycle commuting rather than sports activities.

Current mobile applications for cyclists usually integrate competition-based rewards such as virtual points, badges, leader boards, and social interactions to engage users (Barratt, 2017; Wolff et al., 2017). Thus, the high popularity of ready-to-use gamified functionalities based on competition, developers and companies demonstrates how such tools are considered as an already proven strategy (Millonig, 2015). Due to the purpose-specific design and constant use of customised tools instead of commercial applications in research (Pajarito and Gould, 2017b), we aimed to highlight the capabilities that can be added by geospatial technologies to support user engagement, citizen participation, policy-making, and location-based games (Basiri et al., 2016; Sileryte et al., 2016; Schlieder et al., 2006).

\subsubsection{Advantages of collaboration-based rewards for encour- aging bicycle commuting}

After our experiment presented in Chapter 3, we found collaboration-based rewards potentially better than competition-based rewards when designing gamification strategies to engage citizens with bicycle commuting. We started with a literature review which portrayed playfulness and fun beyond competition and described additional sources of motivation used in behavioural change strategies, such as flexibility, freedom, or well-being. Unfortunately, mobile technologies to promote urban cycling usually omit complementary sources of intrinsic motivation despite their benefits (te Brömmelstroet, 2014). Particularly, the idea of crowdsourcing cycling data collection and citizens contributing to understanding mobility was neither a research trend in that review nor a commercial interest.

From our analysis with collaboration-based and competition-based rewards, we observed different levels of engagement with cycling in the two experimental conditions. Participants from the collaboration condition seemed slightly more engaged with cycling because of the higher number of trips recorded during the first two weeks, while participants from the competition condition tended to record more trips even after the experiment. The collaboration-based rewards expressed 
as the data contribution to the geo-game produced higher levels of satisfaction and engagement with urban cycling than competition-based rewards. Besides, there were higher levels of agreement with finding "collaboration" more enjoyable than "competition" which confirmed our hypothesis and provided insights into the convenience of collaboration-based gamification. The described results evaluating the impact of virtual rewards in urban cycling led us to consider collaboration as a relevant source of motivation for urban cyclists.

We saw the effect on participants of using our geo-game as a positive reaction that cities might consider in the future but, at the same time, we would prefer cities having stronger communities of urban cyclists which motivate data collection. During the experiment, participants created a substantial high-quality dataset of bicycle trips useful for analysing cycling patterns. However, regarding the effectiveness of our geo-game in actually persuading participants to change their behaviour, we found that interacting for just one week with a mobile application may not be enough to change participants' worldview of cycling as a regular mode of transport. Comparing such results with long-term interventions producing behavioural changes towards cycling, such as that described by Wunsch et al. (2016), we consider collaboration-based incentives deserve more attention from researchers (and practitioners) on persuasive technologies for urban cycling.

\subsubsection{Providing a geospatial context to urban cyclists}

Many smart city definitions emphasise the intense presence of IT and its capacity to reveal hidden patterns (Townsend, 2013). A method focused on finding those hidden patterns, in our case the so-called frictions, therefore fits into the idea of enabling open and smart cities (Degbelo et al., 2016b a). Considering the relevance of transport systems for moving people, goods and social interaction (te Brömmelstroet, 2014), technology has not only become crucial when adopting sustainable transport but also when adding location context to citizen participation, civic engagement and data collection. Some relevant examples of technology supporting transport data collection were described by Armoogum and Dill (2015) and (Berger and Platzer, 2015).

In our literature review, we found cycling-related publications mainly reporting on data collection (Iwińska et al., 2018; Berger and Platzer, 2015; Norris, 2015) or trip analysis from bicycle sharing systems (Yang et al., 2018; Fishman et al., 2013). 
Contrary to our initial expectations, cycling analysis was far from demanding highperformance computing, probably due to the lack of massive datasets (Claudel et al., 2015). So far, most of the transport surveys pick up aggregated trip data, as the action of moving from point $A$ to point $B$, without considering the geographical dimension of human movements. This lack of spatial context for trips' trajectories motivated location-based surveys (Berger and Platzer, 2015).

Location-based technologies, especially GNSS, improved not only transport and cycling data (Smith, 2015) but also location-based functionalities, such as trip planning or shortest path estimation. Mobile devices commonly adopt such technologies but, when it comes to cycling applications for urban environments, they are not fully functional. Mobile applications for cyclists are still limited in certain cities as they consider only car-street networks, ignore connections with cycling infrastructure, or discard bicycle flexibility in pedestrian spaces (Chen et al., 2018). Geospatial technologies can enhance urban cyclists' experiences and support urban planning. Besides, crowdsourced cycling data can potentially improve urban transport analyses due to the higher volume and the broader spatial coverage of the datasets. We should therefore expect more cyclist-centred analysis of cycling conditions, multimodal integration or last-mile bicycle connections.

Although a few publications reported on using advanced spatial analysis or machine learning to identify urban cycling patterns, we consider that processing and visualising geometries could be a complex task. That was one of the reasons for calculating the deviation of crowdsourced bicycle trips against an ideal cycling scenario. We described the frictions inhibiting bicycle commuting not only considering an expected cycled distance and speed but also the crowdsourced trajectories at walking speed. Our methodology, therefore, aimed to provide a feasible and reusable tool to identify cycling patterns from GPS tracks notwithstanding the small sample size.

The identified 793 bicycle trips and 284 frictions were one of the three main components of our methodology: the crowdsourced bicycle trips, the hexagonal grid, and the spatial aggregation of trips and segments. Despite the restrictions, we found our method convenient for processing crowdsourced cycling data and identifying cycling patterns in cities. The grid-based approach normalised the results, enabled comparison between cities, simplified data visualisation and supported both geographical and numerical comparisons at a cell level (see Chapter 2). 
Our analysis of bicycle trips relied on the concept of "friction" because we wanted to improve the visualisation of cycling patterns and locate the points inhibiting cycling activities. We also defined the friction intensity ratio, an objective geospatial indicator which synthesised the environmental constraints potentially inhibiting cycling.

We found in our methodological approach certain advantages of targeting bicycle commuters. The customised framework and the experimental design gave us insights into bicycle commuting in three European cities despite the different cycling environments. Also, the methodological approach helped to enhance descriptive statistics, spatially allocate cycling facilities, and simplify the complexity of cycling patterns as expected on a flow map (Claudel et al., 2015). Our research complements the existing techniques applied in transport geography such as feature matching or density estimation (Basiri et al., 2016), popular in cycling analysis and used for the Strava (2018b) or Wikiloc Outdoor (2018) applications. The result of our analysis (see Figure 5.2) provided insights into participants' commuter behaviour emphasising the spatial representation of crowdsourced bicycle trips and the frictions identified.

We documented the advantages of our methodological approach but, due to the small sample size of our experiments, we could not generalise from them or extend the results to the city level. The first of such examples was the comparison between our results, the Strava heatmap (Strava, 2018a) and the trips recorded using Wikiloc Outdoor (2018). In Figure 5.2 we found commuters cycling to connect towns and cities, not only for sports purposes. After linking bicycle segments and the closest bicycle path in Münster and Castelló, we found differences in the cycling speed in and out of such paths. We also found the temporal patterns of participants' trips distributed by day of the week and hour of the day in Figure 4.1. and used the grid layer to show not only the areas where participants cycled but also the places concentrating frictions inhibiting cycling in Figures 4.5, 4.6 and 4.7 .

The adoption of a common framework aimed to enhance the traditional perspective of transport engineering about urban cycling. First, extending visualisation from the numeric or non-geographical approach of traditional studies seen in Figure 5.3 and second, exploring the future of geoinformation and urban cycling research. However, that implementation also lacks fieldwork validation and data cleaning, a common limitation of data-driven analysis, especially when dealing with crowdsourced data generated with mobile phones or GPS devices. It means 


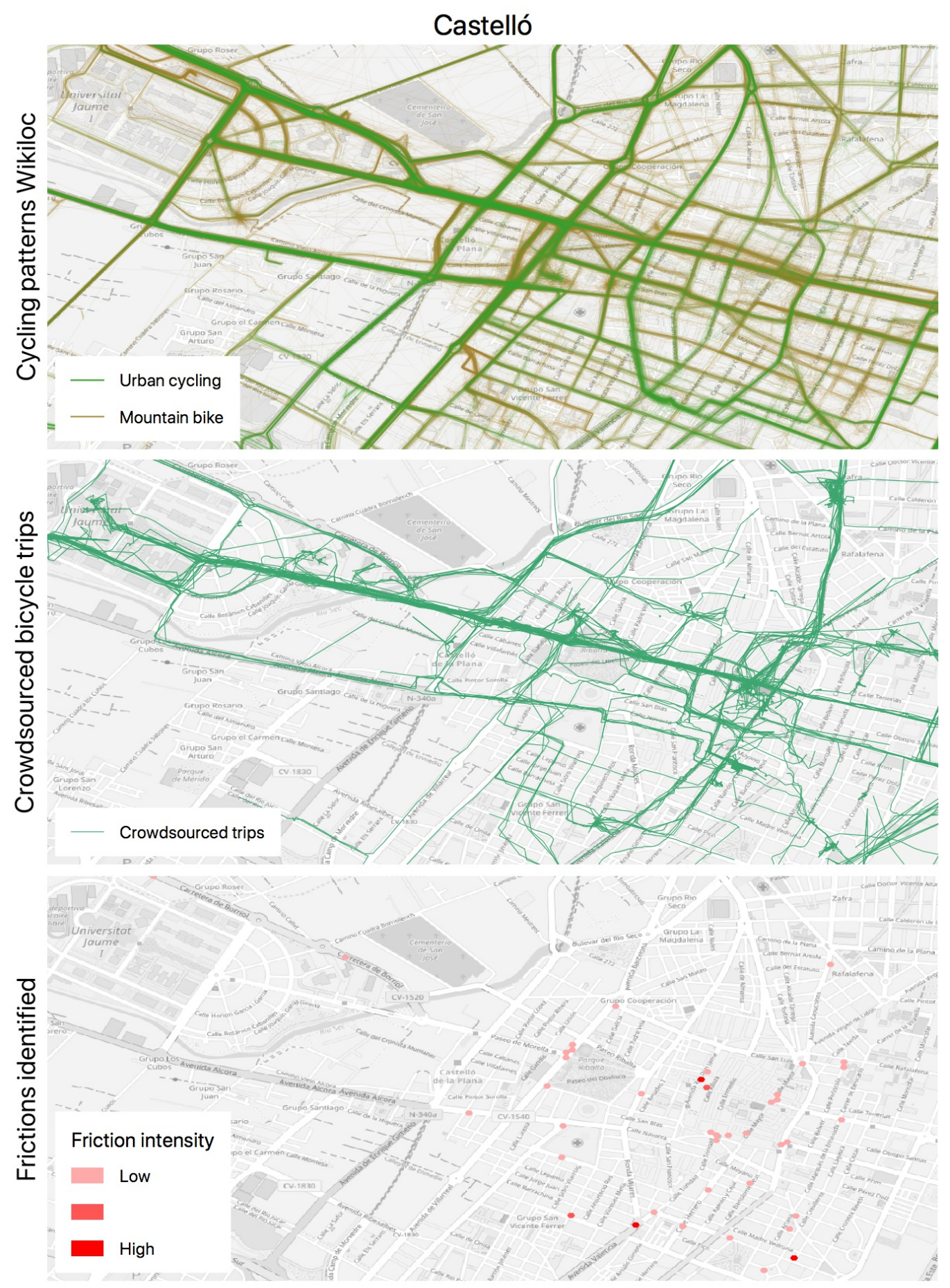

Basemap: copyrighted OpenStreetMap contributors. Approximated scale 1:25.000

Figure 5.2: Geospatial visualisation of cycling patterns and frictions. 
researchers trying to get a higher spatial resolution of cycling patterns should work on data cleaning to provide a better representation of bicycle trips, origins, destinations, modal shifts, and movement suspension patterns.

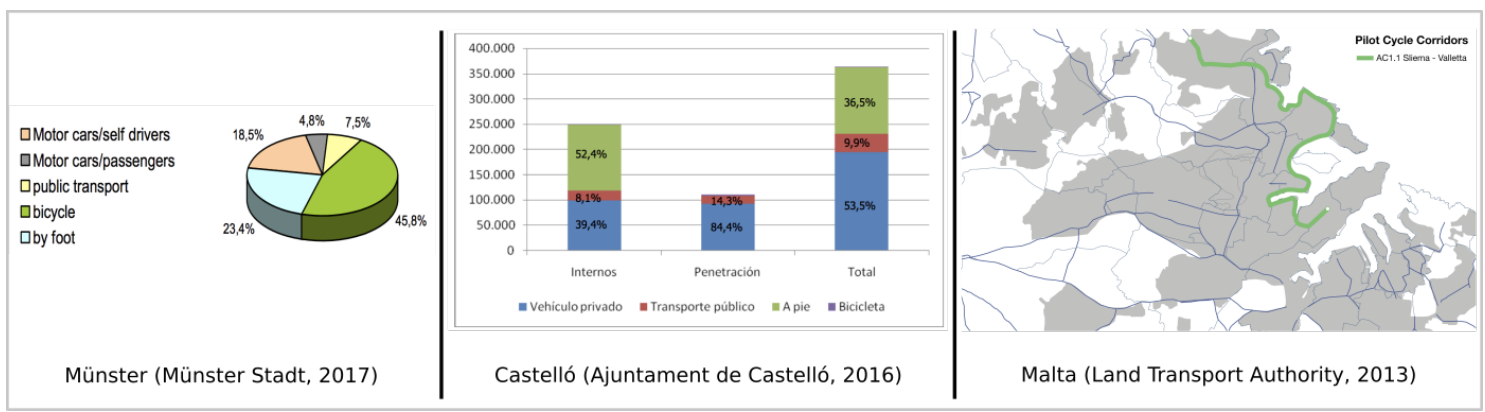

Figure 5.3: Data display examples from transport studies.

Our interdisciplinary approach linked three research topics: open cities, research reproducibility and citizen science. Our research scope not only fits into the idea of open cities (Degbelo et al., 2016b,a) but also considers open data as one of its relevant features (Benitez-Paez et al., 2018). It embraces citizens' claims for transparency and improvement of living conditions and frames them into the urban cyclist's perspective. We produced a set of tools and datasets freely accessible as part of the Open City Toolkit (see http://geo-c.eu/) using open data formats and open source components written in popular programming languages.

The idea of developing open reusable data and software components fits into the general trend of research reproducibility in geoinformation sciences (Nüst et al. 2018). Our research adopted "openness" in terms of reducing technical barriers to reuse our components and adopting Creative Commons licences (CC BY 4.0).

Our third link with citizen science followed the path described by Haklay (2013) and came after working with the cycling advocacy groups from the three cities and discovering the potential to evolve this crowdsourcing data collection. Through that work, we realised the current role of advocacy groups in urban cycling promotion and envisioned a level-two citizen science strategy which they can lead or support. The strategy would not only claim for smarter mobility systems but would also involve more cyclists in data collection, data analysis, or supporting decision making. Future work in such direction would complement the current experiences in different fields with citizen science and take advantage of its potential in transportation (Haklay and Weber, 2008; Attard et al., 2016; Basiri et al., 2016). 


\subsubsection{Lessons learned from urban cyclists crowdsourcing bi- cycle trips}

As this thesis merged quantitative (e.g., a short unstructured interview to participants before and after the experiment, open questions in the questionnaire) and qualitative methods (e.g., structured survey, spatial aggregation of geometries, descriptive statistics of trips, etc.) used by $\mathrm{HCl}$ and geoinformation sciences, we enriched our experience having interacted with participants and this is worth describing. Our research considered the relevance for cities of transport and urban cycling, evaluated the research gap on mobile technologies for cyclists and envisioned the interaction between individuals, mobile technologies and geospatial analysis. Thus our results encompass the accountability usually expected from engineering studies together with an explanation coming out from participants feedback.

One of the benefits of targeting bicycle commuters and working with officials from the city council of Castello was the direct feedback received. Therefore, we presented a reproducible and potentially sustainable research approach involving citizens' participation, urban analysis and entrepreneurship referring to the description of Bellotti et al. (2016) and McHugh et al. (2017).

The envisaged number of 20 volunteers at each city successfully participated within the foreseen time-frame and gave valuable qualitative feedback after the experiment. Participant feedback was useful for designing future mobile applications for urban cyclists. For example, they suggested personalised reminders not to forget trip recording, more customised tags and a map view of the recorded trips recorded in the city.

The general response of volunteers was very positive: they considered a similar application would potentially attract them or benefit their cycling organisation. Most of the participants were willing to share their location data and cycling movements for this study. Volunteers saw the value of using the application as a motivational tool, especially for beginners, for tracking their personal goals and, for advocacy groups, to support campaigning or lobbying for greater bicycle use.

There were two main sets of improvements coming from participants' feedback. One was related to improvements in the app functionalities, such as reminders, better control of trip recording and a more intuitive interface for adding tags. The 
other was related to the lack of much-needed functionalities such as the map of the cycling environment, using the mobile phone to locate infrastructure and sense its quality by combining the position and vibration measurements across the trip, or topography-based incentives (e.g., extra points for "climbing hills").

Based on the successful execution of the experiment and the feedback of 57 volunteers who used the Cyclist GEO-C app, we grouped the lessons learned into the following categories:

- A successful proof of concept. We deployed an experiment in three different cities, each with their user base and geography, culture and cycling facilities. Such deployment demonstrated the potential of mobile technology to help cities and citizens to understand the nature of urban cycling and promote it. However, to reuse our application it is necessary to create guidelines to adapt it to other contexts so that researchers, cycling activists, advocacy groups, decision-makers, or individuals can use or modify it for their particular purposes.

- Our approach can scale to Level 2 Citizen Science. The platform and the overall intention of citizen crowdsourcing and validating cycling patterns fit into the Haklay (2013) Level 2 Citizen Science category "Distributed Intelligence". Urban cyclists seemed willing to help with interpreting cycling patterns and framing further research, so it should also increase their engagement.

- Crowdsourced data can describe cycling patterns. Our application supported the crowdsourced cycling data collection in three different cities. Moreover, the analysis of the crowdsourced data provided insights into participants' cycling patterns and variables, such as their average speed, distance, preferred cycling days and times, use of cycle paths, as well as the frictions faced during the experiment. The participants' suggestions, such as geovisualisation of recorded trips, customised interfaces, or support for more sustainable transport modes, did not refer to data collection functionality but mainly to the application-user experience.

- A better understanding of cycling patterns demands fieldwork validation. Data collected with mobile phones and, in general, using untrained volunteers, requires cleaning and validation. Although researchers are capable 
of visually examining cycling patterns and algorithms can directly estimate values such as distance, speed, or the closest bicycle path; crowdsourced bicycle trips need further cleaning to feed more complex analysis. Complementary information and field validation will improve the analysis outcomes.

- Our approach lacks a sustainability model. Technically our mobile application can support a wider audience, more cities, or different modes of transport. Due to the existing deployment within the university (UJI) infrastructure, any additional support would require economic resources, managerial support and a leading organisation (e.g., university, research centre, national transport agency, research institute or a private company) to handle participant recruitment, technical maintenance of the platform, extended data storage, or processing infrastructure.

\subsection{The spatial footprint of participants' profiles}

We integrated the research outcomes from Chapter 3 and Chapter 4 to link the cycling patterns and participants' profiles. During the experiment, participants answered a questionnaire about their cycling preferences based on Pooley's questionnaire (Pooley et al., 2011), see Appendix B. The compilation of these answers brought up the comparison of cycling preferences between the three cities. However, we extended the traditional approach of mobile geospatial technologies, spatial analysis, and the spatial representation of cycling patterns to discuss the spatial footprint of such cycling profiles.

This integration brought up insights into the spatial features of male and female trips and participants using mobile applications for cyclists. Such spatial distribution also partially showed the cyclists' footprint in the city. The first set of insights dealt with participants' gender, bicycle paths and the use of cycling applications. These cyclists showed differences between the way female and male participants used bicycle paths, on the one hand, and how male participants reported greater intentions to record their bicycle trips and cycled longer distances at higher speeds on the other.

The second set of insights dealt with female and male participants cycling through different areas and participants using cycling applications cycling out of the urban areas, as well as the spatial distribution of trips' origins, destinations, 
orientation and distances cycled obtained after the spatial simplification of the recorded trips.

\subsubsection{Participants' reaction to bicycle paths and cycling ap- plications}

In general, female participants cycled more on bicycle paths when available than male participants, who cycled longer distances at a higher speed. Figure 5.4 shows crowdsourced trips as circles, participants' gender as colours, and female trips clustering slightly right, see $x$-axis. It meant female participants cycling more in a bicycle path especially in Castelló. In Münster, although all participants usually cycled between $25 \%$ and $50 \%$ of the trip on a bicycle path, we saw more female trips cycling more than $50 \%$ on bicycle paths.

The average cycling speed was in general between 10 and $20 \mathrm{~km} / \mathrm{h}$, but there were differences between male and female trips. Male trips, especially in Castelló, clustered top, which meant a higher average cycling speed, see $y$-axis. Moreover, trips covering longer distances clustered left (see the bigger circles), and came from male participants, who also used cycle paths less.

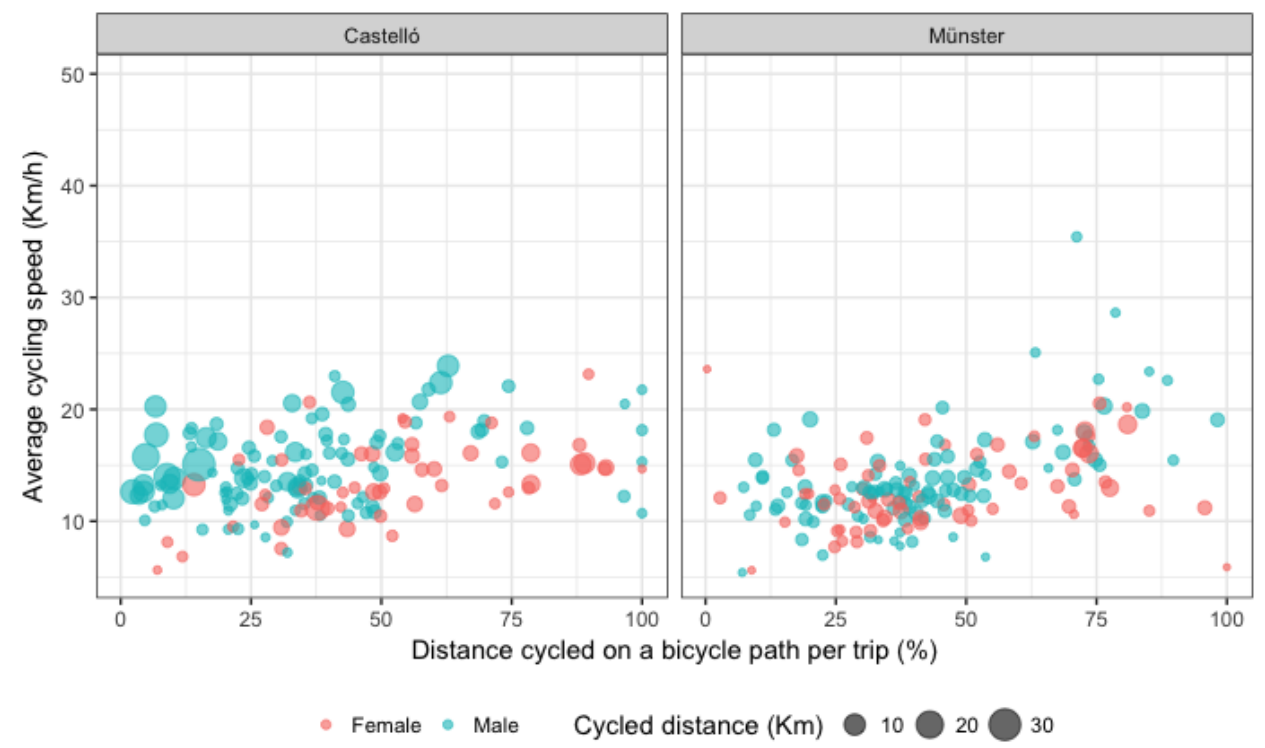

Figure 5.4: Trip distribution by cycling speed and distance cycled on a bike path.

We tested the differences between male and female trips and found statistically 
significant differences with the Wilcoxon test (Gehan, 1965). Table 5.1 shows female participants from Castelló cycling more on bicycle paths and male participants cycling faster, although in Valletta female participants cycled faster than male participants. In Münster, we did not find any statistically significant difference between male and female trips.

\begin{tabular}{|c|c|c|c|c|}
\hline & & $\begin{array}{l}\text { Cycled distance } \\
\text { in bike paths }\end{array}$ & $\begin{array}{l}\text { Average Cycling } \\
\text { Speed }\end{array}$ & $\begin{array}{l}\text { Average Cycling } \\
\text { Speed in a Bike } \\
\text { Path }\end{array}$ \\
\hline & Male: & $41.28 \%$ & $14.6 \mathrm{Km} / \mathrm{h}$ & $14.1 \mathrm{Km} / \mathrm{h}$ \\
\hline \multirow[t]{4}{*}{ Münster } & Female: & $44.99 \%$ & $13.3 \mathrm{Km} / \mathrm{h}$ & $13.2 \mathrm{Km} / \mathrm{h}$ \\
\hline & Wilcoxon & $W=3125$ & $W=4877$ & $W=3842$ \\
\hline & Test: & $\rho=0.433$ & $\rho=0.2112$ & $\rho=\mathbf{0 . 1 2 1 4}$ \\
\hline & Male: & $35.96 \%$ & $16.0 \mathrm{Km} / \mathrm{h}$ & $15.0 \mathrm{Km} / \mathrm{h}$ \\
\hline \multirow[t]{3}{*}{ Castelló } & Female: & $51.24 \%$ & $12.7 \mathrm{Km} / \mathrm{h}$ & $14.0 \mathrm{Km} / \mathrm{h}$ \\
\hline & Wilcoxon & $W=1722$ & $W=8453$ & $W=3135$ \\
\hline & Test: & $\rho=0.000055$ & $\rho=0.0008481$ & $\rho=0.2784$ \\
\hline Valletta & Male: & $2.52 \%$ & $17.0 \mathrm{Km} / \mathrm{h}$ & - \\
\hline (Without & Female: & $2.47 \%$ & $22.4 \mathrm{Km} / \mathrm{h}$ & - \\
\hline Bike paths) & $\begin{array}{l}\text { Wilcoxon } \\
\text { Test: }\end{array}$ & $\begin{array}{l}W=17504 \\
\rho=0.5814\end{array}$ & $\begin{array}{c}W=7640.5 \\
\rho=0.0004977\end{array}$ & - \\
\hline
\end{tabular}

Table 5.1: Gender comparison of cycling distances and speed.

We also explored participants' perceptions of common cycling constraints such as the need for more bicycle paths, parking facilities, safety conditions, the physical effort needed to cycle, the existing road conditions, junctions or intersections. From participants' answers, we found the negotiation at junctions or intersections in Valletta to be at the top of the constraints reported. Participants were neutral or disagreed with questions about parking, safety and the lack of bicycle paths as cycling constraints in general. Figure 5.5 shows three sentences about cycling constraints, see $y$-axis, against the level of agreement reported, see $x$-axis. Then we aggregated the trips according to the participants' level of agreement with each sentence.

For the sentence on "negotiating difficult road junctions", trips from Valletta clustered right, showing it as a constraint for participants, trips from Münster 
were clustered left, not showing it as a constraint, and trips from Castelló had no particular clustering. For the sentence on the "experience with existing roads", trips from Valletta and Castelló clustered centre-right, showing it as a constraint, and trips from Münster clustered centre-left, showing neutrality. For the third sentence on the "physical effort" needed to cycle, trips from all cities clustered left which meant such an effort is not a cycling constraint.

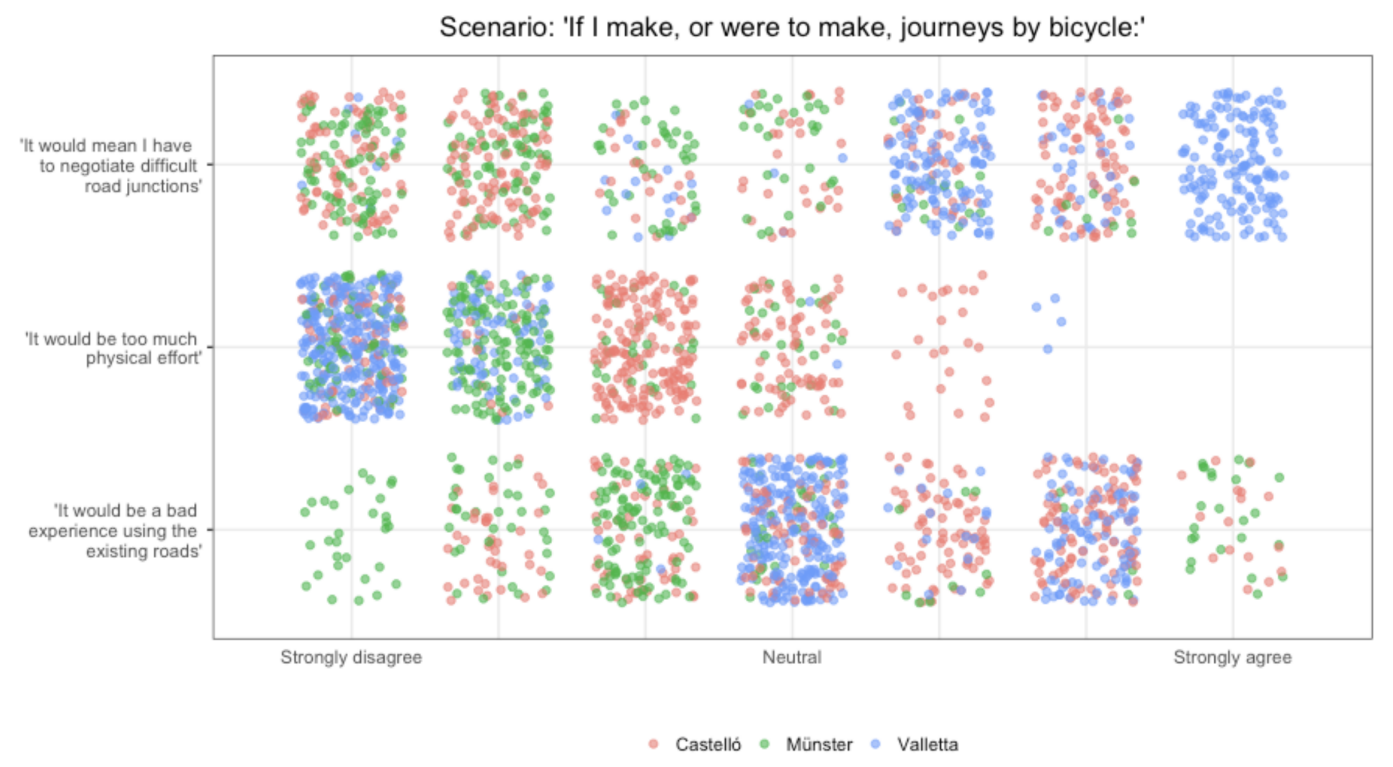

Figure 5.5: Cycling constraints and participants' perception of them.

As a complement to the findings on the use of bicycle paths and cycling constraints, we found male participants reporting stronger intentions to use an application while cycling, recording more trips and longer distances. Figure 5.6 shows intentions to use an application while cycling (see $x$-axis) against the distance cycled on bicycle paths, see $y$-axis. Then we aggregated the trips according to the participants' intentions, coloured by gender and sized by cycled distance. Figure 5.6 top shows female trips randomly distributed while male trips are clustered bottom-right, showing the strong intentions of male participants to use an application while cycling. Here again we see again male participants cycling longer distances (see the bigger circles) and using bicycle paths less (see y-axis).

Figure 5.6 bottom shows the sub-patterns per city. From left to right, participants from Castelló reported stronger intentions to use an application while cycling, participants from Münster were more neutral, and Valletta's participants split into 

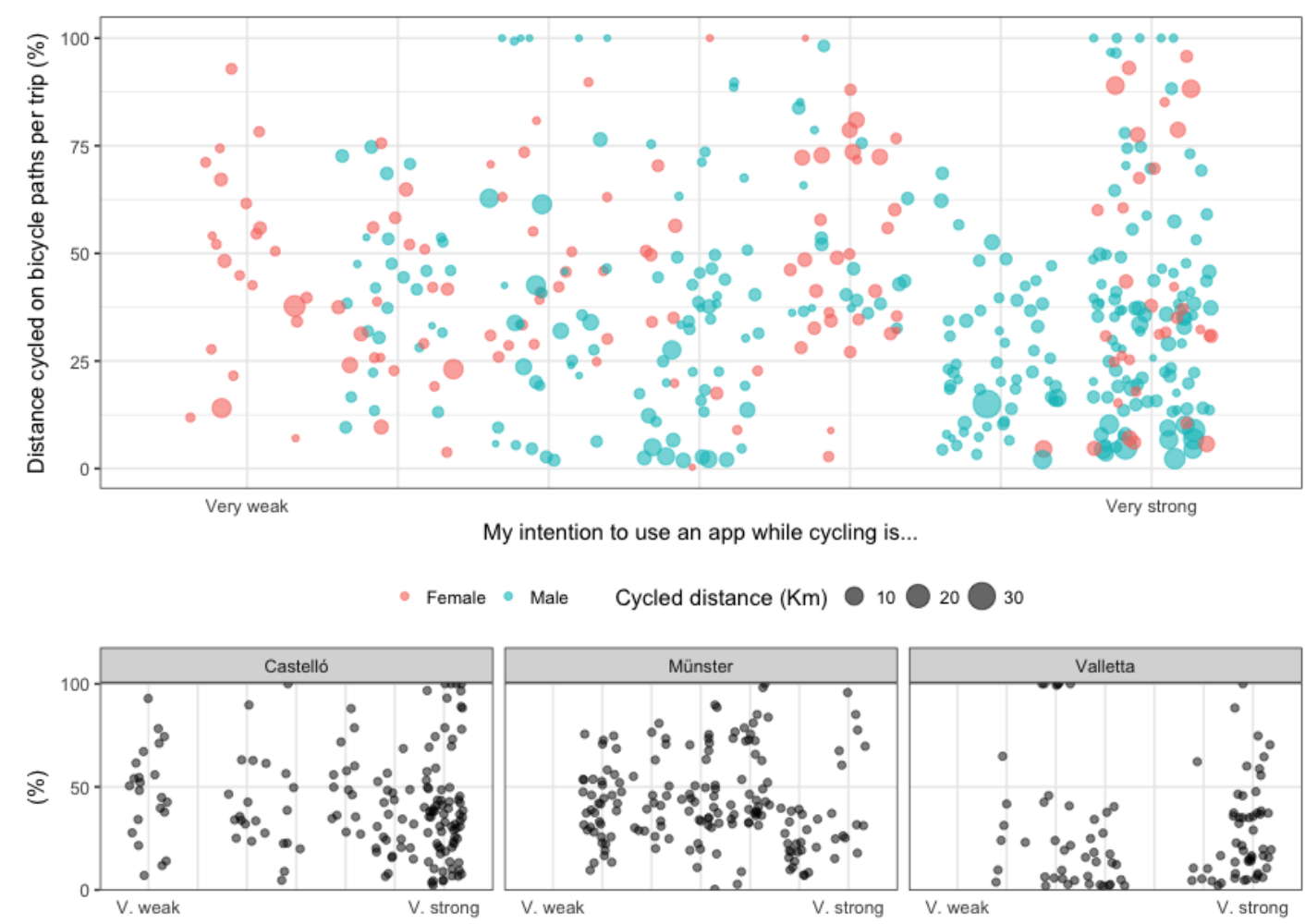

Figure 5.6: Intention to use an app while cycling and recorded trips.

neutral and strong intentions to use an application. The distance cycled on bicycle paths seen in Figure 5.6 at the bottom visually describes the values of Table 5.1. excluding the use of bicycle paths in Valletta, where there are none.

We found participants' reported intentions coinciding with the current use of mobile applications for cyclists, as the participants using cycling applications recorded more trips and longer distances. Figure 5.7 shows the intention to use an application while cycling (see $x$-axis) against the trip distance cycled (see $y$-axis) and the trips coloured if the participant reported using a cycling application. The trips by participants using a cycling application clustered right, showing their strong intentions to use cycling applications and the longer distances cycled, while trips from participants not using cycling applications clustered left.

We tested the differences between participants using any cycling application or not using them and found statistically significant differences with the Wilcoxon test (Gehan, 1965). Table 5.2 shows participants using a cycling application reporting different intentions, longer distances, higher cycling speed and more trips recorded 


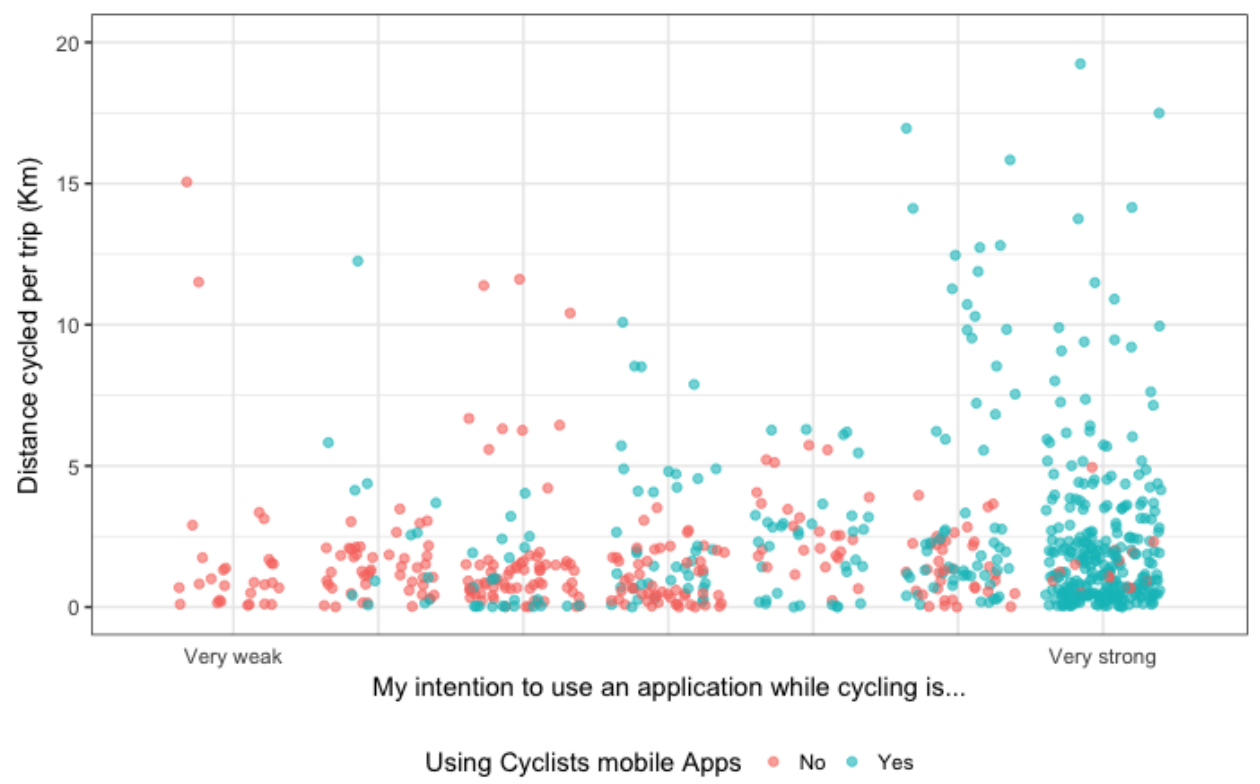

Figure 5.7: Participants' use of cycling applications and trips.

than participants not using it. The differences were significant especially in the average distance cycled which differed by more than $1 \mathrm{~km}$.

\begin{tabular}{lcccc}
\hline & $\begin{array}{c}\text { Likert scale value for } \\
\text { the question: "My } \\
\text { Intention to use an } \\
\text { app while cycling" }\end{array}$ & Distance & Speed & N trips \\
\hline $\begin{array}{l}\text { Using a cycling } \\
\text { Application }\end{array}$ & 1 & $2.64 \mathrm{Km}$ & $16.06 \mathrm{Km}$ & 550 \\
\hline $\begin{array}{l}\text { Not using a cyc- } \\
\text { ling Application }\end{array}$ & -1.172414 & $1.6 \mathrm{Km}$ & $14.57 \mathrm{Km}$ & 379 \\
\hline Wilcoxon Test: & $\mathrm{W}=580.5$ & $\mathrm{~W}=70127$ & $\mathrm{~W}=67245$ & \\
& $\rho=0.0001328$ & $\rho=0.000867$ & $\rho=0.0234$ & \\
\hline
\end{tabular}

Table 5.2: Differences between participants depending on whether they used cycling apps. 


\subsubsection{Spatial distribution of trips}

We found differences in preferred areas for cycling not only between female and male participants but also between those who used and those who did not use cycling applications. Concerning geometry, we identified how trip origins and destinations grouped, and the common orientation of recorded trips. To extend existing visualisation tools for cycling, such as the Strava (2018b) or Wikiloc Outdoor (2018), we chose gender and participants using cycling applications to explore the differences in the spatial distribution of trips.

Male and female participants usually cycled through different areas of the city. Figure 5.8 shows the trips recorded by male and female participants in different colours. In Münster, female participants usually cycled through the city centre while male participants cycled more through the rings enclosing it. In Castelló, male participants recorded most of the trips out of the city in the northern mountain area, but within the city we found female and male participants also connecting the university campus and city centre. In Valletta, we found a few more female participants cycling through a promenade facing the sea, but in general, we found no differences between female and male trips.

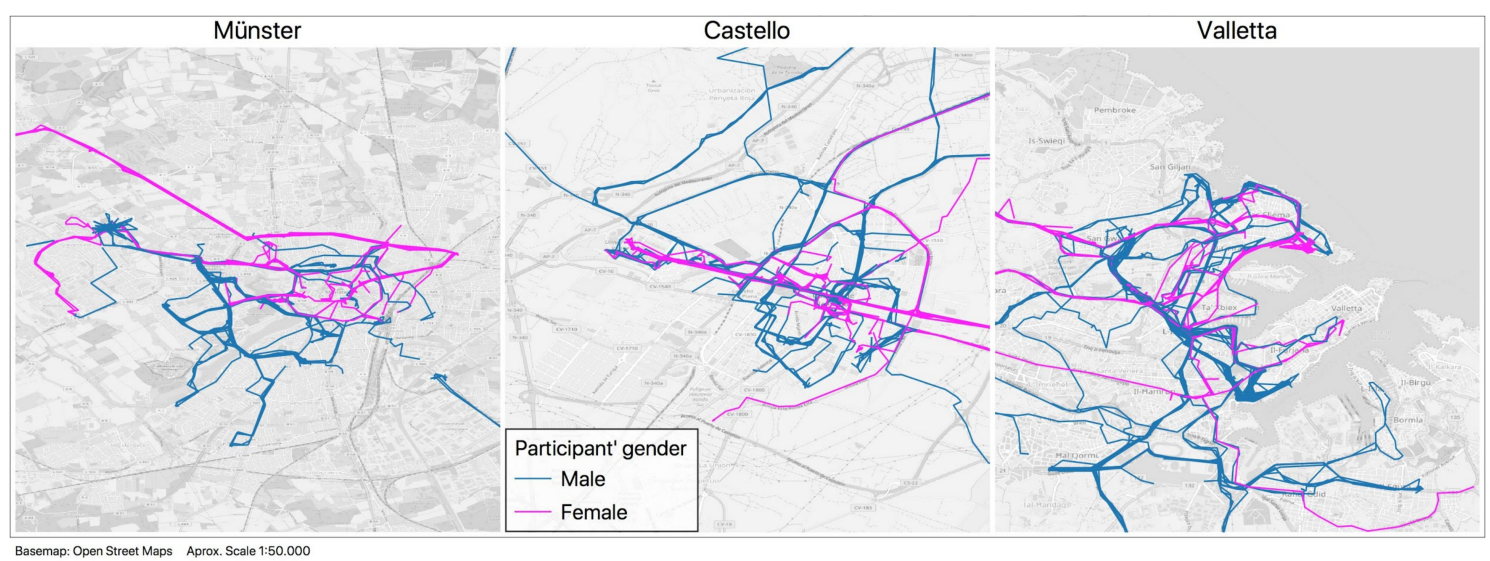

Figure 5.8: Recorded trips distribution by gender.

There were differences between participants who used and who did not use cycling applications. Figure 5.9 shows the trips recorded by participants using and not cycling applications with colours. In Münster and Castelló, participants using cycling applications usually cycled out of the city while participants not using such applications recorded trips within the city. In Valletta, we did not find such a pattern. 
This interesting insight into the behaviour of cyclists not using cycling applications would need additional research to better identify the potential differences in cycling patterns at city level.

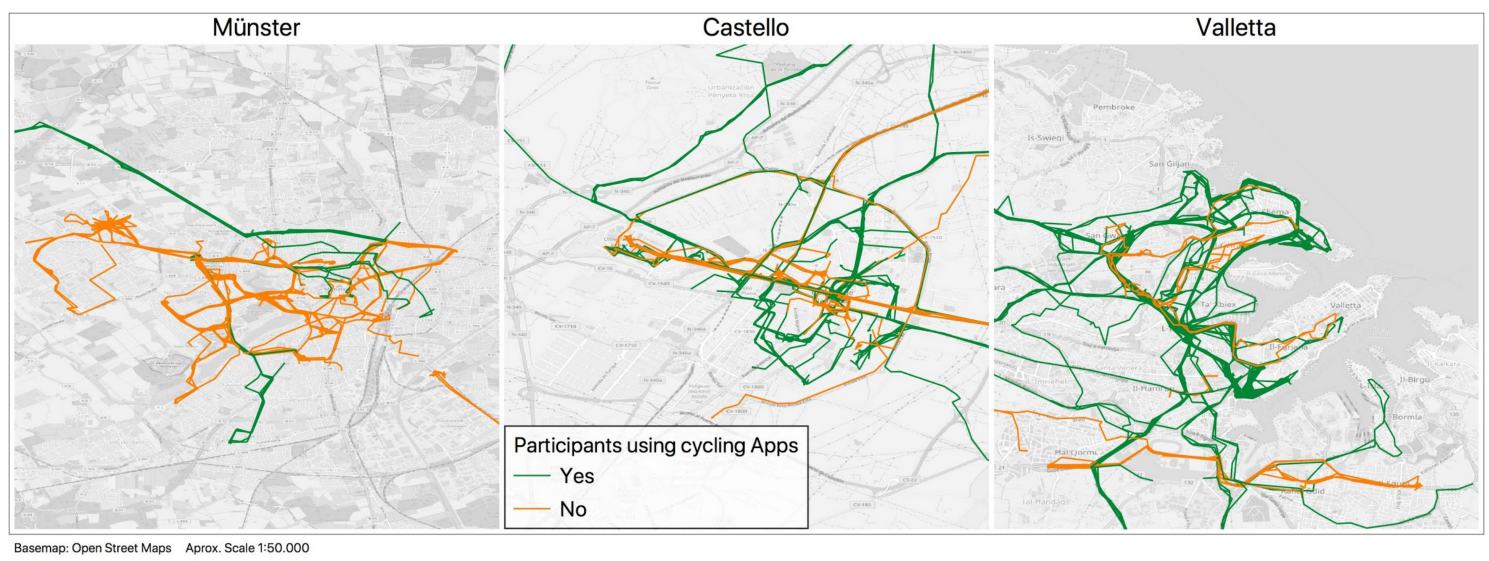

Figure 5.9: Participants' trips depending on whether or not they use cycling apps.

In addition to the traditional mapping visualisation of bicycle trips, we explored different visualisations which improved the comprehension of the patterns defined by the recorded trips. We use two geometrical simplification methods to represent trip origins, destinations, orientation angle, and distance. At the top, Figure 5.10 shows trips as a straight line connecting each trip origin and destination indicating where the trip starts or ends, and giving an idea of the distance cycled. Using this representation, we found participants from Münster usually cycling within the city boundaries, clustered in the western area with few trips connecting with a nearby town. In Castelló, participants connected with two of the surrounding east and north-east urban areas, and clustered in the connection between the university campus and the city centre. In Valletta, participants mostly cycled within the urban area but also a large number of trips connected with surrounding towns and the airport.

For the second geometrical simplification, we simulated all trips starting from a point at the city centre and following a straight line with the recorded distance and orientation. Figure 5.10 bottom shows Münster trips following the east-west direction. Castelló trips mostly followed the east-west direction and some longer trips from east-west to north-east to connect the surrounding towns. Valletta trips mostly went from north-west to south-east. We found useful this visualisation to complement the analysis of cycling patterns since it displays the main direction of 


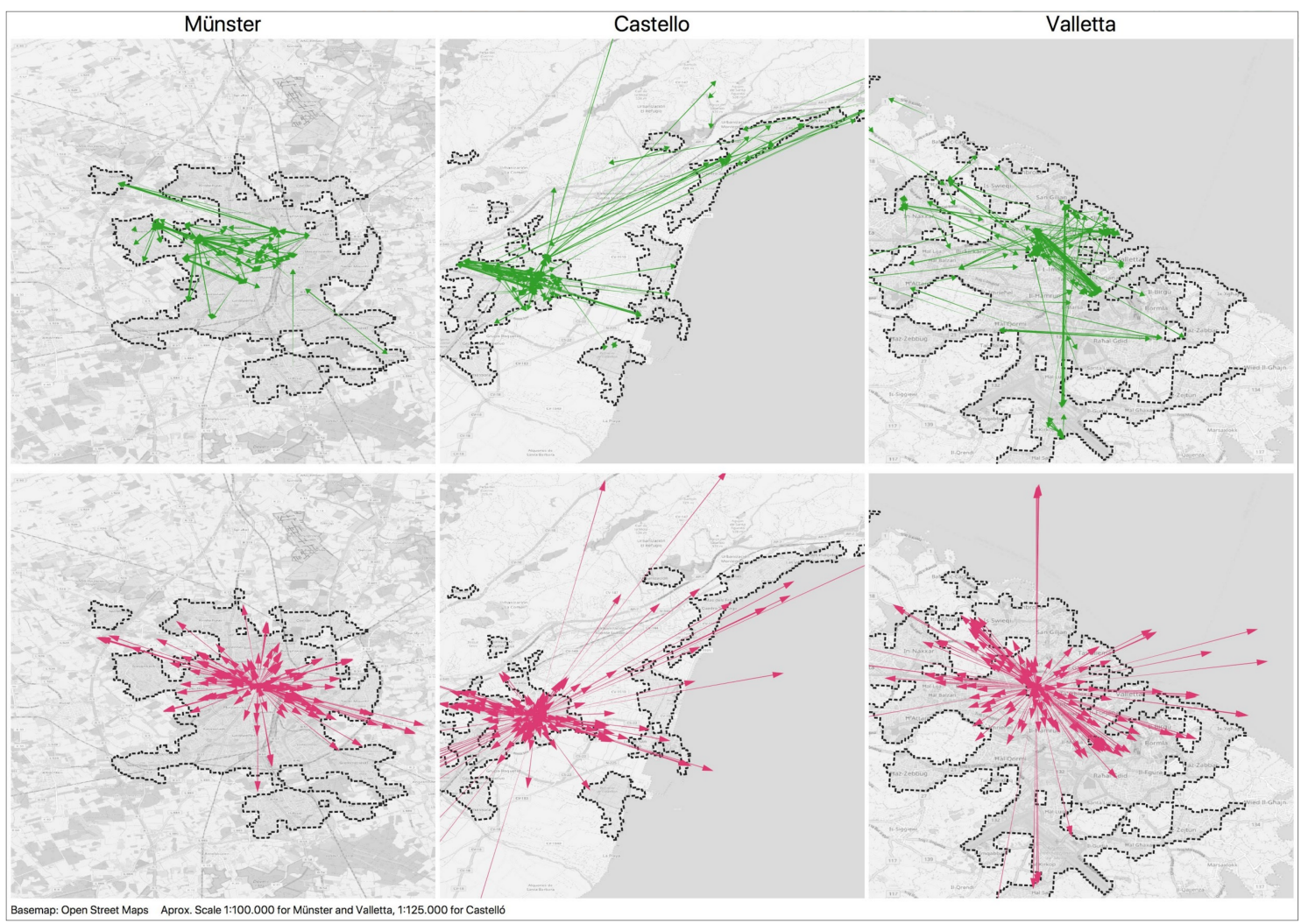

Figure 5.10: Simplified visualisation of bicycle trips.

the trips, the distance cycled, and gives an idea of the cycling commuting area.

We successfully combined participants' cycling profiles and the geospatial distribution of trips. With this enhanced analysis, we found the differences between male and female trips and the areas preferred by participants using cycling apps. We also explored additional visualisation procedures to emphasise origins, destinations, orientation and trip distance. Although we are aware of the limitations to extend our results to a city level, we indeed foresee the usefulness of combining these two data sources to better understand cycling patterns from GPS tracks.

\subsubsection{Summary}

For this thesis, we successfully recruited about 60 participants in three European cities. 57 participants finished an experiment that not only evaluated the impact of virtual rewards on enjoyment, intentions, satisfaction and engagement with cycling but also crowdsourced bicycle trips. From the 793 trips recorded, we identified 
284 places with potential frictions inhibiting bicycle commuting: 71 in Münster, Germany; 70 in Castelló, Spain; and 143 in Valletta, Malta. We selected the places technically based on the friction intensity and described them considering the distance to bicycle paths, surrounding infrastructure and location in the urban area.

The previous results fed this last discussion, divided into two sections. Firstly, from the cyclist's perspective, we showed how mobile devices help to encourage people to increase cycling, or other physical activity; presented a method of adding a geospatial context to engage more people with cycling; and described gamified tools based on collaboration engaging with urban cycling and data collection. We also listed the lessons learned from participants recording bicycle trips for this research. Secondly, from the city's point of view, we showed how geospatial analysis helped to understand cycling conditions and support policy-making. We described the differences in cycling patterns between male and female participants, between participants who use and do not use cycling applications, and explored geospatial visualisation to emphasise the spatial features of cycling.

This discussion framed our research results and suggested combining geospatial analysis with the cycling profiles of people contributing to recording bicycle trips. It brought together the individual results of our experiments and led to the final summary of research contributions, limitations and recommendations. 



\section{Chapter 6}

\section{Conclusion}

This chapter concludes the thesis and summarises the outcomes of our research, the limitations faced during the experiments, and recommendations for future work. It starts with a compilation of the research outcomes and how such outcomes contributed to answering the research questions. It continues with a description of the limitations of our research with the way we tried to overcome them. Finally, we list the recommendations and possible future works identified during our research. The recommendations are intended to be as specific as possible to motivate researchers, mobile applications developers, urban analysts and cities interested in analysing urban cycling and to make open cities possible in the future.

\subsection{Summary of the thesis outcomes}

We present the thesis outcomes associated with the three research questions following the schematic description of Figure 5.1. The first group is related to the impact of mobile services and virtual rewards on urban cycling and on green living in general. Our most significant contribution came from the evaluation of the impact of types of incentive on urban cycling, see Chapter 3 , and the finding of collaboration-based rewards serving better to increase enjoyment, intentions, satisfaction and engagement with urban cycling. These findings also reinforce the idea of using gamified tools or serious games to encourage behavioural change and, in our case, reach the urban cycling community to validate the convenience of using mobile technologies to improve the existing cycling information.

Our expertise and awareness of the capabilities of geospatial technologies 
brought us to the idea of mobile applications and gamified tools focusing on urban cyclists being effective to engage people with crowdsourcing cycling data collection. However, we foresee the difficulties in implementing and maintaining a technological platform without explicit institutional support.

The second group of research outcomes corresponds to the frictions inhibiting bicycle commuting and the location of areas constraining urban cycling. We started with the little available scientific literature on the use of information technologies to analyse urban cycling as well as the bias linking the use of such technologies only with the practice of sport. We also found most of the research available using customised prototypes and very few publications reporting the use of popular commercial cycling applications such as Strava, Endomondo, Polar or Wikiloc.

Our experimental design allowed us to crowdsource data collection in three European cities, establish direct contact with urban cyclists, an understand their perceptions of mobile technologies. The experiments also served to test a method to identify frictions inhibiting bicycle commuting using crowdsourced bicycle trips. The frictions identified were mostly related to intersections and the movements on and off bicycle paths. Both the experimental design and the geospatial analyses applied proved to be replicable and reusable in future studies while the gridbased approach served to complement existing analysis strategies, such as mapmatching and offered alternatives for analysing cycling patterns.

Our thesis results support the idea of crowdsourcing information as a useful practice to increase openness in cities. In particular, we got positive results from the interaction of cyclists with gamified tools, as well as from the identification of cycling patterns. Regarding the interaction, we found gamified tools using collaboration-based rewards useful to engage urban cyclists with crowdsourcing cycling data collection.

The third group of research outcomes corresponds to the role of geoinformation sciences in enabling the analysis of urban systems such as cycling or green living. The development and test of analysis routines contributed with new tools for urban analysts willing to comprehend mobility and design site-specific interventions. By doing so, future pro-cycling policies, such as the deployment of protected cycling facilities, providing a safer environment for women, children, seniors, or reducing the risk on roads with motor vehicles will probably be more data-driven.

We also foresee our research outcomes contributing to the development of open 
and smart cities, enhancing citizen participation and the use of mobile technologies to connect citizens and governments. Experimenting with our mobile applications brought us insights into the integration of location technologies with pro-cycling interventions, as well as the need for interacting directly with the final users of such technology.

\subsubsection{Contributions to future open and smart cities}

This research uses fundamental concepts and up-to-date tools from geoinformatics. Therefore its contributions are aligned with the contributions of geoinformatics to open and smart cities in general. In the same direction of Roche (2014) reflection, the use of location-based services for gathering city data provides a more explicit context to urban analysis on the one hand and a more accurate description of phenomena.

By crowdsourcing data collection, cities increase the quantity of data, reduce times to update datasets and resources invested in data collection. However, crowdsourcing data collection also implies an enormous refining task which might be considered before any analysis. Our research consequently found that adding a recruiting phase, to clarify the purpose of the study and the data collection procedure, should produce higher data quality. Future research in this area is needed to better estimate the benefits of such previous actions.

Beyond crowdsourcing data collection and spatial analysis of bicycle trips, involving urban cyclists in the analysis of urban challenges benefits open and smart city development. Depending on the kind of task and level of engagement of participants, such procedures might improve transparency of city administration, engagement of citizens with participatory processes and willingness to collaborate with other citizens or groups. According to the concept of open cities which drove our research (see Degbelo et al. (2016a) and Degbelo et al. (2016a)), the benefits of these city processes also impact the development of open and smart cities.

\subsubsection{Technical outcomes of the thesis}

Our research also brought outcomes more related to information technologies. Most of such outcomes are part of the Geo-C Open City toolkit. We briefly describe the technical outcomes below. 
- Datasets. These include the table which compiles participants' answers to the questionnaires and the bicycle trips mapped data. Also included is the compilation of secondary information used to describe the frictions inhibiting bicycle commuting.

- Scientific publications. The set of articles and presentations delivered during the research period which served to exchange experiences with researchers working on related topics (See Appendix A).

- Questionnaires. The different questionnaires designed which could serve as a reference for future studies on cycling.

- Mobile application. This refers to the source code of our experimental application which could be adapted or integrated into existing solutions to support crowdsourcing data collection.

- Analysis scripts. The set of routines implemented in popular languages such as $R$ and Python to build geometries and spatially analyse bicycle trips and identify frictions. These scripts could serve for the analysis of crowdsourced datasets captured using mobile devices in general.

\subsection{Limitations}

During our research, we faced various limitations which helped us to either refine the results or identify opportunities for future studies. Working with mobile phone applications, we faced the rapid obsolescence of devices and software components. We therefore needed to restrict our literature review to the years 2014-2017 to reduce experiments using non-existing or unavailable technologies. From the software development perspective, we build an Android application for the 7 and earlier versions of the OS to support a wider variety of devices. Unfortunately, we could not develop a version for iOS which forced us to discard participants using iPhone devices due to the lack of time within the Geo-C project.

Although our focus was on urban cycling, we discarded the analysis of bicyclesharing systems and electric bicycles. We generalised our scope to frictions faced by cyclists without considering bicycle ownership or propulsion technology. Additionally, due to the access limitations to data from commercial cycling applications, 
we could not compare the cycling patterns obtained from our dataset with the patterns obtained from a more significant dataset in detail.

Although we deployed the experiment in three cities and followed a betweengroups experimental design, we only obtained the participants which ensured a comparison between the groups. Therefore, our results cannot be extended to a city level and do not represent the cycling environment of the three cities.

Finally, we note two limitations of our study, the small sample size and the need for validation field work. Regarding the limited sample size, we defined a recruitment procedure which relied on a budget for compensating participants considering the tasks to perform and the profile needed. Although a bigger budget would increase the chances of recruiting more people, we also faced difficulties convincing cyclists to join the experiment, especially for their personal and professional time constraints. The task of recruiting such a particular group of participants to perform the particular series of actions constrained our opportunities to have a bigger sample size.

Regarding the validation field-work, despite our research interest in geoinformatics, we considered validation field work to be important. A more extended PhD schedule would undoubtedly have helped us to design a validation field-work procedure.

\subsection{Recommendations and future work}

From our research outcomes, we identified some future research opportunities and specific recommendations for researchers, application developers, and urban analysts. We grouped these recommendations into three main categories: further development of gamification and serious games, the user experience related to information technologies for cyclists, and data analysis tasks.

For the first group, we foresee an enormous potential in gamified tools and the development of serious games to encourage behavioural changes towards green living. Primarily, we consider collaboration-based incentives a good way of improving the interaction between citizens and urban systems. Designing tasks and more elaborate "game mechanics" rather than technological development could play a more central role, as our participants seemed more interested in contributing and interacting with other cyclists than testing and playing with application features. 
For the second group, urban cycling is changing dramatically, and the adoption of bicycle-sharing systems modified the relationship with bicycles as it has removed barriers to owning and maintaining them. The role of these systems would therefore need to be taken into account in motivating urban cyclists.

For the third group, the research on urban cycling must maintain a user-centred approach despite the new devices and technologies involved. Due to the link with location data and the greater awareness of users' privacy feeding into the research, we foresee challenges in collectively generating cycling data without invading or exposing private information. 
The National Academy of Sciences cited GPS as an example of how basic research leads to practical technologies that were "virtually unimaginable at the time the research was done"

The Mapmakers, John Noble Wilford 



\section{Appendix A}

\section{Publications}

- Journal papers:

1. Diego Pajarito, Michael Gould. Mapping frictions inhibiting bicycle commuting. In: International Journal of Geo-information. Volume 7, Issue 10. 2008. Doi: 10.3390/ijgi7100396. https://www.mdpi.com/ $2220-9964 / 7 / 10 / 396$

2. Diego Pajarito, Auriol Degbelo, Michael Gould. Collaboration or Competition: the Impact of Incentive Types on Urban Cycling. Submitted for publication. International Journal of Sustainable Transportation.

- Conference papers:

1. Diego Pajarito, Suzanne Maas, Maria Attard, Michael Gould. Mapping cyclists' routes: involving citizens in collecting open cycling data. In: 21th AGILE Conference on Geographic Information Science. ISSN 978-3-319-78208-9. https://agile-online.org.

2. Diego Pajarito, Michael Gould. Smart Mobility, the Role of Mobile Games. In: International Joint Conference on Serious Games (JCSG 2017). Lecture Notes in Computer Science. ISSN 1863-2246. DOI 10.1007/978-3-319-70111-0_5. 
- Research stays:

1. The Institute for Geoinformatics. University of Münster. Supervisor Prof. Dr. Christian Kray. From February 22 to September 22, 2017.

2. The Institute for Climate Change and Sustainable Development. University of Malta. Supervisor Prof. Dr. Maria Attard. From November 9 to 18, 2017. 


\section{Appendix B}

\section{Pre and Post Questionnaires}

The following are the pre and post questionnaires used during the experiment. They were translated into English, Catalan and European Spanish. Questionnaires are ordered as follows:

- Questionnaire 1: Page 1 and 2.

- Questionnaire 2: Collaboration condition and competition condition 


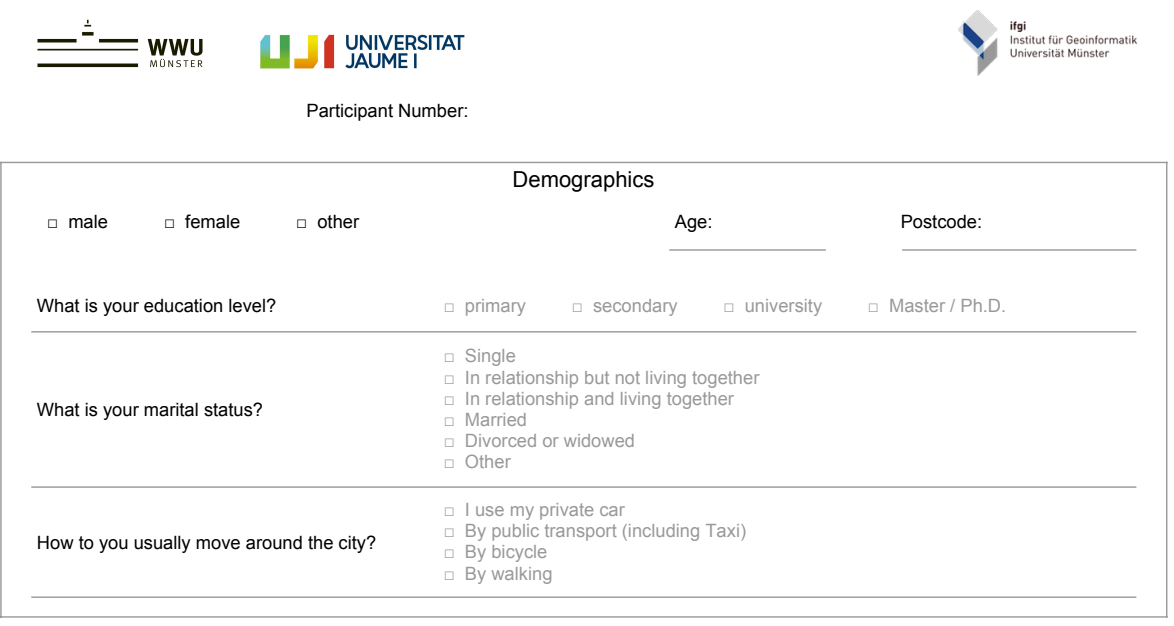

\begin{tabular}{|c|c|c|c|}
\hline \multicolumn{4}{|c|}{ Cycling } \\
\hline \multicolumn{4}{|c|}{$\begin{array}{c}\text { Consider the following scenario, read each of the statements below and then indicate to which extent you agree or } \\
\text { disagree with them: }\end{array}$} \\
\hline \multicolumn{4}{|c|}{ Scenario: "If I make, or were to make, journeys by bicycle:" } \\
\hline I would find cycling enjoyable & Strongly disagree & ロ & Strongly agree \\
\hline I would get a sense of freedom & Strongly disagree & 口 & Strongly agree \\
\hline I would feel part of my community & Strongly disagree & 口 & Strongly agree \\
\hline I would find it relaxing & Strongly disagree & 口 & Strongly agree \\
\hline More cycle lanes would make me feel safer & Strongly disagree & 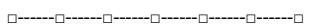 & Strongly agree \\
\hline It would benefit my health & Strongly disagree & ロ & Strongly agree \\
\hline It would save me money & Strongly disagree & ロ & Strongly agree \\
\hline $\begin{array}{l}\text { It would be a bad experience using the } \\
\text { existing roads }\end{array}$ & Strongly disagree & 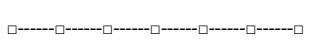 & Strongly agree \\
\hline $\begin{array}{l}\text { It would mean "I contribute less to climate } \\
\text { change" }\end{array}$ & Strongly disagree & 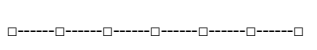 & Strongly agree \\
\hline It would be too much physical effort & Strongly disagree & 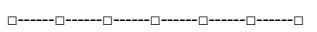 & Strongly agree \\
\hline $\begin{array}{l}\text { It would more than likely expose me to wet } \\
\text { or windy weather }\end{array}$ & Strongly disagree & 口 & Strongly agree \\
\hline $\begin{array}{l}\text { It would mean "I contribute less to local air } \\
\text { pollution" }\end{array}$ & Strongly disagree & 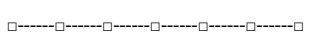 & Strongly agree \\
\hline It would take me too long & Strongly disagree & 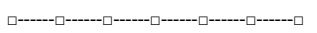 & Strongly agree \\
\hline $\begin{array}{l}\text { It would put my bike at risk of being stolen } \\
\text { whilst parked }\end{array}$ & Strongly disagree & 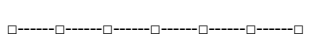 & Strongly agree \\
\hline $\begin{array}{l}\text { It would mean I have to negotiate difficult } \\
\text { road junctions }\end{array}$ & Strongly disagree & 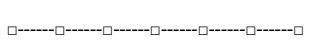 & Strongly agree \\
\hline
\end{tabular}




\begin{tabular}{|c|c|c|c|}
\hline \multicolumn{4}{|c|}{ Participant Number: } \\
\hline \multicolumn{4}{|c|}{ Mobile Phone Use } \\
\hline $\begin{array}{l}\text { How long do you use your phone during the } \\
\text { day? }\end{array}$ & \multicolumn{2}{|c|}{$\begin{array}{l}\text { Less than } 30 \mathrm{~min} \\
\text { Between } 30 \mathrm{~min} \text { and } 1 \text { hour } \\
\text { Between } 1 \text { and } 2 \text { hours } \\
\text { Between } 2 \text { and } 5 \text { hours } \\
\square \text { More than } 5 \text { hours }\end{array}$} & \\
\hline $\begin{array}{l}\text { How much money do you spend on } \\
\text { applications for your mobile phone during } \\
\text { the month? }\end{array}$ & \multicolumn{3}{|c|}{$\begin{array}{l}\square \text { I don't spend money on that } \\
\square \text { Less than } 10 \text { EUR } \\
\text { Between } 10 \text { and } 25 \text { EUR } \\
\text { More than } 25 \text { EUR }\end{array}$} \\
\hline $\begin{array}{l}\text { What kind of applications do you usually } \\
\text { use on your phone? (Multiple choise) }\end{array}$ & \multicolumn{3}{|c|}{$\begin{array}{l}\text { Basic Utility (i.e. Calculator, Weather, Reminder, etc.) } \\
\text { Messaging and Social Networks } \\
\text { Lifestyle and Fitness (i.e. Excercise, Travel, Music, Food, Dating, etc.) } \\
\text { Games and Entertainment } \\
\text { Productivity (i.e. Documents, Sheets, Pay, Checklist, etc.) } \\
\square \text { News and Information }\end{array}$} \\
\hline $\begin{array}{l}\text { How much time do you spend playing with } \\
\text { your phone during the day? }\end{array}$ & \multicolumn{3}{|c|}{$\begin{array}{l}\text { Less than } 30 \mathrm{~min} \\
\text { Between } 30 \mathrm{~min} \text { and } 1 \text { hour } \\
\text { Between } 1 \text { and } 2 \text { hours } \\
\text { Between } 2 \text { and } 5 \text { hours } \\
\text { More than } 5 \text { hours }\end{array}$} \\
\hline $\begin{array}{l}\text { How much money do you spend on games } \\
\text { for your mobile phone during the month? }\end{array}$ & \multicolumn{3}{|c|}{$\begin{array}{l}\square \text { I don't spend money on that } \\
\square \text { Less than } 10 \text { EUR } \\
\text { Between } 10 \text { and } 25 \text { EUR } \\
\square \text { More than } 25 \text { EUR }\end{array}$} \\
\hline $\begin{array}{l}\text { What kind of games do you usually play on } \\
\text { your phone? (Multiple choice) }\end{array}$ & $\begin{array}{l}\square \text { Simulation } \\
\square \text { Puzzle } \\
\square \text { Action } \\
\square \text { Stealth Shooter } \\
\square \text { Combat } \\
\square \text { None }\end{array}$ & \multicolumn{2}{|l|}{$\begin{array}{l}\square \text { First Person Shooting } \\
\square \text { Sports } \\
\square \text { Role-Playing } \\
\square \text { Educational } \\
\square \text { Other }\end{array}$} \\
\hline $\begin{array}{l}\text { Do you use any application when you are } \\
\text { cycling? }\end{array}$ & $\square$ No & \multicolumn{2}{|l|}{$\square$ Yes } \\
\hline $\begin{array}{l}\text { If YES (I use an application when I am } \\
\text { cycling), which of the following is/are? } \\
\text { (Multiple choice) }\end{array}$ & $\begin{array}{l}\square \text { Google Fit } \\
\square \text { Endomondo } \\
\square \text { Bike Citizens } \\
\square \text { Fitbit } \\
\square \text { None }\end{array}$ & \multicolumn{2}{|l|}{$\begin{array}{l}\square \text { Strava } \\
\square \text { Runtastic } \\
\square \text { Human } \\
\square \text { Wikiloc } \\
\square \text { Other }\end{array}$} \\
\hline $\begin{array}{l}\text { Which of the following social apps do you } \\
\text { usually use? (Multiple choice) }\end{array}$ & $\begin{array}{l}\square \text { Foursquare } \\
\square \text { Trip Advisor } \\
\square \text { Find my friends } \\
\square \text { Tinder } \\
\square \text { None }\end{array}$ & $\begin{array}{l}\square \text { Swarm } \\
\square \text { Snapchat map } \\
\square \text { Waze } \\
\square \text { Other }\end{array}$ & \\
\hline $\begin{array}{l}\text { Which of the following wearable devices do } \\
\text { you usually use? (Multiple choice) }\end{array}$ & $\begin{array}{l}\square \text { Fitness band } \\
\text { VR headset } \\
\square \text { Smart glasses } \\
\square \text { none }\end{array}$ & $\begin{array}{l}\square \text { Smart watch } \\
\text { Smart headphones } \\
\square \text { Other }\end{array}$ & \\
\hline 'My intention to use a bicycle is' & Very weak & 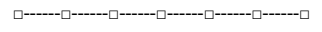 & Very strong \\
\hline $\begin{array}{l}\text { 'My intention to play some game on my } \\
\text { phone is' }\end{array}$ & Very weak & 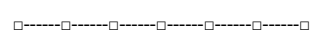 & Very strong \\
\hline 'My intention to use an app while cycling is' & Very weak & ロ & Very strong \\
\hline
\end{tabular}




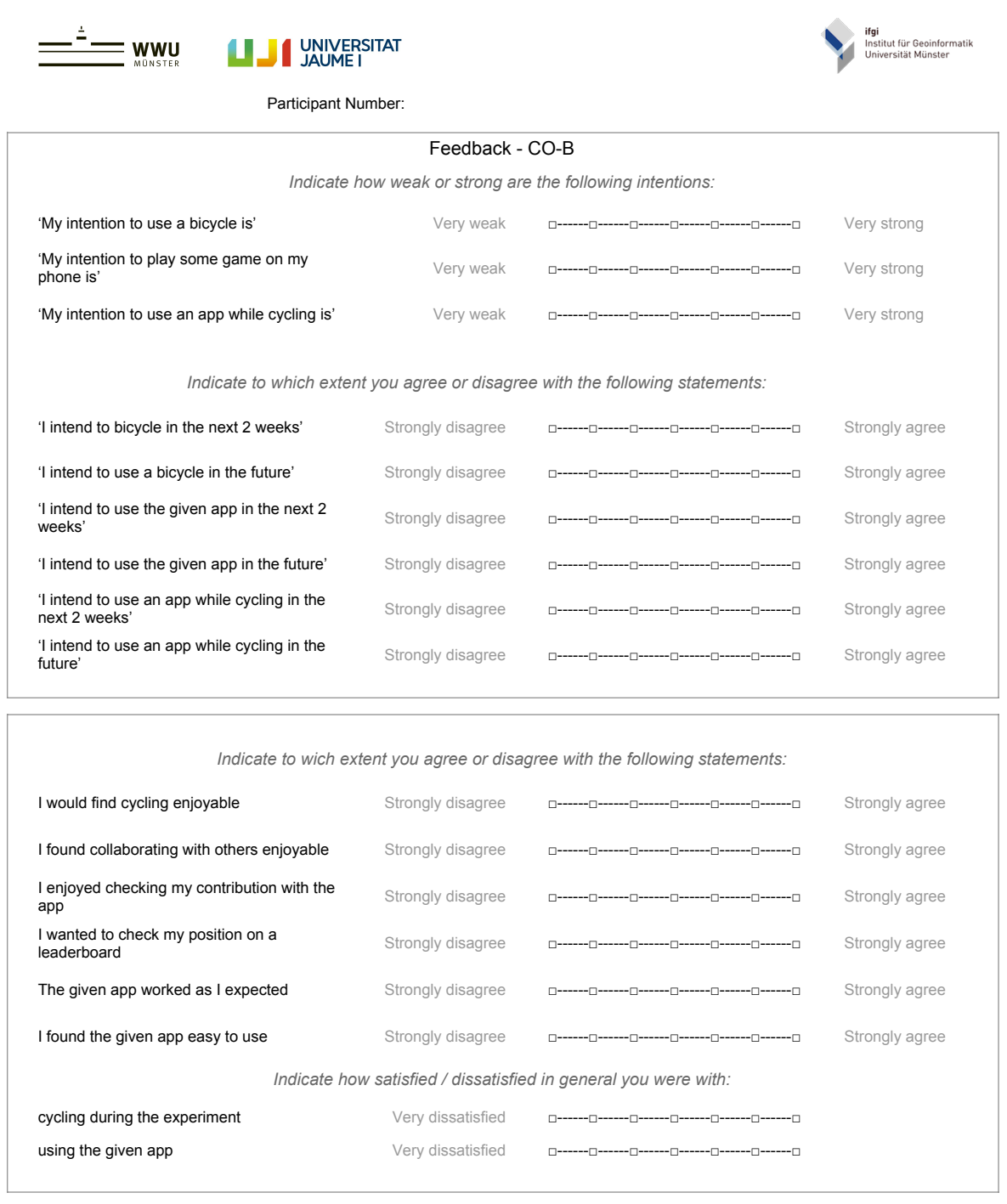

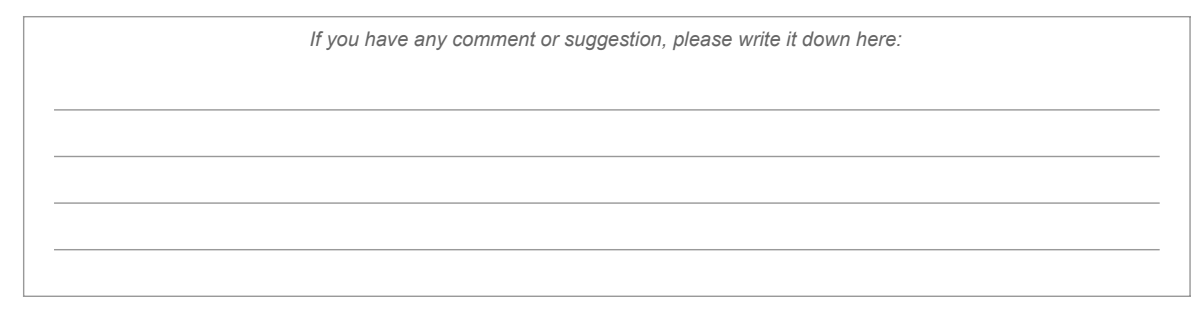




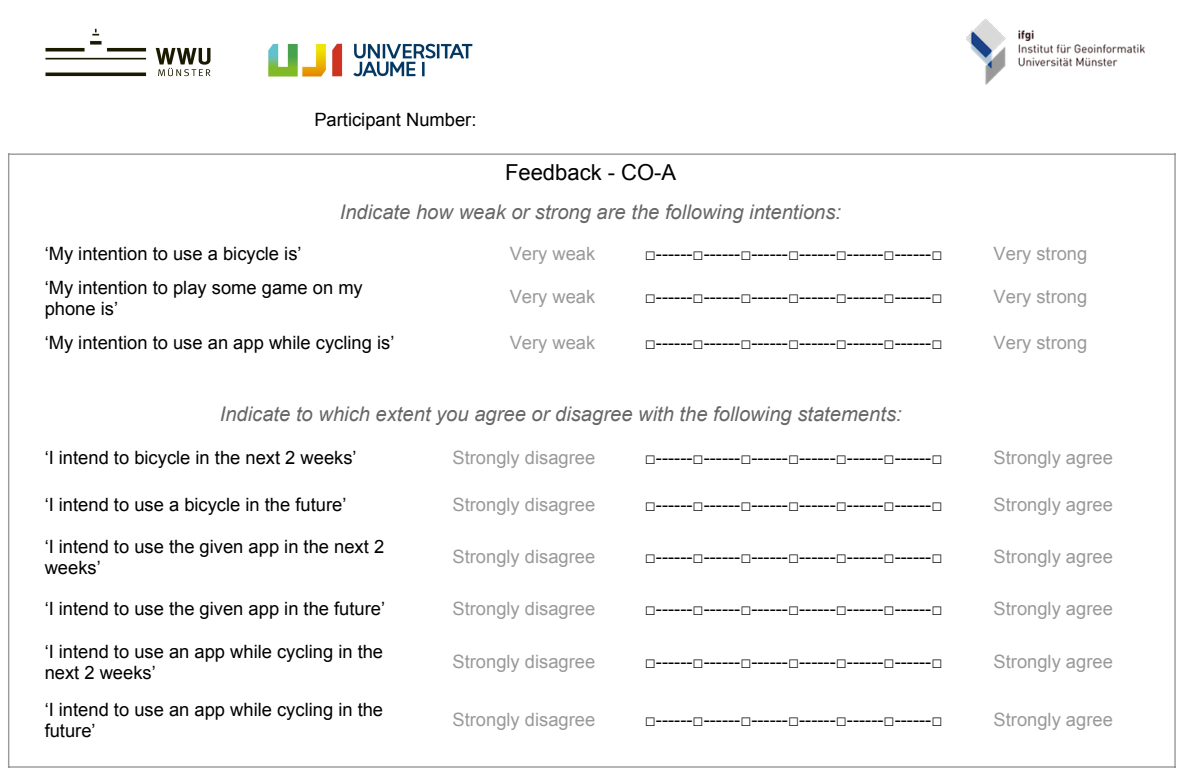

\begin{tabular}{|c|c|c|c|}
\hline \multicolumn{4}{|c|}{ Indicate to wich extent you agree or disagree with the following statements: } \\
\hline I found cycling enjoyable & Strongly disagree & 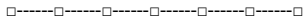 & Strongly agree \\
\hline $\begin{array}{l}\text { I found competing against other cyclists } \\
\text { enjoyable }\end{array}$ & Strongly disagree & 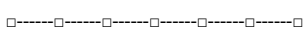 & Strongly agree \\
\hline $\begin{array}{l}\text { I enjoyed checking my own progress with } \\
\text { the app }\end{array}$ & Strongly disagree & 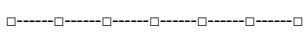 & Strongly agree \\
\hline $\begin{array}{l}\text { I enjoyed checking my position on the } \\
\text { leaderboard }\end{array}$ & Strongly disagree & 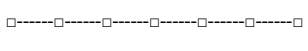 & Strongly agree \\
\hline The given app worked as I expected & Strongly disagree & 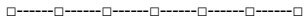 & Strongly agree \\
\hline I found the given app easy to use & Strongly disagree & 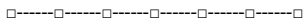 & Strongly agree \\
\hline \multicolumn{4}{|c|}{ Indicate how satisfied / dissatisfied in general you were with: } \\
\hline cycling during the experiment & Very dissatisfied & 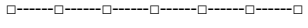 & Very satisfied \\
\hline using the given app & Very dissatisfied & 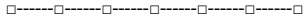 & Very satisfied \\
\hline
\end{tabular}

\begin{tabular}{|l|}
\hline If you have any comment or suggestion, please write it down here: \\
\hline \\
\hline
\end{tabular}




\section{UNIVERSITAT}

Geচ-С

\begin{tabular}{|c|c|c|c|c|c|}
\hline \multicolumn{6}{|c|}{ Demografia } \\
\hline$\square$ masculí & $\square$ femení & & $\mathrm{Ec}$ & & Còdig Postal: \\
\hline \multicolumn{2}{|c|}{ Quin és el teu nivell educatiu? } & $\square$ primària & $\square$ secundària & $\square$ universitària & $\square$ Master / Doctorat \\
\hline \multicolumn{2}{|c|}{ Quin es el teu estat civil? } & $\begin{array}{l}\square \text { Solter } \\
\square \text { En una re } \\
\square \text { En una re } \\
\square \text { Casat } \\
\square \text { Divorciat } \\
\square \text { Altre }\end{array}$ & $\begin{array}{l}\text { ció però sense v } \\
\text { ció visquem junt } \\
\text { idu }\end{array}$ & junts & \\
\hline \multicolumn{2}{|c|}{ Com et mous usualment per la ciutat? } & $\begin{array}{l}\square \text { Uso el me } \\
\square \text { En transp } \\
\square \text { En bicicle } \\
\square \text { Caminant }\end{array}$ & $\begin{array}{l}\text { cotxe } \\
\text { públic (Incluit T }\end{array}$ & & \\
\hline
\end{tabular}

\begin{tabular}{|c|c|c|c|}
\hline \multicolumn{4}{|c|}{ Anar amb bici } \\
\hline \multicolumn{4}{|c|}{$\begin{array}{c}\text { Considerant el següent escenari, llig les frases i després indica en quina mesura estàs d'acord o en desacord amb } \\
\text { cadascuna d'elles }\end{array}$} \\
\hline \multicolumn{4}{|c|}{ Escenari: "Si vaig amb bicicleta" } \\
\hline M'agrada anar amb bicicleta & Totalmente en desacord & 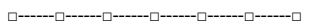 & Totalment d'acord \\
\hline Em produeix una sensació de llibertat & Totalmente en desacord & 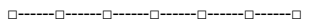 & Totalment d'acord \\
\hline Em fa sentir part de la meua comunitat & Totalmente en desacord & 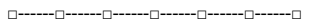 & Totalment d'acord \\
\hline Em relaxa & Totalmente en desacord & 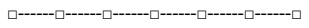 & Totalment d'acord \\
\hline $\begin{array}{l}\text { Disposar de més carrils per a bicicletes em } \\
\text { farien sentir més segur }\end{array}$ & Totalmente en desacord & 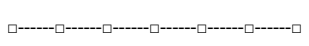 & Totalment d'acord \\
\hline Beneficia la meua salut & Totalmente en desacord & 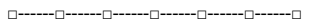 & Totalment d'acord \\
\hline Estalvie diners & Totalmente en desacord & 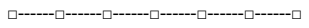 & Totalment d'acord \\
\hline $\begin{array}{l}\text { És una mala experiència fent servir les vies } \\
\text { actuals }\end{array}$ & Totalmente en desacord & 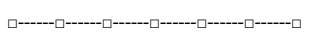 & Totalment d'acord \\
\hline Contribuisc menys al canvi climàtic & Totalmente en desacord & 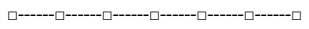 & Totalment d'acord \\
\hline És un grán esforç físic & Totalmente en desacord & 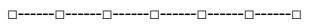 & Totalment d'acord \\
\hline Estic més exposat al vent i la humitat & Totalmente en desacord & 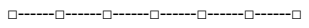 & Totalment d'acord \\
\hline Contamine menys l'aire & Totalmente en desacord & 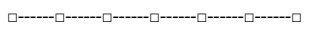 & Totalment d'acord \\
\hline Em pren molt més temps & Totalmente en desacord & ם & Totalment d'acord \\
\hline $\begin{array}{l}\text { Posaria la meua bicicleta en risc de ser } \\
\text { robada mentre està aparcada }\end{array}$ & Totalmente en desacord & 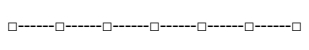 & Totalment d'acord \\
\hline $\begin{array}{l}\text { Tinc dubtes sobre com procedir en } \\
\text { interseccions difícils }\end{array}$ & Totalmente en desacord & 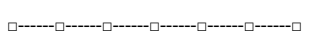 & Totalment d'acord \\
\hline
\end{tabular}




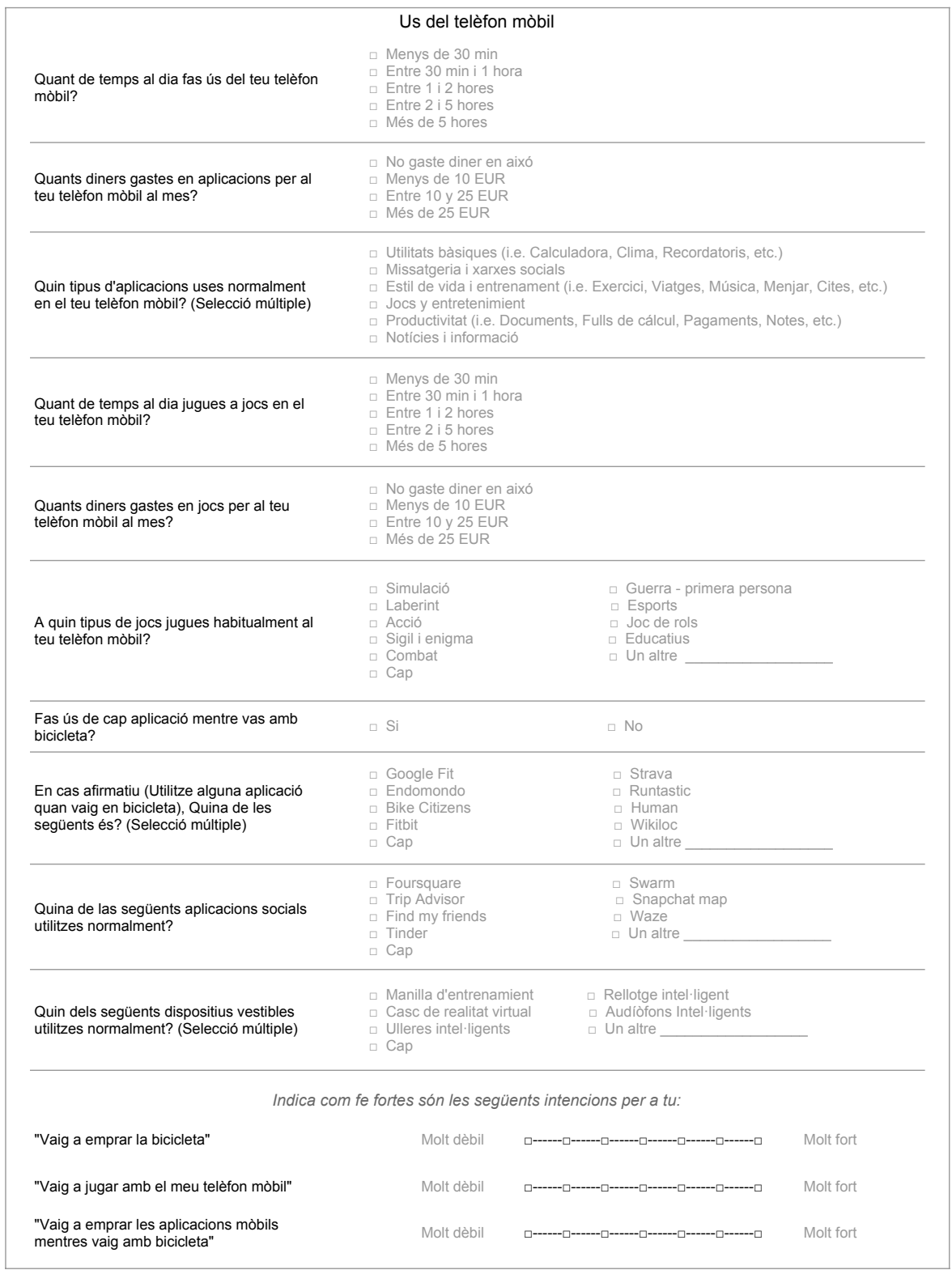




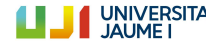

Geo.c

\begin{tabular}{|c|c|c|c|}
\hline \multicolumn{4}{|c|}{ Retroalimentació - CO-B } \\
\hline \multicolumn{4}{|c|}{ Indica com fe fortes són les següents intencions per a tu: } \\
\hline "Vaig a emprar la bicicleta" & Molt dèbil & 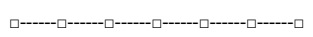 & Molt fort \\
\hline "Vaig a jugar amb el meu telèfon mòbil" & Molt dèbil & 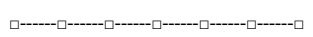 & Molt fort \\
\hline $\begin{array}{l}\text { "Vaig a emprar les aplicacions mòbils } \\
\text { mentres vaig amb bicicleta" }\end{array}$ & Molt dèbil & 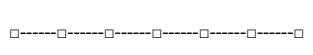 & Molt fort \\
\hline \multicolumn{4}{|c|}{ Indica en quina mesua estàs d'acord o en desacord amb les següents frases: } \\
\hline $\begin{array}{l}\text { "Aniré amb bicicleta en les pròximes } 2 \\
\text { setmanes" }\end{array}$ & Totalmente en desacord & 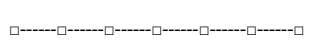 & Totalment d'acord \\
\hline "Aniré amb bicicleta en el futur" & Totalmente en desacord & 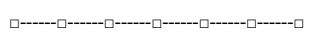 & Totalment d'acord \\
\hline $\begin{array}{l}\text { "Utilitzaré l'aplicacio mòbil de l'experiment } \\
\text { en les proximes } 2 \text { setmanes" }\end{array}$ & Totalmente en desacord & 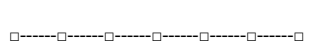 & Totalment d'acord \\
\hline $\begin{array}{l}\text { "Utilitzaré l'aplicacio mòbil de l'experiment } \\
\text { en el futur" }\end{array}$ & Totalmente en desacord & 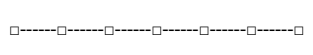 & Totalment d'acord \\
\hline $\begin{array}{l}\text { "Utilitzare una aplicació mòbil mentre vaig } \\
\text { amb bicicleta en les próximes } 2 \text { semanes" }\end{array}$ & Totalmente en desacord & 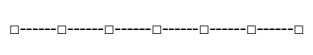 & Totalment d'acord \\
\hline $\begin{array}{l}\text { "Utilitzaré una aplicació mòbil mentre vaig } \\
\text { amb bicicleta en el futur" }\end{array}$ & Totalmente en desacord & 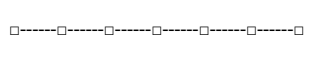 & Totalment d'acord \\
\hline \multicolumn{4}{|c|}{ Indica en quina mesura estàs d'acord o en desacord amb les següentes frases: } \\
\hline Gaudisc anant amb bicicleta & Strongly disagree & ם & Strongly agree \\
\hline Gaudisc col-laborant amb altres ciclistes & Strongly disagree & ם & Strongly agree \\
\hline $\begin{array}{l}\text { Gaudisc veient la meua contribució a } \\
\text { l'aplicació }\end{array}$ & Strongly disagree & 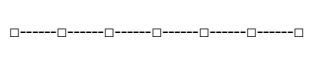 & Strongly agree \\
\hline $\begin{array}{l}\text { Voldria veure la meua posició en la taula de } \\
\text { líders }\end{array}$ & Strongly disagree & 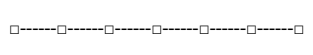 & Strongly agree \\
\hline $\begin{array}{l}\text { L'aplicació de l'experiment va funcionar } \\
\text { com esperava }\end{array}$ & Strongly disagree & 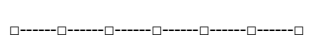 & Strongly agree \\
\hline $\begin{array}{l}\text { Crec que l'aplicació de l'experiment és fàcil } \\
\text { d'utilitzar }\end{array}$ & Strongly disagree & 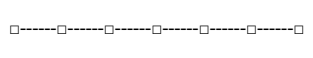 & Strongly agree \\
\hline \multicolumn{4}{|c|}{ Indica el nivel de satisfacción / insatisfacción general que tuviste al: } \\
\hline Ir en bicicleta durante el experimento & Muy insatisfet & ם & Molt satisfet \\
\hline Usar la aplicación del experimento & Muy insatisfet & 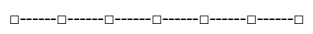 & Molt satisfet \\
\hline
\end{tabular}

\begin{tabular}{l}
\hline Si tens cap comentari o suggeriment, per favor escriu-lo a continuació: \\
\hline \\
\hline \\
\hline
\end{tabular}




\section{HI UNIVESITAT}

Geロ-ᄃ

\begin{tabular}{|c|c|c|c|}
\hline \multicolumn{4}{|c|}{ Retroalimentació - CO-A } \\
\hline \multicolumn{4}{|c|}{ Indica com fe fortes són les següents intencions per a tu: } \\
\hline "Vaig a emprar la bicicleta" & Very weak & 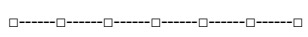 & Very strong \\
\hline "Vaig a jugar amb el meu telèfon mòbil" & Very weak & 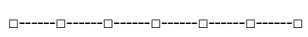 & Very strong \\
\hline $\begin{array}{l}\text { "Vaig a emprar les aplicacions mòbils } \\
\text { mentres vaig amb bicicleta" }\end{array}$ & Very weak & 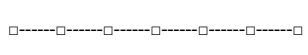 & Very strong \\
\hline \multicolumn{4}{|c|}{ Indica en quina mesua estàs d'acord o en desacord amb les següents frases: } \\
\hline $\begin{array}{l}\text { "Aniré amb bicicleta en les pròximes } 2 \\
\text { setmanes" }\end{array}$ & Totalmente en desacord & 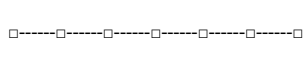 & Totalment d'acord \\
\hline "Aniré amb bicicleta en el futur" & Totalmente en desacord & ם & Totalment d'acord \\
\hline $\begin{array}{l}\text { "Utilitzaré l'aplicacio mòbil de l'experiment } \\
\text { en les proximes } 2 \text { setmanes" }\end{array}$ & Totalmente en desacord & ם & Totalment d'acord \\
\hline $\begin{array}{l}\text { "Utilitzaré l'aplicacio mòbil de l'experiment } \\
\text { en el futur" }\end{array}$ & Totalmente en desacord & 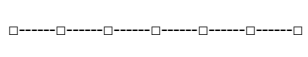 & Totalment d'acord \\
\hline $\begin{array}{l}\text { "Utilitzare una aplicació mòbil mentre vaig } \\
\text { amb bicicleta en les próximes } 2 \text { semanes" }\end{array}$ & Totalmente en desacord & 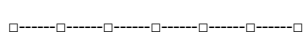 & Totalment d'acord \\
\hline $\begin{array}{l}\text { "Utilitzaré una aplicació mòbil mentre vaig } \\
\text { amb bicicleta en el futur" }\end{array}$ & Totalmente en desacord & 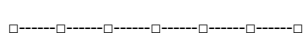 & Totalment d'acord \\
\hline
\end{tabular}

Indica en quina mesura estàs d'acord o en desacord amb les següentes frases:

\begin{tabular}{|c|c|c|c|}
\hline Gaudisc anant amb bicicleta & Totalmente en desacord & 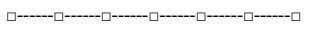 & Totalment d'acord \\
\hline Gaudisc competint amb altres ciclistes & Totalmente en desacord & 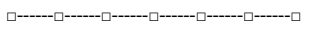 & Totalment d'acord \\
\hline Gaudisc veient el meu progrés a l'aplicació & Totalmente en desacord & ם & Totalment d'acord \\
\hline $\begin{array}{l}\text { Gaudisc veient la meua posició en el taula } \\
\text { de líders }\end{array}$ & Totalmente en desacord & - & Totalment d'acord \\
\hline $\begin{array}{l}\text { L'aplicació de l'experiment va funcionar } \\
\text { com esperava }\end{array}$ & Totalmente en desacord & 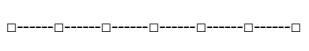 & Totalment d'acord \\
\hline $\begin{array}{l}\text { Crec que l'aplicació de l'experiment és fàcil } \\
\text { d'utilitzar }\end{array}$ & Totalmente en desacord & -..- & Totalment d'acord \\
\hline
\end{tabular}

Crec que l'aplicació de l'experiment és fàcil Totalmente en desacord

Indica el nivell de satisfacció / insatisfacció general que vas experimentar al:

Anar amb bicicleta durant l'experiment

Utilitzar l'aplicació de l'experiment

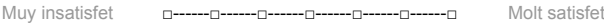

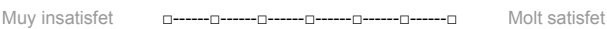

Si tens cap comentari o suggeriment, per favor escriu-lo a continuació: 
IIJ UNIVERSITAT

Geo-c

\begin{tabular}{|c|c|c|c|c|c|}
\hline \multicolumn{6}{|c|}{ Demografia } \\
\hline$\square$ masculino & $\square$ otro & \multirow{2}{*}{\multicolumn{2}{|c|}{$\square$ secundaria }} & & \multirow{2}{*}{$\begin{array}{l}\text { Código Postal: } \\
\square \text { Master / Doctorado }\end{array}$} \\
\hline ¿Cuál es tu nivel educativo? & & & & $\square$ universitaria & \\
\hline ¿Cuál es tu estado civil? & & \multicolumn{3}{|c|}{$\begin{array}{l}\square \text { Soltero } \\
\square \text { En una relación pero sin vivir juntos } \\
\square \text { En una relación viviendo juntos } \\
\square \text { Casado } \\
\square \text { Divorciado o Viudo } \\
\square \text { Otro }\end{array}$} & \\
\hline $\begin{array}{l}\text { ¿Cómo te mueves usualmente por la } \\
\text { ciudad? }\end{array}$ & & \multicolumn{3}{|c|}{$\begin{array}{l}\square \text { Uso mi auto privado } \\
\square \text { En transporte público (Incluso Taxi) } \\
\square \text { En bicicleta } \\
\square \text { Caminando }\end{array}$} & \\
\hline
\end{tabular}

\begin{tabular}{|c|c|c|c|}
\hline \multicolumn{4}{|c|}{ Uso de la bicicleta } \\
\hline \multicolumn{4}{|c|}{$\begin{array}{c}\text { Considerando el siguiente escenario, lee las frases y luego indica en qué medida estás de acuerdo o en desacuerdo con } \\
\text { cada una de ellas }\end{array}$} \\
\hline \multicolumn{4}{|c|}{ Escenario: "Cuando voy en biblicleta" } \\
\hline Me gusta ir en bicicleta & Totalmente en desacuerdo & 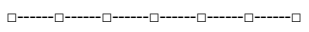 & Totalmente de acuerdo \\
\hline Me produce una sensación de libertad & Totalmente en desacuerdo & 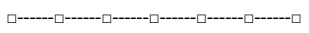 & Totalmente de acuerdo \\
\hline Me hace sentir parte de mi comunidad & Totalmente en desacuerdo & 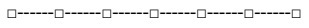 & Totalmente de acuerdo \\
\hline Me relaja & Totalmente en desacuerdo & 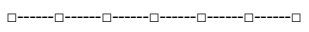 & Totalmente de acuerdo \\
\hline $\begin{array}{l}\text { Me sentiría mas seguro con más carriles } \\
\text { para bicicletas }\end{array}$ & Totalmente en desacuerdo & 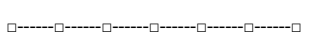 & Totalmente de acuerdo \\
\hline Beneficia mi salud & Totalmente en desacuerdo & 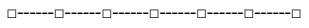 & Totalmente de acuerdo \\
\hline Ahorro dinero & Totalmente en desacuerdo & 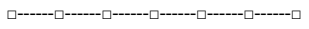 & Totalmente de acuerdo \\
\hline $\begin{array}{l}\text { Usando las vías actuales es una mala } \\
\text { experiencia }\end{array}$ & Totalmente en desacuerdo & 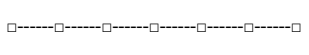 & Totalmente de acuerdo \\
\hline Contribuyo menos al cambio climático & Totalmente en desacuerdo & 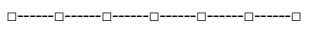 & Totalmente de acuerdo \\
\hline Me supone un gran esfuerzo físico & Totalmente en desacuerdo & 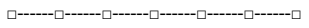 & Totalmente de acuerdo \\
\hline Estoy más expuesto al viento y la lluvia & Totalmente en desacuerdo & 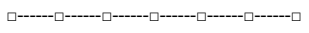 & Totalmente de acuerdo \\
\hline Contamino menos el aire & Totalmente en desacuerdo & 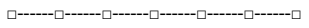 & Totalmente de acuerdo \\
\hline Me lleva mucho más tiempo & Totalmente en desacuerdo & 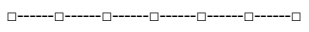 & Totalmente de acuerdo \\
\hline $\begin{array}{l}\text { Pondría mi bicicleta en riesgo de ser } \\
\text { robada mientras está aparcada }\end{array}$ & Totalmente en desacuerdo & 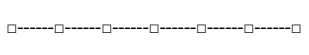 & Totalmente de acuerdo \\
\hline $\begin{array}{l}\text { Tengo dudas sobre cómo proceder en } \\
\text { intersecciones difíciles }\end{array}$ & Totalmente en desacuerdo & 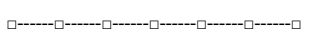 & Totalmente de acuerdo \\
\hline
\end{tabular}


11. U UNIVERSITAT

Geo-c

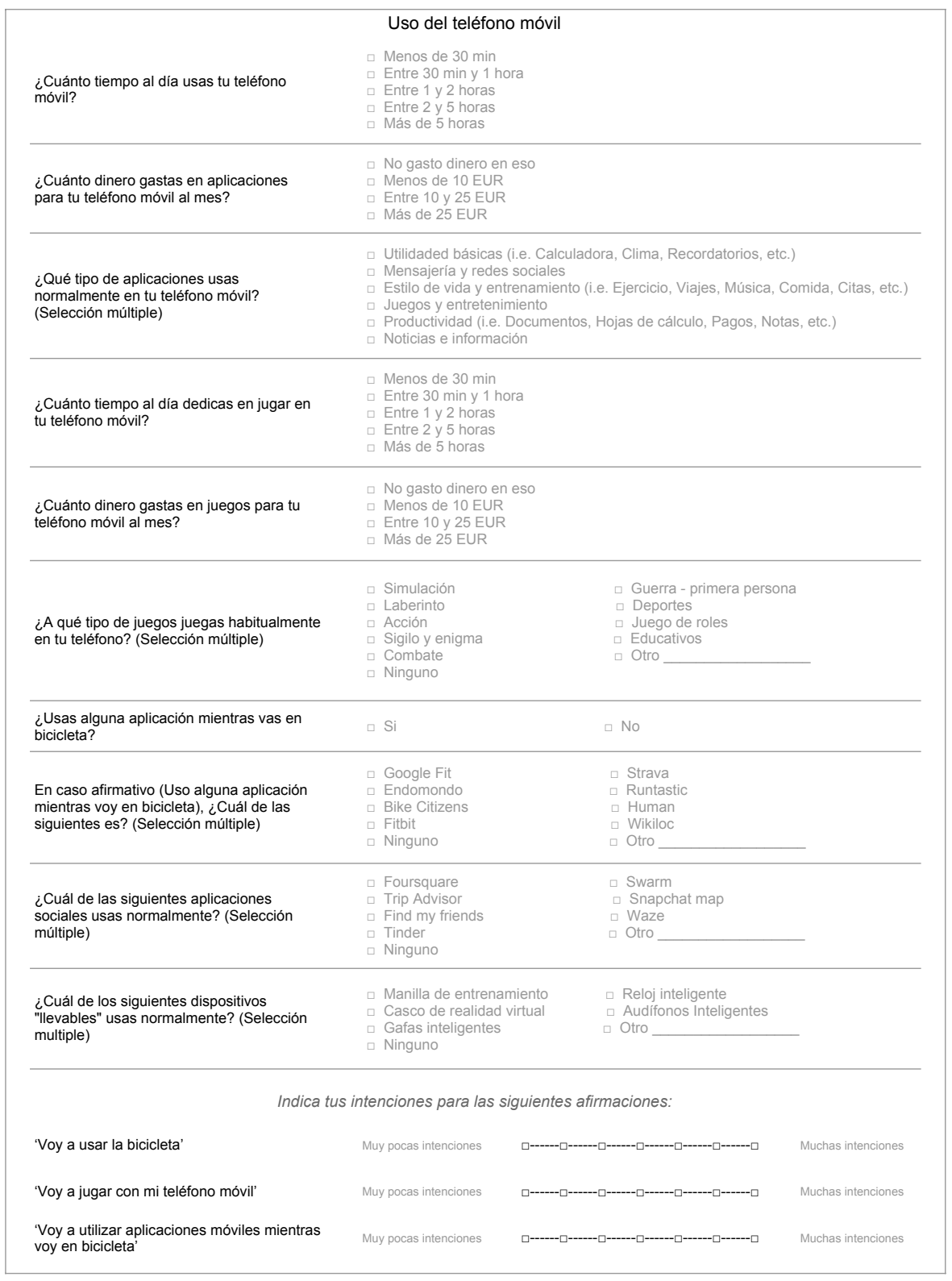




\begin{tabular}{|c|c|c|c|}
\hline \multicolumn{4}{|l|}{$\begin{array}{l}\text { UNIVERSITAT } \\
\text { JAUME I }\end{array}$} \\
\hline \multicolumn{4}{|c|}{ Indica tus intenciones para las siguientes afirmaciones: } \\
\hline 'Voy a usar la bicicleta' & $y$ pocas intenciones & 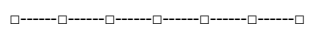 & Muchas intencione \\
\hline 'Voy a jugar con mi teléfono móvil' & y pocas intenciones & 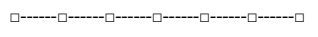 & Muchas intencione \\
\hline $\begin{array}{l}\text { 'Voy a utilizar aplicaciones móviles mientras } \\
\text { voy en bicicleta' }\end{array}$ & y pocas intenciones & 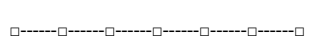 & Muchas intencione \\
\hline \multicolumn{4}{|c|}{ Indica en qué medida estás de acuerdo o en desacuerdo con las siguientes frases: } \\
\hline 'Iré en bicicleta en las próximas 2 semanas' & Totalmente en desacuerdo & 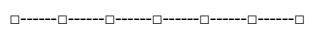 & Totalmente de acuerdo \\
\hline 'Iré en bicicleta en el futuro' & Totalmente en desacuerdo & 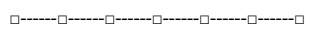 & Totalmente de acuerdo \\
\hline $\begin{array}{l}\text { 'Usaré la aplicación móvil del experimento } \\
\text { en las próximas } 2 \text { semanas' }\end{array}$ & Totalmente en desacuerdo & 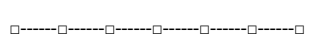 & Totalmente de acuerdo \\
\hline $\begin{array}{l}\text { 'Usaré la aplicación móvil del experimento } \\
\text { en el futuro' }\end{array}$ & Totalmente en desacuerdo & 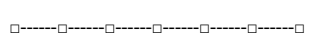 & Totalmente de acuerdo \\
\hline $\begin{array}{l}\text { 'Usaré una aplicación móvil mientras voy en } \\
\text { bicicleta en las próximas } 2 \text { semanas' }\end{array}$ & Totalmente en desacuerdo & 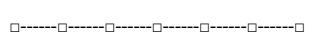 & Totalmente de acuerdo \\
\hline $\begin{array}{l}\text { 'Usaré una aplicación móvil mientras voy en } \\
\text { bicicleta en el futuro' }\end{array}$ & Totalmente en desacuerdo & 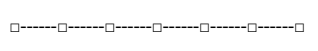 & Totalmente de acuerdo \\
\hline
\end{tabular}

Indica en qué medida estas de acuerdo o en desacuerdo con las siguientes frases:

\begin{tabular}{|c|c|c|c|}
\hline \multirow[b]{2}{*}{ Disfruto yendo en bicicleta } & \multirow{2}{*}{ Totalmente en desacuerdo } & \multirow{2}{*}{ 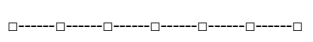 } & \multirow{2}{*}{ Totalmente de acuerdo } \\
\hline & & & \\
\hline Disfruto colaborando con otros ciclistas & Totalmente en desacuerdo & 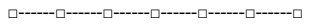 & Totalmente de acuerdo \\
\hline $\begin{array}{l}\text { Disfruto viendo mi contribución en la } \\
\text { aplicación }\end{array}$ & Totalmente en desacuerdo & 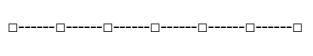 & Totalmente de acuerdo \\
\hline $\begin{array}{l}\text { Querria ver mi posiciòn en una tabla de } \\
\text { puntuaciones }\end{array}$ & Totalmente en desacuerdo & $-\square$ & Totalmente de acuerdo \\
\hline $\begin{array}{l}\text { La aplicación del experimento cumplió mis } \\
\text { expectativas }\end{array}$ & Totalmente en desacuerdo & $-\square$ & Totalmente de acuerdo \\
\hline $\begin{array}{l}\text { Creo que la aplicación del experimento es } \\
\text { fácil de usar }\end{array}$ & Totalmente en desacuerdo & 口-- & Totalmente de acuerdo \\
\hline \multicolumn{4}{|c|}{ Indica el nivel de satisfacción / insatisfacción general que tuviste al: } \\
\hline Ir en bicicleta durante el experimento & Muy insatisfecho & 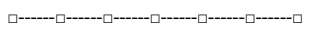 & Muy satisfecho \\
\hline Usar la aplicación del experimento & Muy insatisfecho & 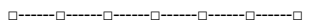 & Muy satisfecho \\
\hline
\end{tabular}

\begin{tabular}{l}
\hline Si tienes algún comentario o sugerencia, por favor escribelo a continuación \\
\hline \\
\hline
\end{tabular}




\section{HI UNIVESITAT}

Geด-ᄃ

\begin{tabular}{|c|c|c|c|}
\hline \multicolumn{4}{|c|}{ Feedback - CO-A } \\
\hline \multicolumn{4}{|c|}{ Indica tus intenciones para las siguientes afirmaciones: } \\
\hline 'Voy a usar la bicicleta' & Muy pocas intenciones & 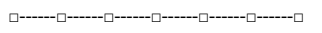 & Muchas intenciones \\
\hline 'Voy a jugar con mi teléfono móvil' & Muy pocas intenciones & 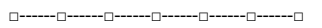 & Muchas intenciones \\
\hline $\begin{array}{l}\text { 'Voy a utilizar aplicaciones móviles mientras } \\
\text { voy en bicicleta' }\end{array}$ & Muy pocas intenciones & 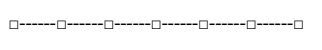 & Muchas intenciones \\
\hline \multicolumn{4}{|c|}{ Indica en qué medida estás de acuerdo o en desacuerdo con las siguientes frases: } \\
\hline 'Iré en bicicleta en las próximas 2 semanas' & Totalmente en desacuerdo & | & Totalmente de acuerdo \\
\hline 'Iré en bicicleta en el futuro' & Totalmente en desacuerdo & 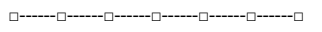 & Totalmente de acuerdo \\
\hline $\begin{array}{l}\text { 'Usaré la aplicación móvil del experimento } \\
\text { en las próximas } 2 \text { semanas' }\end{array}$ & Totalmente en desacuerdo & 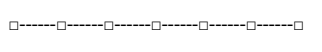 & Totalmente de acuerdo \\
\hline $\begin{array}{l}\text { 'Usaré la aplicación móvil del experimento } \\
\text { en el futuro' }\end{array}$ & Totalmente en desacuerdo & 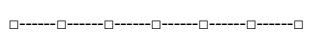 & Totalmente de acuerdo \\
\hline $\begin{array}{l}\text { 'Usaré una aplicación móvil mientras voy en } \\
\text { bicicleta en las próximas } 2 \text { semanas' }\end{array}$ & Totalmente en desacuerdo & 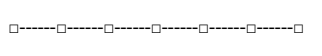 & Totalmente de acuerdo \\
\hline $\begin{array}{l}\text { 'Usaré una aplicación móvil mientras voy en } \\
\text { bicicleta en el futuro' }\end{array}$ & Totalmente en desacuerdo & 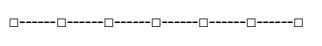 & Totalmente de acuerdo \\
\hline
\end{tabular}

Indica en qué medida estas de acuerdo o en desacuerdo con las siguientes frases:

Disfruto yendo en bicicle

Disfruto compitiendo con otros ciclistas

Totalmente en desacuerdo

Totalmente de acuerdo

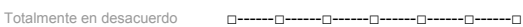

Totalmente de acuerdo

Disfruto viendo mi progreso en la aplicación

Disfruto viendo mi posición en el tabla de

puntuaciones

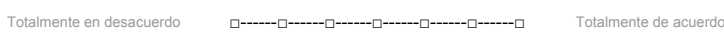

La aplicacion delexperimentocumplio mis

expectativas

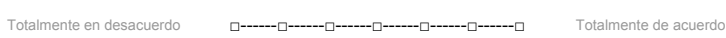

Creo que la aplicación del experimento es

fácil de usa

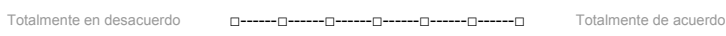

Totalmente en desacuerdo

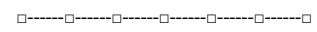

Totalmente de acuerdo

Indica el nivel de satisfacción / insatisfacción general que tuviste al:
Ir en bicicleta durante el experimento
Muy insatisfecho

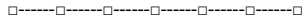
Muy satisfecho
Usar la aplicación del experimento
Muy insatisfecho

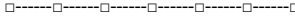
Muy satisfecho

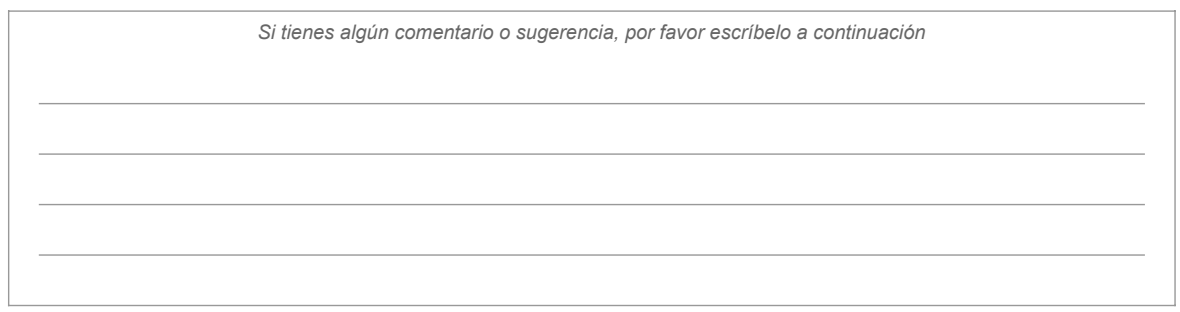

Retroalimentación - CO-B 



\section{Appendix C}

\section{Bicycle trips data structure}

This appendix describes the data structure of the trips data-set used during the identification of frictions inhibiting bicycle commuting.

\begin{tabular}{|c|c|c|}
\hline File & Field & Description \\
\hline \multirow[t]{2}{*}{ bikepaths_segments.geojson } & name & Bike path name \\
\hline & n_segments_in & Number of segments recorded in the bike path segment \\
\hline \multirow[t]{6}{*}{ bikepaths_trips.geojson } & name & Bike path name \\
\hline & n_trips_in & Number of trips recorded in the bike path segment \\
\hline & avg_speed_in & Average cycling speed recorded in the bike path segment \\
\hline & distance_in & Cycled distance in the bike path segment \\
\hline & distance & Distance of the the bike path segment \\
\hline & prop_cycled_distance & Cycled distance per metre of bike path \\
\hline \multirow[t]{7}{*}{ frictions.geojson } & n_grid_spots & Number of grid spots per friction \\
\hline & n_segments_l_5kmh & $\begin{array}{l}\text { Number of trip segments with speed between } 1 \text { to } 5 \mathrm{Km} / \mathrm{h} \\
\text { intersecting the friction area }\end{array}$ \\
\hline & intensity & Friction intensity estimated \\
\hline & n_trips & Number of trips intersecting the friction area \\
\hline & n_segments & Number of segments intersecting the friction area \\
\hline & city & City where the friction area is located \\
\hline & in_umz & 1 if the friction area is within the city \\
\hline \multirow[t]{5}{*}{ location.geojson } & time_gps & Timestamp of the record \\
\hline & device & Identification of the device recording data \\
\hline & altitude & Altitude of the location \\
\hline & speed & Participant speed when recording the trip \\
\hline & precision & precision of the measurement in metres \\
\hline \multirow[t]{6}{*}{ segments.geojson } & segment_count & Segment sequence number \\
\hline & device & Identification of the device recording data \\
\hline & trip_count & Trip identification \\
\hline & start_time & Time-stamp of the initial point \\
\hline & end_time & Time-stamp of the ending point \\
\hline & speed_geometry & Segment speed \\
\hline
\end{tabular}




\begin{tabular}{|c|c|c|}
\hline File & Field & Description \\
\hline & distance_geometry & Segment length in metres \\
\hline \multirow[t]{4}{*}{ trips_od.geojson } & device & Identification of the device recording data \\
\hline & trip_count & Trip identification \\
\hline & timestamp & Time-stamp of the record \\
\hline & type & Type of point \\
\hline \multirow[t]{13}{*}{ trips_tags.geojson } & device & Identification of the device recording data \\
\hline & trip_count & Trip identification \\
\hline & point_count & Number of points defining the trip \\
\hline & tag_1_text_en & Tag number one text \\
\hline & tag_1_category_en & Tag number one category \\
\hline & tag_1_polarity_en & Tag number one sentiment polarity \\
\hline & tag_2_text_en & Tag number two text \\
\hline & tag_2_category_en & Tag number two category \\
\hline & tag_2_polarity_en & Tag number two sentiment polarity \\
\hline & tag_3_text_en & Tag number three text \\
\hline & tag_3_category_en & Tag number three category \\
\hline & tag_3_polarity_en & Tag number three sentiment polarity \\
\hline & distance_geometry & Segment length in metres \\
\hline \multirow[t]{5}{*}{ Cyclist_Location.csv } & Device & Code identifying the user/device recording the location \\
\hline & Latitude & Location latitude in decimal degrees \\
\hline & Longitude & Location longitude in decimal degrees \\
\hline & Precision & $\begin{array}{l}\text { Location precision or accuracy of the location reported } \\
\text { by the device }\end{array}$ \\
\hline & time_gps & Recording time-stamp \\
\hline \multirow[t]{4}{*}{ Cyclist_Measurement.csv } & Device & $\begin{array}{l}\text { Code identifying the user/device recording the measure- } \\
\text { ment }\end{array}$ \\
\hline & Time_device & Recording time-stamp \\
\hline & Measurement & $\begin{array}{l}\text { Kind of measurement recorded: last recorded distance, } \\
\text { distance from the trip start, last recorded speed. The kind } \\
\text { of measurement defines the measurement units: metres } \\
(\mathrm{m}) \text { or metres per second (ms) }\end{array}$ \\
\hline & value & Measurement value \\
\hline \multirow[t]{8}{*}{ Cyclist_Trip.csv } & Device & Code identifying the user/device recording the trip \\
\hline & Trip_count & Number identifying the trip \\
\hline & Start_point.0 & Start point longitude \\
\hline & Start_point.1 & Start point latitude \\
\hline & End_latitude & End point latitude \\
\hline & End_longitude & End point longitude \\
\hline & Trip_start & Time when the trip started \\
\hline & Trip_stop & Time when the trip ended \\
\hline \multirow[t]{4}{*}{ Cyclist_Tag.csv } & Device & Code identifying the user/device recording the tag \\
\hline & Trip_count & $\begin{array}{l}\text { Number identifying the trip number associated with the } \\
\text { tag }\end{array}$ \\
\hline & Tag_count & Number identifying the tag \\
\hline & Text & Raw tag text \\
\hline
\end{tabular}




\section{Bibliography}

Abu-Sharkh, O. M. F. and Dabain, Z. (2016). GreenBikeNet: an Intelligent Mobile Application with Green Wireless Networking for Cycling in Smart Cities. Mobile Networks and Applications, 21(2):352-366.

Adrienko, N. and Adrienko, G. (2011). Spatial generalization and aggregation of massive movement data. IEEE Transactions on Visualization and Computer Graphics, 17(2):205-219.

Ahlqvist, O. and Schlieder, C. (2018). Geogames and geoplay : game-based approaches to the analysis of geo-information. Springer.

Albrecht, R., Väänänen, R., and Lokki, T. (2016). Guided by music: pedestrian and cyclist navigation with route and beacon guidance. Personal and Ubiquitous Computing, 20(1):121-145.

Armoogum, J. and Dill, J. (2015). Workshop Synthesis: Sampling Issues, Data Quality \& Data Protection. Transportation Research Procedia, 11:60-65.

Attard, M., Haklay, M., and Capineri, C. (2016). The Potential of Volunteered Geographic Information (VGI) in Future Transport Systems. Urban Planning, 1(4):6.

Ayuntament de Castelló (2016). PLAN DIRECTOR DE LA BICICLETA DE CASTELLÓN. Technical report, Ayuntament de Castelló, Castellón de la Plana.

Bagloee, S. A., Sarvi, M., and Wallace, M. (2016). Bicycle lane priority: Promoting bicycle as a green mode even in congested urban area. Transportation Research Part A: Policy and Practice, 87:102-121.

Barratt, P. (2017). Healthy competition: A qualitative study investigating persuasive technologies and the gamification of cycling. Health and Place, 46:328-336.

Basiri, A., Amirian, P., and Mooney, P. (2016). Using Crowdsourced Trajectories for Automated OSM Data Entry Approach. Sensors, 16(9):1510.

Bellotti, F., Berta, R., De Gloria, A., Dange, G., Paranthaman, P. K., Curatelli, F., Martinengo, C., Barabino, G., Sciutto, G., Demirtzis, E., and Hausler, F. (2016). A Smart Mobility Serious Game Concept and Business Development Study. In Games and Learning Alliance conference, volume 9221, pages 385-392.

Benitez-Paez, F., Comber, A., Trilles, S., and Huerta, J. (2018). Creating a conceptual framework to improve the re-usability of open geographic data in cities. Transactions in GIS, 22(3):806-822.

Berger, M. and Platzer, M. (2015). Field Evaluation of the Smartphone-based Travel Behaviour Data Collection App "SmartMo". Transportation Research Procedia, 11:263-279.

Berri, A. and Daziano, R. (2015). Workshop synthesis: Caring for the environment. Transportation Research Procedia, $11: 413-421$. 
Bigazzi, A. Y. (2017). Determination of active travel speed for minimum air pollution inhalation. International Journal of Sustainable Transportation, 11(3):221-229.

Birch, C. P., Oom, S. P., and Beecham, J. A. (2007). Rectangular and hexagonal grids used for observation, experiment and simulation in ecology. Ecological Modelling, 206(3-4):347-359.

Bleser, G., Steffen, D., Reiss, A., Weber, M., Hendeby, G., and Fradet, L. (2015). Personalized Physical Activity Monitoring Using Wearable Sensors. In Smart Health. Lecture Notes in Computer Science, volume 8700, pages 99-124.

Bonham, J. and Johnson, M. (2015). Cycling: Bringing the future into the present. In Burton, R., editor, Cycling futures, chapter 1, pages 3 - 23. Adelaide University Press, Adelaide.

Boss, D., Nelson, T., Winters, M., and Ferster, C. J. (2018). Using crowdsourced data to monitor change in spatial patterns of bicycle ridership. Journal of Transport \& Health, 9:226-233.

Boticki, I., Baksa, J., Seow, P., and Looi, C.-K. (2015). Usage of a mobile social learning platform with virtual badges in a primary school. Computers \& Education, 86:120-136.

Braun, L. M., Rodriguez, D. A., Cole-Hunter, T., Ambros, A., Donaire-Gonzalez, D., Jerrett, M., Mendez, M. A., Nieuwenhuijsen, M. J., and de Nazelle, A. (2016). Short-term planning and policy interventions to promote cycling in urban centers: Findings from a commute mode choice analysis in Barcelona, Spain. Transportation Research Part A: Policy and Practice, 89:164-183.

Broach, J., Dill, J., and Gliebe, J. (2012). Where do cyclists ride? A route choice model developed with revealed preference GPS data. Transportation Research Part A: Policy and Practice, 46(10):1730-1740.

Burke, J., Estrin, D., Hansen, M., Parker, A., Ramanathan, N., Reddy, S., and Srivastava, M. B. (2006). Participatory Sensing. In UCLA: Center for Embedded Network Sensing, editor, WSW'06 at SenSys '06, Boulder.

Butler, H., Daly, M., Doyle, A., Gillies, S., Schaub, T., and Schmidt, C. (2016). The GeoJSON format specification.

Calvey, J., Shackleton, J., Taylor, M., and Llewellyn, R. (2015). Engineering condition assessment of cycling infrastructure: Cyclists' perceptions of satisfaction and comfort. Transportation Research Part A: Policy and Practice, 78:134-143.

Campbell, K. B. and Brakewood, C. (2017). Sharing riders: How bikesharing impacts bus ridership in New York City. Transportation Research Part A: Policy and Practice, 100:264-282.

Carlsson, C. (2002). Critical mass : bicycling's defiant celebration. AK Press.

Castellanos, S. (2016). Delivering modal-shift incentives by using gamification and smartphones: A field study example in Bogota, Colombia. Case Studies on Transport Policy, 4(4):269-278.

Cervero, R., Sarmiento, O. L., Jacoby, E., Gomez, L. F., and Neiman, A. (2009). Influences of Built Environments on Walking and Cycling: Lessons from Bogotá. International Journal of Sustainable Transportation, 3(4):203-226.

Chen, P., Shen, Q., and Childress, S. (2018). A GPS data-based analysis of built environment influences on bicyclist route preferences. International Journal of Sustainable Transportation, 12(3):218-231.

Claudel, M., Nagel, T., and Ratti, C. (2015). From Origins to Destinations : The Past, Present and Future of Visualizing Flow Maps. Built Environment, 42(3):200.

Cohen-Blankshtain, G. and Rotem-Mindali, O. (2016). Key research themes on ICT and sustainable urban mobility. International Journal of Sustainable Transportation, 10(1):9-17.

Constantinidis, D. (2016). Crowdsourcing Culture: Challenges to Change. In Cultural Heritage in a Changing World, pages 215-234. Springer International Publishing, Cham. 
Coombes, E. and Jones, A. (2016). Gamification of active travel to school: A pilot evaluation of the Beat the Street physical activity intervention. Health \& Place, 39:62-69.

Dameri, R. P. and Benevolo, C. (2017). ICT Intensity in Smart Mobility Initiatives. In Smart City Implementation, pages 85-108. Springer International Publishing.

Degbelo, A., Bhattacharya, D., Granell, C., and Trilles, S. (2016a). Toolkits for smarter cities: A brief assessment. In García, C. R., Caballero-Gil, P., Burmester, M., and Quesada-Arencibia, A., editors, Lecture Notes in Computer Science (including subseries Lecture Notes in Artificial Intelligence and Lecture Notes in Bioinformatics), volume 10070 LNCS, pages 431-436. Springer, Cham.

Degbelo, A., Granell, C., Trilles, S., Bhattacharya, D., Casteleyn, S., and Kray, C. (2016b). Opening up Smart Cities: Citizen-Centric Challenges and Opportunities from GIScience. ISPRS International Journal of Geo-Information, 5(2):16.

Deterding, S., Dixon, D., Khaled, R., and Nacke, L. (2011). From game design elements to gamefulness. In Proceedings of the 15th International Academic MindTrek Conference on Envisioning Future Media Environments - MindTrek '11, page 9, New York, New York, USA. ACM Press.

Dill, J. and McNeil, N. (2012). FOUR TYPES OF CYCLISTS? Testing a Typology to Better Understand Bicycling Behavior and Potential.

Duarte, L. and Carriço, L. (2016). Designing for geo-referenced in-situ therapeutic scenarios. Information Systems Frontiers, 18(1):103-123.

Dutz, T., Hardy, S., Knöll, M., Göbel, S., and Steinmetz, R. (2014). User interfaces of mobile exergames. Lecture Notes in Computer Science (including subseries Lecture Notes in Artificial Intelligence and Lecture Notes in Bioinformatics), 8512 LNCS(PART 3):244-255.

easyMOBIZ mobile IT solutions (2017). SmartMo.

El Bastawisy, M., Reichardt, D., and Abdennadher, S. (2016). Towards a Human Machine Interface Concept for Performance Improvement of Cycling. In Games and Learning Alliance conference, volume 9221, pages 425-434.

Engineering and Technology (2016). Moves Driving Healthier Mobility.

European Cyclist Federation (2018). European mobility week.

European Environment Agency (2006). Urban morphological zones.

Fietsberaad Vlaanderen (2016). De FietsTelweek 2016.

Fishman, E., Washington, S., and Haworth, N. (2012). Barriers and facilitators to public bicycle scheme use: A qualitative approach. Transportation Research Part F: Traffic Psychology and Behaviour, 15(6):686-698.

Fishman, E., Washington, S., and Haworth, N. (2013). Bike Share: A Synthesis of the Literature. Transport Reviews, 33(2):148-165.

Flügel, S., Ramjerdi, F., Veisten, K., Killi, M., and Elvik, R. (2015). Valuation of Cycling Facilities with and without Controlling for Casualty Risk. International Journal of Sustainable Transportation, 9(5):364-376.

Fyhri, A., Heinen, E., Fearnley, N., and Sundfør, H. B. (2017). A push to cycling-exploring the e-bike's role in overcoming barriers to bicycle use with a survey and an intervention study. International Journal of Sustainable Transportation, 11(9):681-695. 
Garrard, J. (2015). Evaluating cycling promotion interventions. In Burton, R., editor, Cycling Futures, pages 429-452. University of Adelaide Press, Adelaide.

Gatersleben, B. and Haddad, H. (2010). Who is the typical bicyclist? Transportation Research Part F: Traffic Psychology and Behaviour, 13(1):41-48.

Gehan, E. A. (1965). A generalized Wilcoxon test for comparing arbitrarily singly-censored samples. Biometrika, 52(12):203-224.

Gong, L., Sato, H., Yamamoto, T., Miwa, T., and Morikawa, T. (2015). Identification of activity stop locations in GPS trajectories by density-based clustering method combined with support vector machines. Journal of Modern Transportation, 23(3):202-213.

Goodchild, M. F. (2007). Citizens as sensors: The world of volunteered geography. GeoJournal, 69(4):211-221.

Google Inc. (2017). Google Fit.

Google Inc. (2018). Google trends.

Gössling, S. (2018). ICT and transport behavior: A conceptual review. International Journal of Sustainable Transportation, 12(3):153-164.

Haklay, M. (2013). Citizen science and volunteered geographic information: Overview and typology of participation. In Crowdsourcing Geographic Knowledge: Volunteered Geographic Information (VGI) in Theory and Practice, volume 9789400745, pages 105-122. Springer Netherlands, Dordrecht.

Haklay, M. and Weber, P. (2008). OpenStreetMap: User-Generated Street Maps. IEEE Pervasive Computing, 7(4):12-18.

Halko, S. and Kientz, J. A. (2010). Personality and Persuasive Technology: An Exploratory Study on Health-Promoting Mobile Applications. volume 6137 of Lecture Notes in Computer Science, pages 150-161. Springer Berlin Heidelberg, Berlin, Heidelberg.

Handy, S., van Wee, B., and Kroesen, M. (2014). Promoting Cycling for Transport: Research Needs and Challenges. Transport Reviews, 34(1):4-24.

Hopkins, D. and Mandic, S. (2017). Perceptions of cycling among high school students and their parents. International Journal of Sustainable Transportation, 11(5):342-356.

Horton, D. (2006). Environmentalism and the bicycle. Environmental Politics, 15(1):41-58.

Huotari, K. and Hamari, J. (2012). Defining gamification. In Proceeding of the 16th International Academic MindTrek Conference on - MindTrek '12, page 17, New York, New York, USA. ACM Press.

ljaz, K., Wang, Y., Milne, D., and Calvo, R. A. (2016). Competitive vs Affiliative Design of Immersive VR Exergames. In Jcsg 2016, pages 140-150.

Iwińska, K., Blicharska, M., Pierotti, L., Tainio, M., and de Nazelle, A. (2018). Cycling in Warsaw, Poland - Perceived enablers and barriers according to cyclists and non-cyclists. Transportation Research Part A: Policy and Practice, 113:291-301.

Jacobsen, P. (2003). Safety in numbers: more walkers and bicyclists, safe walking and biking. Inj Prev, 9:205-209.

Kingham, S. and Tranter, P. (2015). Cycling and sustainable transport. In Bonham, J. and Johnson, M., editors, Cycling Futures, chapter 7, pages 131-152. The University of Adelaide Press. 
Koglin, T. and Rye, T. (2014). The marginalisation of bicycling in Modernist urban transport planning. Journal of Transport and Health, 1(4):214-222.

Küster, F. and Blondel, B. (2013). Calculating the economic benefits of cycling in EU-27. European Cyclists' Federation, pages 1-8.

Lakens, D. (2013). Calculating and reporting effect sizes to facilitate cumulative science: a practical primer for t-tests and ANOVAs. Frontiers in Psychology, 4:863.

Land Transport Authority (2013). Land Transport Master Plan.

Larsen, J., Patterson, Z., and El-Geneidy, A. (2013). Build It. But Where? The Use of Geographic Information Systems in Identifying Locations for New Cycling Infrastructure. International Journal of Sustainable Transportation, 7(4):299-317.

Leibetseder, A. and Lux, M. (2016). Gamifying fitness or fitnessifying games: A comparative study. CEUR Workshop Proceedings, 1642:37-44.

Leslie, E., Coffee, N., Frank, L., Owen, N., Bauman, A., and Hugo, G. (2007). Walkability of local communities: using geographic information systems to objectively assess relevant environmental attributes. Health \& place, 13(1):111-22.

Likert Rensis (1932). A technique for the measurement of attitudes. 22(144):55.

MacDonald, E. A., Case, N. A., Clayton, J. H., Hall, M. K., Heavner, M., Lalone, N., Patel, K. G., and Tapia, A. (2015). Aurorasaurus: A citizen science platform for viewing and reporting the aurora. Space Weather, 13(9):548-559.

Mapes, J. and Wolch, J. (2011). 'Living Green': The Promise and Pitfalls of New Sustainable Communities. Journal of Urban Design, 16(1):105-126.

Marchal, F., Hackney, J., and Axhausen, K. W. (1935). Speed and location observations from Global Positioning System Efficient Map Matching of Large Global Positioning System Data Sets Tests on Speed-Monitoring Experiment in Zürich. Technical report.

Matallaoui, A., Hanner, N., and Zarnekow, R. (2017). Introduction to Gamification: Foundation and Underlying Theories. In Gamification : Using Game Elements in Serious Contexts., chapter Chapter 1, pages 3-18.

McHugh, R., Bilous, R., Grant, C., and Hammersley, L. (2017). PACE at a Glance: Case Studies of the Student Experience. In Learning Through Community Engagement, pages 153-169. Springer Singapore, Singapore.

Médard de Chardon, C., Caruso, G., and Thomas, I. (2017). Bicycle sharing system 'success' determinants. Transportation Research Part A: Policy and Practice, 100:202-214.

Meier, S. (2015). Visualizing Large Spatial Time Series Data on Mobile Devices: Combining the HeatTile System with a Progressive Loading Approach. pages 161-173.

Meloni, I. and di Teulada, B. S. (2015). I-Pet Individual Persuasive Eco-travel Technology: A Tool for VTBC Program Implementation. Transportation Research Procedia, 11:422-433.

Miller, H. J. and Shaw, S.-L. (2001). Geographic Information Systems for Transportation: Principles and Applications. Oxford University Press.

Millonig, A. (2015). Challenged To Bike: Assessing the Potential Impact of Gamified Cycling Initiatives. pages 1-16.

Montini, L., Prost, S., Schrammel, J., Rieser-Schüssler, N., and Axhausen, K. W. (2015). Comparison of travel diaries generated from smartphone data and dedicated GPS devices. Transportation Research Procedia, 11:227-241.

Münster Stadt (2017). Bicyles in Münster. 
National Geospatial Advisory Committee (2015). THE CHANGING GEOSPATIAL LANDSCAPE A Second Look. National Geospatial Advisory Committee, (December):14.

Navarro, K. F., Gay, V., Golliard, L., Johnston, B., Leijdekkers, P., Vaughan, E., Wang, X., and Williams, M. A. (2013). SocialCycle: What can a mobile app do to encourage cycling? Proceedings - Conference on Local Computer Networks, LCN, pages 24-30.

Nelson, T. A., Denouden, T., Jestico, B., Laberee, K., and Winters, M. (2015). BikeMaps.org: A Global Tool for Collision and Near Miss Mapping. Frontiers in Public Health, 3:53.

Nicklas, D., Pfisterer, C., and Mitschang, B. (2001). Towards Location-based Games. In Proceedings of the International Conference on Applications and Development of Computer Games in the 21st Century: ADCOG 21, pages 61-67, Hongkong Special Administrative Region, China.

Nielsen, T. A. S., Skov-Petersen, H., and Agervig Carstensen, T. (2013). Urban planning practices for bikeable cities - the case of Copenhagen. Urban Research \& Practice, 6(1):110-115.

Norris, J. (2015). Future Trends in geospatial information management: the five to ten year vision. Technical report, United Nations Committee of Experts on Global Geospatial Information Management.

Nüst, D., Granell, C., Hofer, B., Konkol, M., Ostermann, F. O., Sileryte, R., and Cerutti, V. (2018). Reproducible research and GIScience: an evaluation using AGILE conference papers. PeerJ, 6:e5072.

OECD (2017). Functional urban areas by country.

Oldenziel, R., Emanuel, M., de la Bruheze, A. A. A., and Veraart, F. (2015). Cycling Cities: The European Experience. Foundation for the History of Technology and Rachel Carson Center for Environment and Society, Eindhoven.

op den Akker, H., Jones, V. M., and Hermens, H. J. (2014). Tailoring real-time physical activity coaching systems: a literature survey and model. User Modeling and User-Adapted Interaction, 24(5):351-392.

OpenStreetMap Contributors (2017). OpenStreetMap, Planet Dump.

Opromolla, A., Ingrosso, A., Volpi, V., Medaglia, C. M., Palatucci, M., and Pazzola, M. (2015). Gamification in a smart city context. An analysis and a proposal for its application in co-design processes. In Lecture Notes in Computer Science (including subseries Lecture Notes in Artificial Intelligence and Lecture Notes in Bioinformatics), volume 9221, pages 73-82.

Orellana, D. (2012). Exploring Pedestrian Movement Patterns. PhD thesis, Wageningen University.

Orellana, D. and Wachowicz, M. (2011). Exploring Patterns of Movement Suspension in Pedestrian Mobility. Geographical Analysis, 43(3):241-260.

Pajarito, D. and Gould, M. (2017a). Paper Survey Table - Smart Mobility - role of mobile games.

Pajarito, D. and Gould, M. (2017b). Smart Mobility, the Role of Mobile Games. In Lecture Notes in Computer Science, pages 44-59.

Pajarito, D. and Gould, M. (2018). Bicycle trips collected using Cyclists Geo-C geo-game.

Pajarito, D., Maas, S., Attard, M., and Gould, M. (2018). Mapping cyclists' routes: involving citizens in collecting open cycling data. In Mansourian, A., Pilesjö, P., Harrie, L., and von Lammeren, R., editors, Geospatial Technologies for All : short papers, posters and poster abstracts of the 21th AGILE Conference on Geographic Information Science. Lund University 12-15 June 2018, Lund, Sweden. 
Pang, B. and Lee, L. (2008). Opinion Mining and Sentiment Analysis. Foundations and Trends in Information Retrieval, 2(1-2):1-135.

Pardo, C. (2018). Sustainable mobility : getting people on board. Deutshe Gesellshaft Für Internationale Zusammenarbeit (GIZ).

Pejovic, V. and Musolesi, M. (2015). Anticipatory Mobile Computing. ACM Computing Surveys, 47(3):1-29.

People for Bikes (2017). People for Bikes.

Polar Electro (2018). Polar Explore map.

Pooley, C. G., Jones, T., Horton, D., Jopson, A., Mullen, C., Chisholm, A., and Constantine, S. (2011). Understanding walking and cycling: Summary of key findings and recommendations. Technical report, Lancaster Environment Centre, Lancaster University.

ProtoGeo Inc (2017). Moves.

Pucher, J. and Buehler, R. (2008). Making Cycling Irresistible: Lessons from The Netherlands, Denmark and Germany. Transport Reviews, 28(4):495-528.

Pucher, J. and Buehler, R. (2017). Cycling towards a more sustainable transport future. Transport Reviews, pages 1-6.

Pucher, J., Dill, J., and Handy, S. (2010). Infrastructure, programs, and policies to increase bicycling: An international review. Preventive Medicine, 50(SUPPL.).

Reddy, S., Shilton, K., Denisov, G., Cenizal, C., Estrin, D., and Srivastava, M. (2010). Biketastic: Sensing and Mapping for Better Biking. Proceedings of the SIGCHI Conference on Human Factors in Computing Systems, pages 1817-1820.

Revi, A., Satterthwaite, D. E., Arogón-Durand, F., Corfee-Morlot, J., Kiunsi, R., Pelling, M., Roberts, D., and Solecki, W. (2014). Urban areas. Climate Change 2014: Impacts, Adaptation, and Vulnerability. Part A: Global and Sectoral Aspects. Contribution of Working Group II to the Fifth Assessment Report of the Intergovernmental Panel on Climate Change, pages 535-612.

Rissel, C. (2015). Health benefits of cycling. In Bonham, J. and Johnson, M., editors, Cycling Futures, chapter 3, pages 43-62. The University of Adelaide Press.

Roche, S. (2014). Geographic Information Science: Why does a smart city need to be spatially enabled? Progress in Human Geography, 38(5):703-711.

Rodrigue, J.-P., Comtois, C., and Slack, B. (2013). The Geography of Transport Systems.

Roughton, C., van Hengel, D., Duncan, A., Weigand, L., and Birk, M. (2012). CREATING WALKABLE + BIKEABLE COMMUNITIES: A user guide to developing pedestrian and bicycle master plans. Technical report, Initiative for Bicycle and Pedestrian Innovation Center for Transportation Studies, Portland State University, Portland, OR.

Sainio, J., Westerholm, J., and Oksanen, J. (2015). Generating Heat Maps of Popular Routes Online from Massive Mobile Sports Tracking Application Data in Milliseconds While Respecting Privacy. ISPRS International Journal of Geo-Information, 4(4):1813-1826.

Schlieder, C., Kiefer, P., and Matyas, S. (2006). Geogames: Designing Location-Based Games from Classic Board Games. IEEE Intelligent Systems, 21(5):40-46.

Schrammel, J., Prost, S., Mattheiss, E., Bothos, E., and Tscheligi, M. (2015). Using individual and collaborative challenges in behavior change support systems: Findings from a two-month field trial of a trip planner application. In Lecture Notes in Computer Science (including subseries Lecture Notes in Artificial Intelligence and Lecture Notes in Bioinformatics), volume 9072, pages 160-171. 
Segadilha, A. B. P. and Sanches, S. d. P. (2014). Analysis of Bicycle Commuter Routes Using GPSs and GIS. Procedia Social and Behavioral Sciences, 162:198-207.

Shapiro, S. S. and Wilk, M. B. (1965). An Analysis of Variance Test for Normality (Complete Samples). Biometrika, 52(3/4):591.

Shin, D., Aliaga, D., Tunçer, B., Arisona, S. M., Kim, S., Zünd, D., and Schmitt, G. (2015). Urban sensing: Using smartphones for transportation mode classification. Computers, Environment and Urban Systems, 53:76-86.

Sileryte, R., Nourian, P., and van der Spek, S. (2016). Modelling Spatial Patterns of Outdoor Physical Activities Using Mobile Sports Tracking Application Data. pages 179-197.

Smith, M. E. (2015). Moving Towards a Greener Future : An Investigation of How Transit-Oriented Development Has the Potential to Redefine Cities Around Sustainability. Scripps senior theses, Claremont Graduate University.

Snizek, B., Sick Nielsen, T. A., and Skov-Petersen, H. (2013). Mapping bicyclists' experiences in Copenhagen. Journal of Transport Geography, 30:227-233.

Social Bicycles (2017). Social Cyclist.

Spillers, F. and Asimakopoulos, S. (2014). Does social user experience improve motivation for runners? a diary study comparing mobile health applications. Lecture Notes in Computer Science (including subseries Lecture Notes in Artificial Intelligence and Lecture Notes in Bioinformatics), 8520 LNCS(PART 4):358-369.

St-Louis, E., Manaugh, K., Van Lierop, D., and El-Geneidy, A. (2014). The happy commuter: A comparison of commuter satisfaction across modes. Transportation Research Part F: Traffic Psychology and Behaviour, 26(PART A):160-170.

Stein, C. (1945). A Two-Sample Test for a Linear Hypothesis Whose Power is Independent of the Variance. The Annals of Mathematical Statistics, 16(3):243-258.

Stieglitz, S. and Hassannia, S. (2016). Idea generation by employees and external participants in innovation competitions. Proceedings of the Annual Hawaii International Conference on System Sciences, 2016-March:4272-4281.

Stragier, J., Vanden Abeele, M., Mechant, P., and De Marez, L. (2016). Understanding persistence in the use of Online Fitness Communities: Comparing novice and experienced users. Computers in Human Behavior, 64:34-42.

Strava, I. (2018a). Global Heatmap.

Strava, I. (2018b). Strava.

Suh, A., Wagner, C., and Liu, L. (2015). The effects of game dynamics on user engagement in gamified systems. Proceedings of the Annual Hawaii International Conference on System Sciences, 2015-March:672-681.

Sultan, J., Ben-Haim, G., Haunert, J. H., and Dalyot, S. (2017). Extracting spatial patterns in bicycle routes from crowdsourced data. Transactions in GIS, 21(6):1321-1340.

Tabares, C. M. (2017). Individual factors related to utilitarian urban cycling : representations, motivations and perceived aggression. PhD thesis, Université Paris VIII —Vincennes-Saint-Denis.

Tang, J., Song, Y., Miller, H. J., and Zhou, X. (2016). Estimating the most likely space-time paths, dwell times and path uncertainties from vehicle trajectory data: A time geographic method. Transportation Research Part C: Emerging Technologies, 66:176-194.

te Brömmelstroet, M. (2014). Sometimes you want people to make the right choices for the right reasons: Potential perversity and jeopardy of behavioural change campaigns in the mobility domain. Journal of Transport Geography, 39:141-144. 
Tomitsch, M. and Haeusler, M. H. (2015). Infostructures: Towards a Complementary Approach for Solving Urban Challenges through Digital Technologies. Journal of Urban Technology, 22(3):37-53.

Topp, H. and Pharoah, T. (1994). Car-free city centres. Transportation, 21(3):231-247.

Torres, A., Sarmiento, O. L., Stauber, C., and Zarama, R. (2013). The Ciclovia and Cicloruta programs: promising interventions to promote physical activity and social capital in Bogotá, Colombia. American journal of public health, 103(2):e23-30.

Townsend, A. M. (2013). Smart cities : big data, civic hackers and the quest for a new utopia. Norton, New York:.

Tuveri, E., Macis, L., Sorrentino, F., Spano, L. D., and Scateni, R. (2016). Fitmersive Games : Fitness Gamification through Immersive VR. Proceedings of the International Working Conference on Advanced Visual Interfaces - AVI '16, pages 212-215.

Under Armour, I. (2018). Endomondo.

United Nations (2015). Sustainable Development Goals. Technical report, United Nations.

Urry, J., Leach, J., Dunn, N., and Coulton, C. (2017). The little book of car free cities. Lancaster University, Lancaster.

van Waes, A., Farla, J., Frenken, K., de Jong, J. P., and Raven, R. (2018). Business model innovation and socio-technical transitions. A new prospective framework with an application to bike sharing. Journal of Cleaner Production, 195:13001312.

Wall, S., Lee, D., Frangos, S., Sethi, M., Heyer, J., Ayoung-Chee, P., and DiMaggio, C. (2016). The Effect of Sharrows, Painted Bicycle Lanes and Physically Protected Paths on the Severity of Bicycle Injuries Caused by Motor Vehicles. Safety, 2(4):26.

Wang, H., Palm, M., Chen, C., Vogt, R., and Wang, Y. (2016). Does bicycle network level of traffic stress (LTS) explain bicycle travel behavior? Mixed results from an Oregon case study. Journal of Transport Geography, 57:8-18.

Weigend, A. (2017). Data for the People: How to Make Our Post-Privacy Economy Work for You. Hachette UK, Hachette UK.

Wikiloc Outdoor, S. (2018). Wikiloc.

Wojan, T. R. and Hamrick, K. S. (2015). Can Walking or Biking to Work Really Make a Difference? Compact Development, Observed Commuter Choice and Body Mass Index. PloS one, 10(7):e0130903.

Wolff, A., Valdez, A.-M., Barker, M., Potter, S., Gooch, D., Giles, E., and Miles, J. (2017). Engaging with the Smart City Through Urban Data Games. Gaming Media and Social Effects, pages 47-66. Springer Singapore, Singapore.

Wunsch, M., Stibe, A., Millonig, A., Seer, S., Chin, R. C., and Schechtner, K. (2016). Gamification and social dynamics: Insights from a corporate cycling campaign. In Streitz, N. and Markopoulos, P., editors, Lecture Notes in Computer Science (including subseries Lecture Notes in Artificial Intelligence and Lecture Notes in Bioinformatics), volume 9749 , chapter Distribute, pages 494-503. Toronto, ON, Canada,.

Xu, C., Yang, Y., Jin, S., Qu, Z., and Hou, L. (2016). Potential risk and its influencing factors for separated bicycle paths. Accident Analysis \& Prevention, 87:59-67.

Yang, Y., Heppenstall, A., Turner, A., and Comber, A. (2018). Examining the impact of new metro services on dockless bike sharing mobility patternse. In Mansourian, A., Pilesjö, P., Harrie, L., and von Lammeren, R., editors, Geospatial Technologies for All : short papers, posters and poster abstracts of the 21th AGILE Conference on Geographic Information Science. Lund University 12-15 June 2018, Lund, Sweden. 
Yeboah, G. and Alvanides, S. (2015). Route choice analysis of urban cycling behaviors using OpenStreetMap: evidence from a British urban environment. In OpenStreetMap in GIScience, number 9783319142791, pages 189-210. Springer, Cham.

Zahabi, S. A. H., Chang, A., Miranda-Moreno, L. F., and Patterson, Z. (2016). Exploring the link between the neighborhood typologies, bicycle infrastructure and commuting cycling over time and the potential impact on commuter GHG emissions. Transportation Research Part D: Transport and Environment, 47:89-103.

Zeile, P., Resch, B., Loidl, M., Petutschnig, A., and Dörrzapf, L. (2016). Urban Emotions and Cycling Experience enriching traffic planning for cyclists with human sensor data. GI_Forum, 1(2013):204-216.

Zhao, Z., Ali Etemad, S., Arya, A., and Whitehead, A. (2016). Usability and Motivational Effects of a Gamified Exercise and Fitness System Based on Wearable Devices. volume 9747 of Lecture Notes in Computer Science, pages 333-344. Springer International Publishing, Cham. 


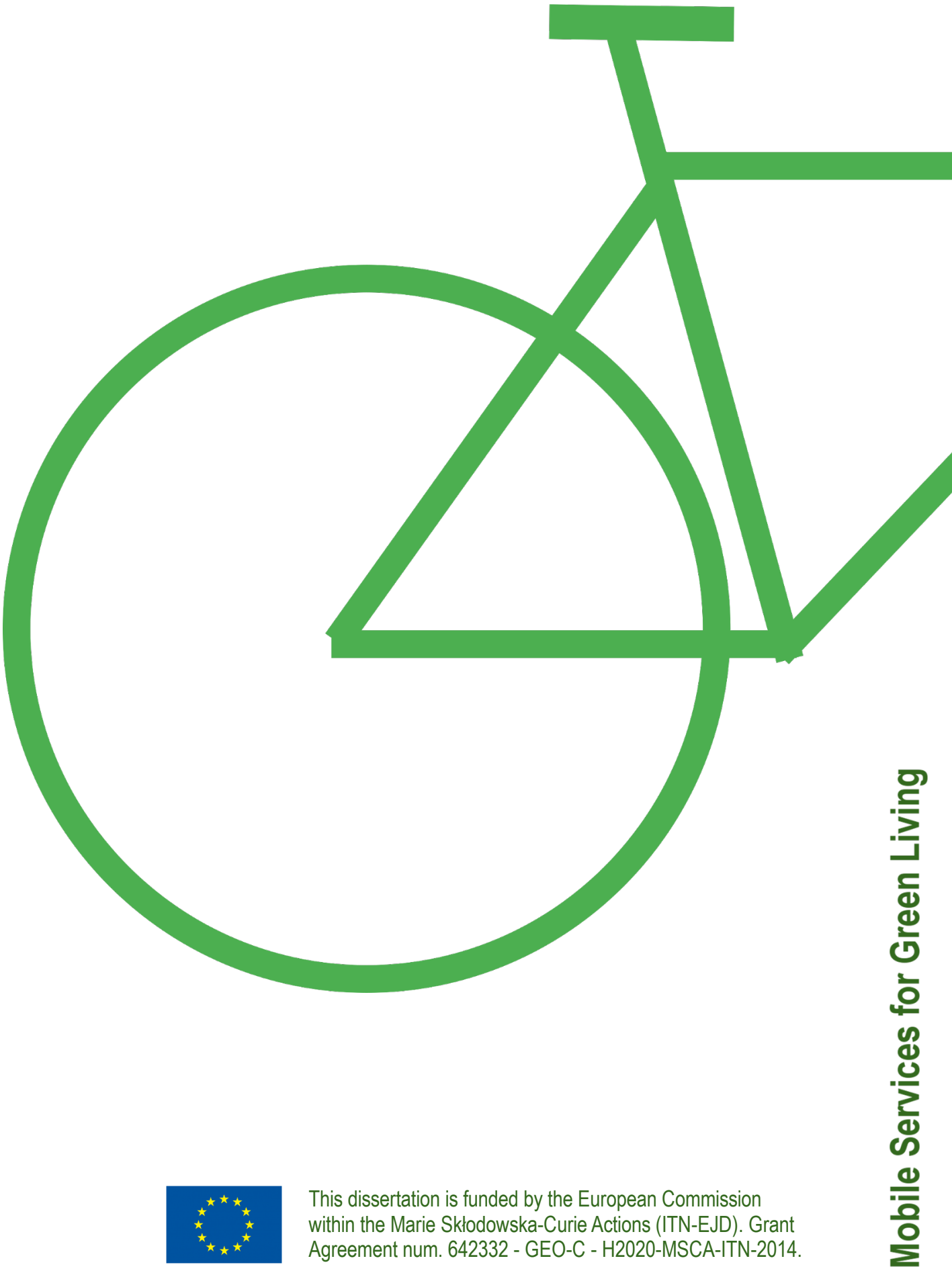

